I NTER NATIONAL MONETARY FUND

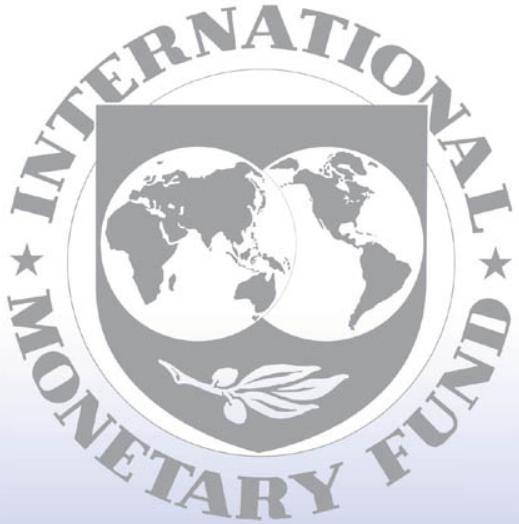

Staff

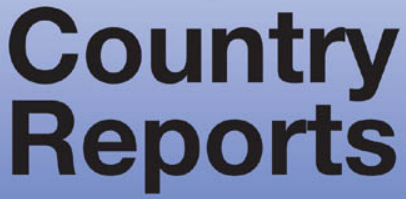




\section{People's Republic of China: 2005 Article IV Consultation-Staff Report; Staff Supplement;} and Public Information Notice on the Executive Board Discussion

Under Article IV of the IMF's Articles of Agreement, the IMF holds bilateral discussions with members, usually every year. In the context of the 2005 Article IV consultation with the People's Republic of China, the following documents have been released and are included in this package:

- the staff report for the 2005 Article IV consultation, prepared by a staff team of the IMF, following discussions that ended on May 25, 2005, with the officials of the People's Republic of China on economic developments and policies. Based on information available at the time of these discussions, the staff report was completed on July 8, 2005. The views expressed in the staff report are those of the staff team and do not necessarily reflect the views of the Executive Board of the IMF.

- a staff supplement of August 1, 2005 updating information on recent developments.

- $\quad$ a Public Information Notice (PIN) summarizing the views of the Executive Board as expressed during its August 3, 2005 discussion of the staff report that concluded the Article IV consultation.

The policy of publication of staff reports and other documents allows for the deletion of market-sensitive information.

To assist the IMF in evaluating the publication policy, reader comments are invited and may be sent by e-mail to publicationpolicy@imf.org.

Copies of this report are available to the public from

International Monetary Fund • Publication Services

$70019^{\text {th }}$ Street, N.W. • Washington, D.C. 20431

Telephone: (202) 623-7430 • Telefax: (202) 623-7201

E-mail: publications@imf.org • Internet: http://www.imf.org

Price: $\$ 15.00$ a copy

International Monetary Fund

Washington, D.C. 
This page intentionally left blank

CInternational Monetary Fund. Not for Redistribution 
INTERNATIONAL MONETARY FUND

PEOPLE'S REPUBLIC OF CHINA

Staff Report for the 2005 Article IV Consultation

Prepared by the Staff Representatives for

the 2005 Consultation with the People's Republic of China

Approved by David Burton and Carlos Muñiz

July 8,2005

- The 2005 Article IV discussions with China were held in Beijing, Shanghai, and Shenyang during May 11-25, 2005.

- The staff team comprised Mr. Dunaway (Head), Messrs. Aziz, Aitken, Feyzioğlu, and Wang (all APD), Ms. Fedelino (FAD), Mr. Bannister (ICM), Ms. Li (PDR), and Mr. Podpiera (MFD). The team was assisted by Mr. Brooks (Senior Resident Representative) and Mr. Barnett (Resident Representative). Mr. Xiaoyi Wang, Mr. Huarong Ge, and Mr.Wufu Zheng (OED) participated in the discussions. Mr. Kato joined the mission on May 23-24.

- China has accepted the obligations of Article VIII, Sections 2, 3, and 4 of the Articles of Agreement. Exchange controls continue to apply to most financial account transactions.

- While progress continues to be made in upgrading China's economic statistics, weaknesses remain in key areas. These include the national accounts, fiscal and labor statistics, the balance of payments, and the international investment position. The authorities are making improvements in all of these areas. China has participated in the GDDS, with its metadata posted on the official website (Dissemination Standards Bulletin Board) since April 2002.

- At the time of circulation, the Chinese authorities have not indicated whether they consent to the publication of the paper.

- The last Article IV consultation was concluded on July 28, 2004. At that time, Executive Directors noted that despite moderation in investment, a soft landing of the economy was not yet assured. They cautioned against a premature relaxation of monetary policy and stressed the need for fiscal policy to play a supportive role in achieving a soft landing. Directors reiterated that greater exchange rate flexibility was in China's best interest and noted that the initial move toward this objective was best made from a position of strength. They emphasized that continued structural reforms would be crucial for China to sustain strong growth over the medium term. Since the Article IV consultation, China has concentrated its efforts on reining in credit and investment growth, conducting monetary and fiscal policies broadly in line with the Board's recommendations. 
Table of Contents

I. Economic Developments and Outlook ……….............................................................. 4

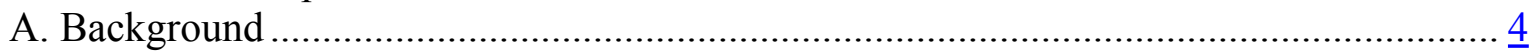

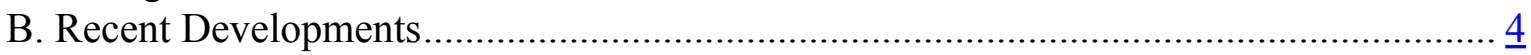

C. Macroeconomic Outlook and Risks ………………............................................ 10

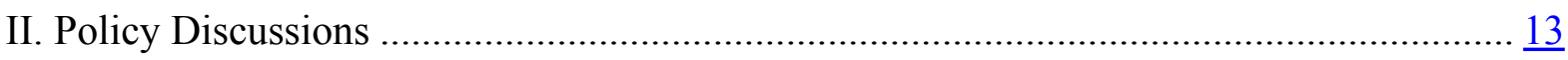

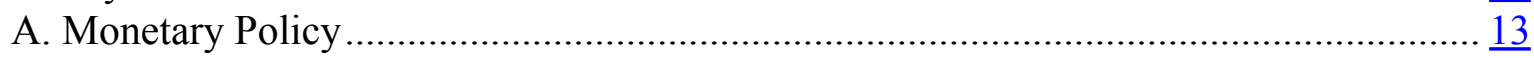

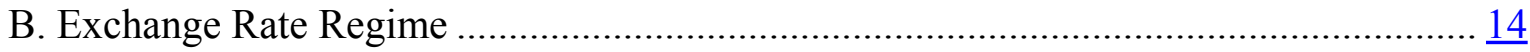

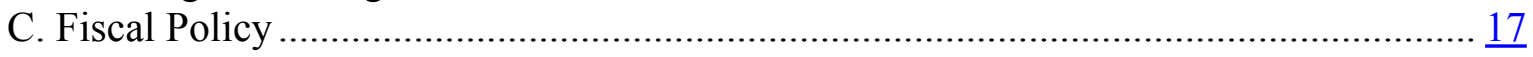

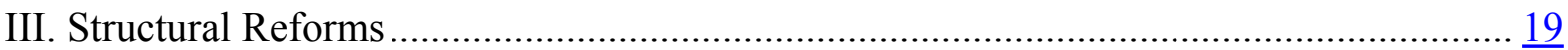

A. Banking and Capital Market Reforms ……………............................................... $\frac{19}{23}$

B. Reform of the State-Owned Enterprises..................................................................... $\frac{23}{23}$

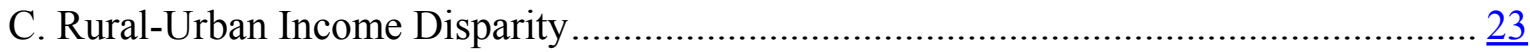

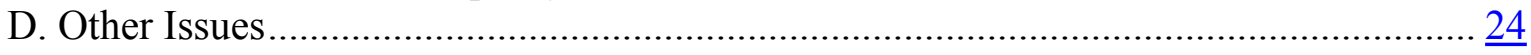

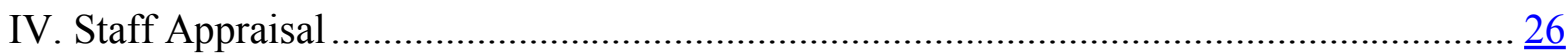

\section{Boxes}

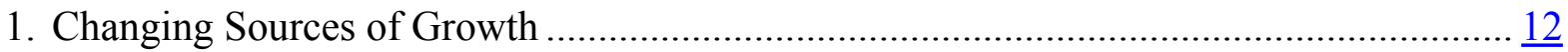

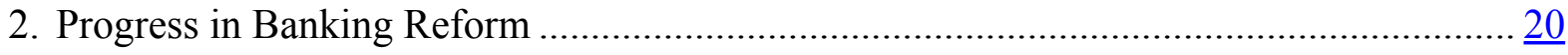

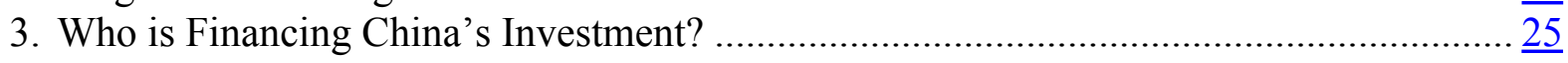

Tables

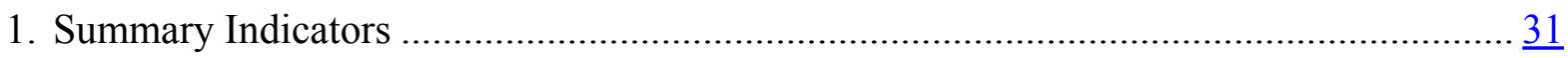

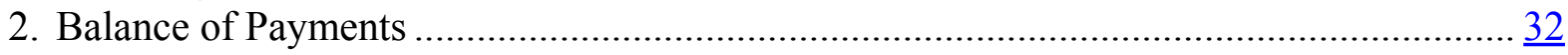

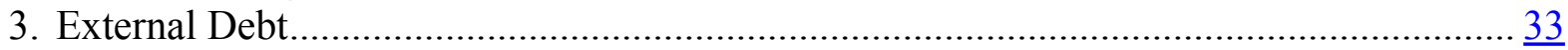

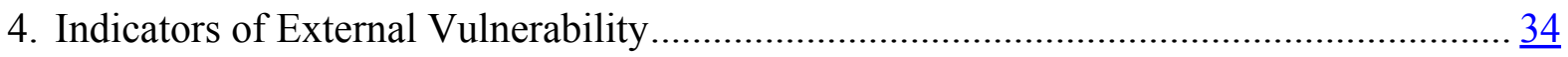

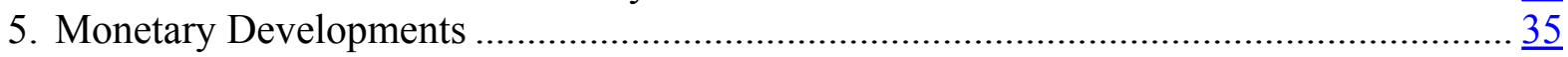

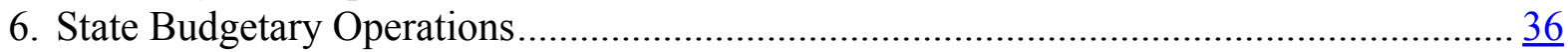

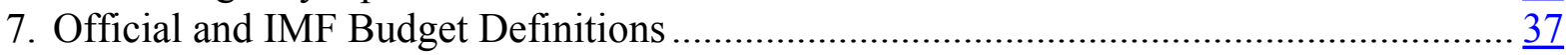

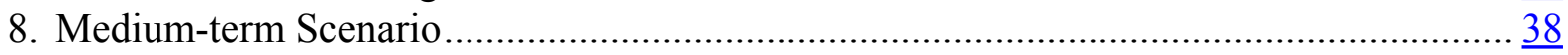

\section{Annexes}

I. Debt Sustainability Analysis ...................................................................................

II. China's Fiscal Reforms and Technical Assistance ……………………...................... 43

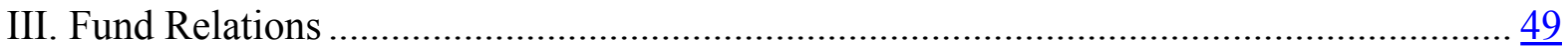

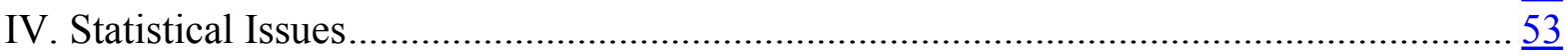

V. Relations with the World Bank ...................................................................................

VI. Relations with the Asian Development Bank ............................................................. $\frac{64}{66}$

VII. Millennium Development Goals ............................................................................... 66 


\section{EXECUTIVE SUMMARY}

\section{Economic Setting:}

Economic activity remained strong in $\mathbf{2 0 0 4}$ and the first four months of 2005. GDP growth stood at 9.5 percent in 2004 and 9.4 percent in Q1 2005, but its composition shifted as investment growth moderated somewhat and the contribution from net exports increased. Inflation declined, running at 1.8 percent in May, largely due to a reversal of food price increases. The external current account surplus rose to $4 \frac{1}{4}$ percent of GDP in 2004, and the trade balance strengthened further in the first five months of 2005. This, together with strong capital inflows, has led to a further large increase in foreign official reserves, which amounted to nearly $\$ 700$ billion at endMay.

During the course of 2004, the authorities tightened macroeconomic policies. The People's Bank of China (PBC) took several steps to tighten monetary conditions and slow lending growth. These measures have helped to slow the growth of broad monetary aggregates, but considerable liquidity remains in the banking system. The government also tightened administrative controls directed toward curbing investment growth in certain sectors. Strong revenue overperformance helped to bring down the fiscal deficit by 1 percentage point to $1 \frac{1}{2}$ percent of GDP.

\section{Policy Discussions:}

With the substantial liquidity in the banking system, the staff advised that open market operations should be intensified. The authorities also need to be prepared to tighten monetary conditions further using market-based instruments if investment and lending growth appears to be rebounding. The authorities agree about the need for containing investment growth, but consider administrative measures to be still needed for this purpose.

Greater exchange rate flexibility continues to be in China's best interest, and an early move would be desirable. It would give China more control over its monetary policy, and increase the economy's resilience to external and domestic shocks. Conditions at present are favorable for making an initial move, with further delay entailing additional costs to China's economy, which will grow over time. While agreeing with the need for more flexibility, the authorities are still considering the appropriate timing for making a first step in this direction.

The likely outturn for the 2005 budget is generally appropriate and in line with the objective of steadily bringing down the fiscal deficit over the medium term. Revenues should overperform once again this year, and any overperformance that accrues to the central government should be saved. The authorities regard the staff's revenue estimate to be optimistic, but are confident that at least the budgeted deficit target will be met.

On the structural reform agenda, bank reform should focus on strengthening the balance sheets of the state banks and improving their internal control systems, governance, and credit risk management. Reform of the state-owned enterprises, further development of financial markets, and improvements in economic statistics need to be carried forward. 


\section{ECONOMIC DEVELOPMENTS AND OUTLOOK}

\section{A. Background}

1. This year's discussions took place at a time when China's policymakers face significant challenges on the domestic front and growing international pressures.

Serious concerns emerged in the last two years that China's rapid rate of investment growth since early 2002 may be creating overinvestment in certain sectors. Coupled with a rise in inflation in 2004, this was seen as potentially fueling a more generalized overheating of the economy like the one in the early 1990s. The associated rapid growth in bank credit also raised the specter of substantial new nonperforming loans (NPLs) being created, adding to the large stock of

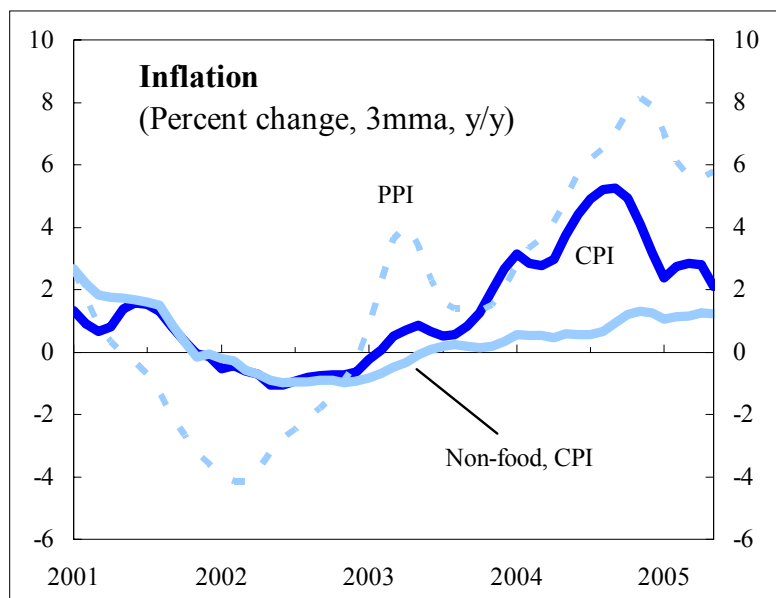
existing NPLs, much of which was created in the early 1990s. While a series of tightening measures have helped to slow the pace of investment growth, it remains high, and substantial liquidity remains in the banking system

\section{Since mid-2004, China's external position has strengthened further with} continued strong reserve accumulation. This has been perceived as pointing to increasing currency undervaluation and has focused international attention on China's contribution to global imbalances. Against this background, a sharp increase in textile exports to industrial countries after the expiration of MFA quotas at end-December 2004 has sparked increased protectionist pressures in some trading partner countries.

\section{B. Recent Developments}

3. At $91 / 2$ percent, GDP growth in 2004 was broadly the same as in 2003 , but its composition shifted modestly away from investment in the course of the year (Table 1). Investment growth moderated somewhat in response to stricter enforcement of administrative controls and tightening of monetary conditions directed at restraining its pace. Net exports increased its contribution to output growth, while consumption remained strong. Private consumption grew by nearly 8 percent, a faster pace than in 2003, supported to a large extent by rising rural income. Despite lay-offs of nearly $1 \frac{1}{2}$ million, due to the continued restructuring of state-owned enterprises, the urban unemployment rate edged down by 0.1 percentage point to 4.2 percent in 2004 , as job creation remained strong. 
4. Economic activity has maintained its momentum in the first five months of 2005. GDP in the first quarter grew at 9.4 percent rate (year-on-year), with the contribution from net exports increasing, as export growth remained strong and import growth moderated. Real fixed asset investment grew by around 23 percent, similar to the average level in 2004. Retail sales growth remained robust, suggesting continued strong consumer demand.

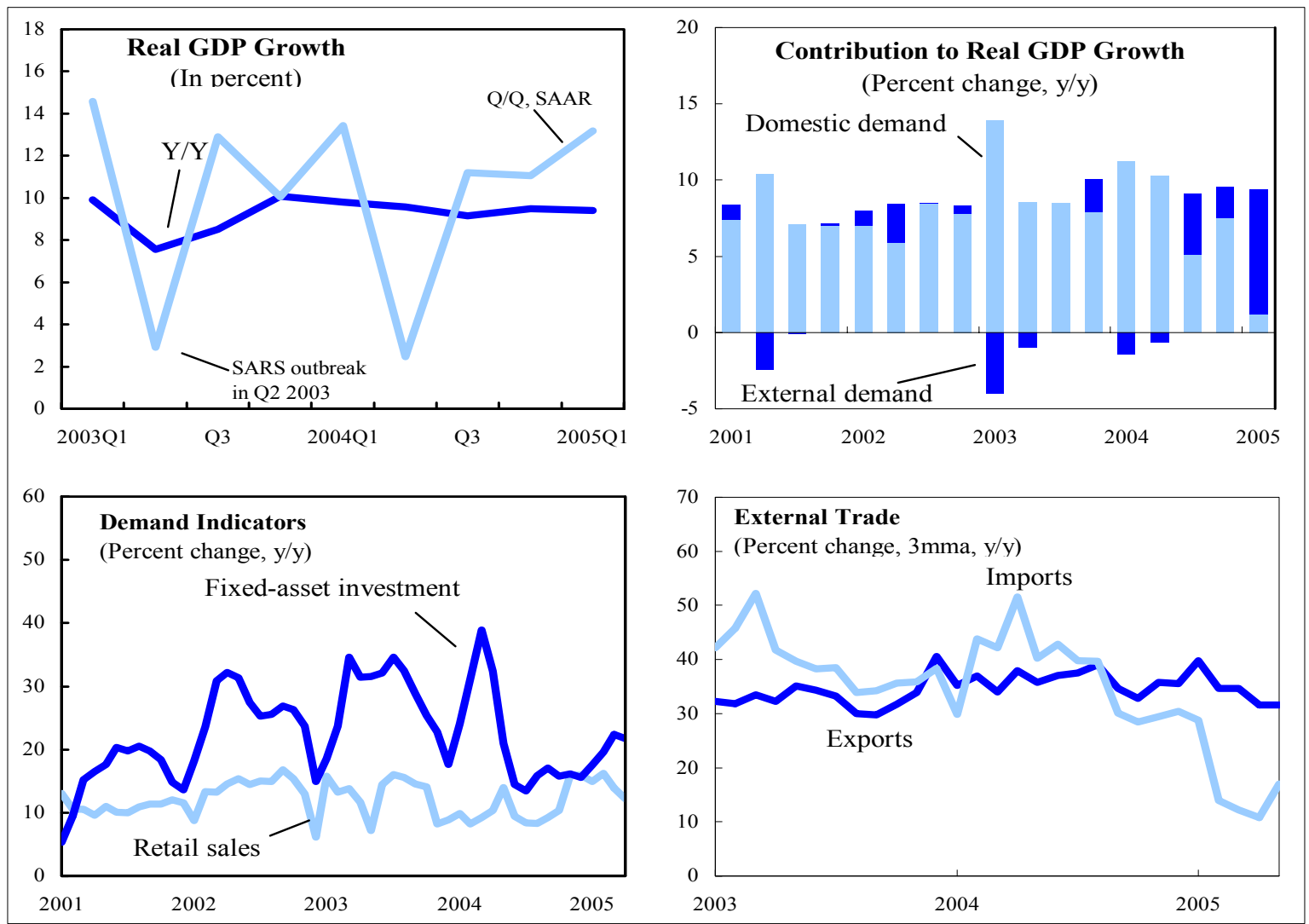

\section{Despite continued strong output} growth, inflation has come down. After peaking at 5 $\frac{1}{4}$ percent (year-on-year) in Q3 2004, headline CPI inflation fell sharply in late 2004, largely due to a reversal of food price increases as agricultural production rose. Supply-side factors - such as increased capacity from strong investment, persistent productivity gains, and reduction in tariffs - also served to kept non-food prices rises in check. Headline inflation remained

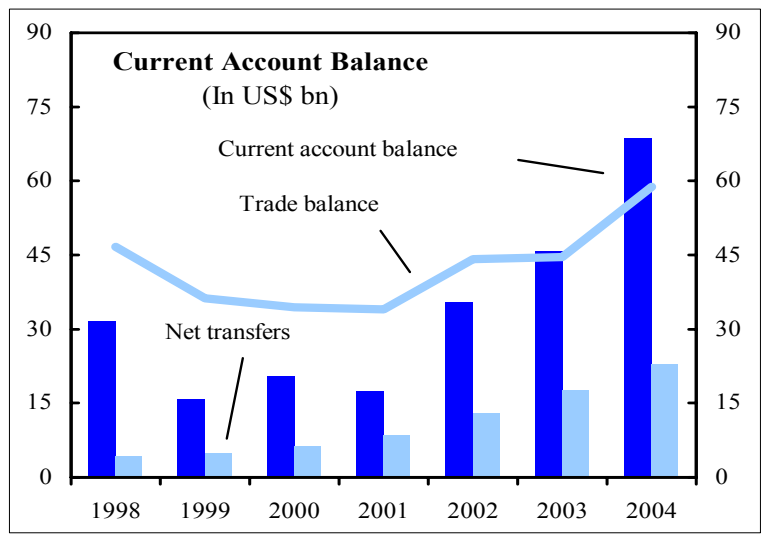


relatively subdued during the first five months of 2005, running at 13/4 percent (y/y) in May. After rising rapidly in the first part of 2004, PPI inflation has declined in recent months, reflecting some easing in world commodity prices and raw materials demand in China.

\section{The external current account surplus rose by 1 percentage point to $4 \frac{1}{4}$ percent}

of GDP in 2004. On the trade front, export growth remained strong throughout the year, but import growth slowed, particularly imports of raw materials and machinery and equipment, due to the moderation in investment growth and an increase in the supply of some domestic import substitutes. As a result, the trade surplus rose by 0.4 percentage point of GDP (Table 2). Private transfers also rose, probably reflecting speculative inflows in anticipation of a renminbi appreciation.

7. China's trade balance strengthened further in the first five months of 2005. In particular, the trade balance during January-May shifted to a sizeable surplus in contrast to the deficit registered in the same period of 2004. Exports during this period rose by 33 percent $(\mathrm{y} / \mathrm{y})$ while imports increased by only $13^{3 / 4}$ percent, mainly reflecting continued weak demand for raw materials and machinery and equipment. Chinese customs data suggest that total textiles exports grew at roughly the same rate as in 2004 (at an annual rate of around 20 percent), but importing country data indicate that the United States and the European Union registered a surge in textiles from China. The United States has imposed safeguards against textile imports from China, while the European Union has come to an agreement with the Chinese authorities to limit the growth of textile exports. ${ }^{1}$ National income accounts data suggest that the increase in the external current account surplus reflected rising domestic savings that exceeded investment. China's already high overall savings rate rose further to around 49 percent of GDP in 2004 fueled by strong corporate profits, with the contribution of retained earnings rising to close to half of the total. In contrast, household savings, although still high, are estimated to have declined relative to GDP in the last few years. ${ }^{2}$

${ }^{1}$ Textiles account for about 14 percent of Chinese exports. In the first four months of 2005 , textile exports from China to the United States (based on importing country data) jumped by 53 percent and to the EU by 71 percent. In response, the U.S. Department of Commerce re-imposed quotas on 7 categories of textile imports from China in May. In reaction, China revoked export taxes on about half of the textile items subject to this tax, which was originally introduced January 1, 2005. On June 10, the EU and China agreed to limit export growth of ten categories of textile exports from China to $8-12 \frac{1}{2}$ percent per year up to end-2007. Members of the U.S. Senate have proposed imposing a 271/2 percent import tariff on Chinese imports if the renminbi is not revalued by early October 2005.

${ }^{2}$ This decline is unlikely to be caused by the increase in corporate savings, as only a small part of the total enterprise equity is traded publicly in the stock market, and these shares are not widely held by individuals, directly or through institutional investors. 


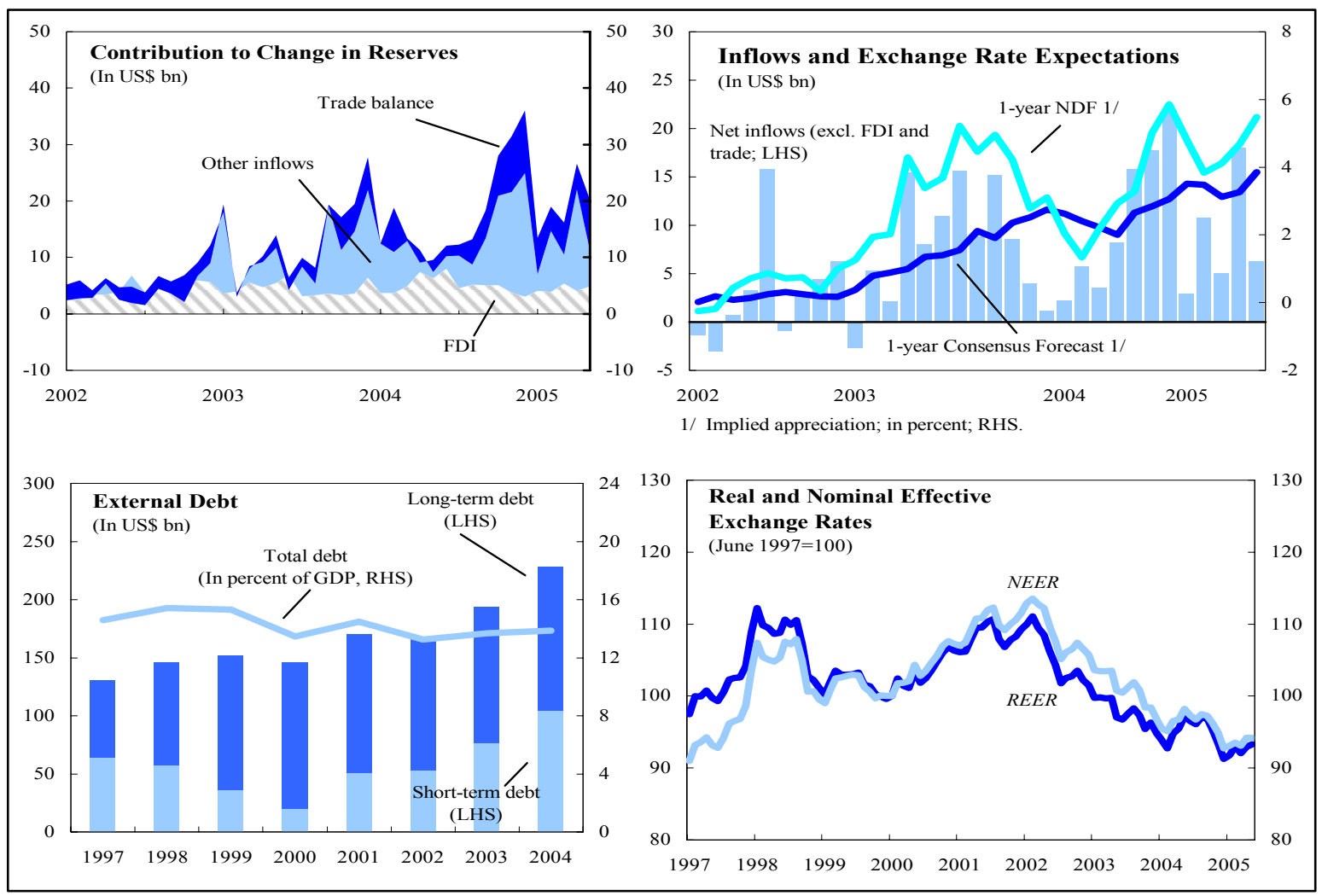

\section{The larger external current account surplus, together with strong capital} inflows, led to a further sizable increase in foreign official reserves (Tables 3 and 4). International reserves increased by $\$ 206$ billion in 2004 and by a further $\$ 81$ billion in the first five months of 2005, bringing the level at end-May to nearly $\$ 700$ billion. $^{3}$ While FDI inflows (mainly from Hong Kong SAR, Korea, and Japan) remained strong, a substantial portion of the reserve accumulation was accounted for by net non-FDI capital inflows (including errors and omissions) largely attracted by the prospects of a renminbi appreciation. The renminbi has depreciated in both real and nominal effective terms since mid-2004, and by end-April 2005, it was about 18 percent below its previous peak in February 2002.

\section{Real estate prices have continued to rise, with particularly large increases in} certain areas of fast-growing cities such as Shanghai. Some of the rise in housing prices is due to the cumulative impact of liberalization steps in land markets undertaken since 1998, but anecdotal evidence suggests that speculators are also quite active in the market.

\footnotetext{
${ }^{3}$ In late-April, $\$ 15$ billion of international reserves were used for the capital injection into the Industrial and Commercial bank of China (ICBC), reducing the end-April reserve level by that amount.
} 
Concerned with speculative pressures, the People's Bank of China (PBC) raised mortgage interest rates in March 2005. In May, the authorities also announced a new set of propertyrelated measures aimed at curbing speculation in residential and commercial markets. ${ }^{4}$ Despite the rise in real estate values, affordability indices have generally improved as household incomes have outpaced price increases.

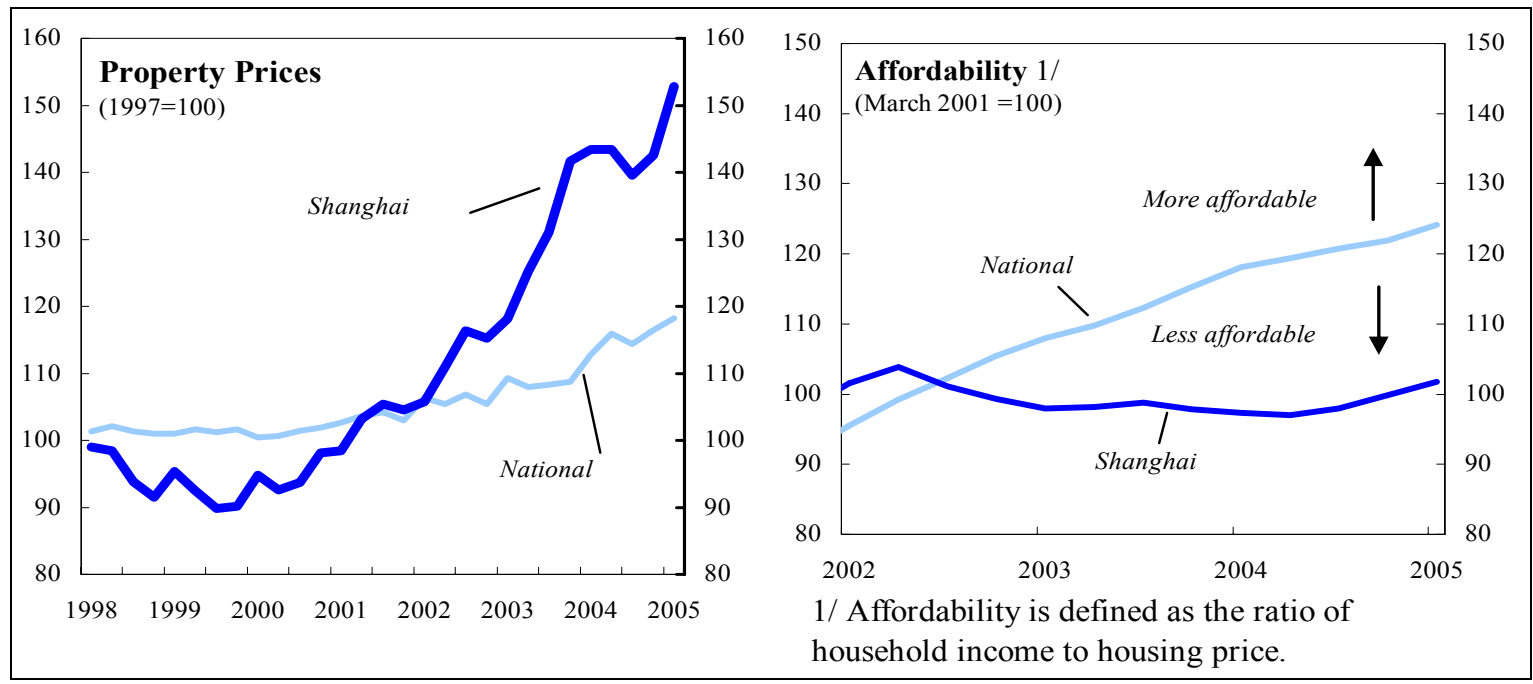

10. During the course of 2004, the PBC took several steps to reduce liquidity in the banking sector and slow lending growth. The steps taken included intensifying open market operations, raising the reserve requirement ratio and short-term re-lending and rediscount rates, increasing bank deposit and lending interest rates (for the first time in 9 years), and eliminating the ceiling on lending rates. These were supplemented with credit allocation guidance provided by the $\mathrm{PBC}$ and the China Bank Regulatory Commission (CBRC) to influence banks' lending decisions. These measures helped reduce broad money growth to 14 percent and loan growth to $12^{1 / 2}$ percent by April 2005, down by about $5 \frac{1}{2}$ and $8 \frac{1}{2}$ percentage points, respectively, from their growth rates in 2003 (Table 5).

\footnotetext{
${ }^{4}$ Some key elements of these measures are: (i) residential flats sold within two years of the initial purchase will be subject to a sales tax; (ii) developers who do not develop land within a year of purchase will face a tax penalty; (iii) land still idle after two years will be reclaimed by the government; (iv) resale of unfinished flats will be banned; and (v) commercial banks are required to tighten controls on lending to the property sector.
} 


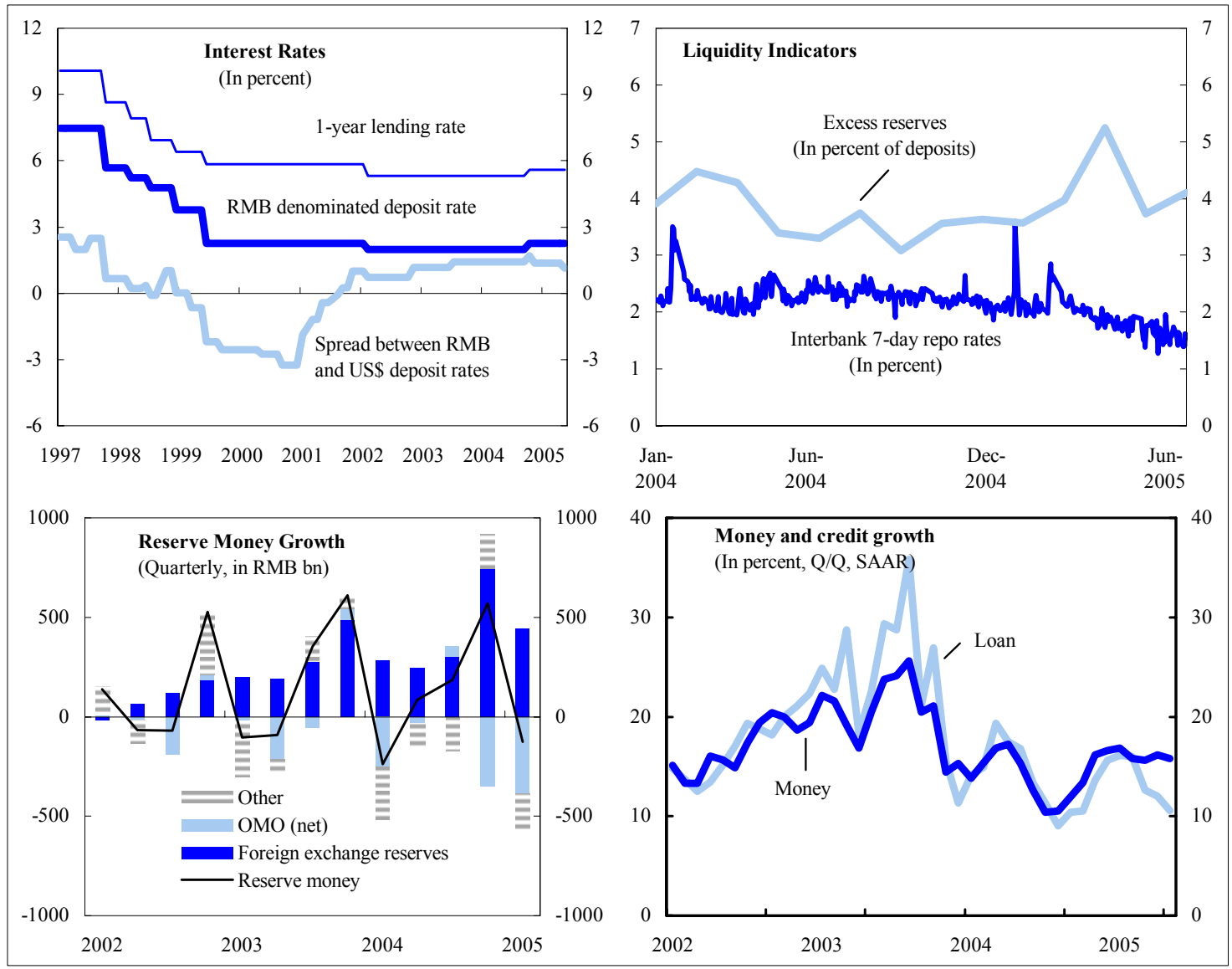

\section{Nevertheless, considerable liquidity remains in the system at present, as} evidenced by a still high excess reserve ratio and low interbank interest rates. In March 2005, the PBC cut the interest rate it pays on excess reserves held at the central bank, adding to downward pressures on interbank rates and reducing interest rates on central bank bills. The build-up in official reserves also continues to add substantially to liquidity. While the PBC stepped up its open market operations to sterilize most of the inflows beginning in late 2004, for the year as a whole only about half of the liquidity arising from the increase in international reserves was sterilized (as the trade surplus and capital inflows remained high). Overall, despite the liquidity in the banking system and some loosening of administrative controls, ${ }^{5}$ credit growth remains relatively constrained owing to continued lending guidance to banks provided by the PBC and the CBRC and restrained lending by the large state-owned banks (SCBs) that are undergoing restructuring.

${ }^{5}$ A key administrative measure, a six-month moratorium on converting agricultural land for property development, expired in October 2004. The authorities replaced this with other measures regulating land use, including encouraging land use rights auctions and tightening environmental protection standards. 


\section{Strong revenue overperformance allowed for a further decline in the fiscal}

deficit in 2004. The deficit fell to $1 \frac{1}{2}$ percent of GDP (official definition; $1 \frac{3}{4}$ percent according to the IMF definition; Tables 6 and 7), about one percentage point of GDP below its targeted level in the 2004 budget and the 2003 outcome. Once again, revenue was substantially above its budget projection by $1 \frac{3}{4}$ percentage points of GDP, reflecting strong activity and continued improvements in tax administration. About half of this revenue overperformance was used to finance increases in social expenditures and subsidies and to clear up old government liabilities, including arrears on VAT refunds to exporters. ${ }^{6}$ The remainder was unspent, partly because some transfers to local governments were made late in the year. During the first four months of 2005, gross revenue (excluding VAT refunds) grew by about 21 percent relative to the same period last year, compared with a budget forecast for 2005 of an 11 percent rise, while expenditure growth was broadly in line with the budget.

\section{Macroeconomic Outlook and Risks}

\section{Staff projects GDP growth to slow slightly during the year and to average} around 9 percent in 2005. This forecast assumes that appropriate macroeconomic policies will be in place to further slow investment growth. Export growth will remain strong, but slow from its current pace, with the growth in textile exports depending on the extent of safeguard measures imposed by China's trading partners. Import growth should pick up in the remainder of the year-with orders that were temporarily put on hold in anticipation of a currency appreciation brought on stream as inventories are depleted-but will remain below its 2004 level, reflecting slower investment growth. Consumption growth is expected to remain relatively strong as household credit facilities continue to expand and rural incomes rise further, reflecting cuts in rural taxes and government efforts to stabilize domestic grain prices. The external current account surplus would increase by nearly 2 percentage points to 6 percent of GDP, mainly reflecting a higher trade surplus. Inflation should average around 3 percent in 2005 . Slower food price increases are likely to be only partially offset by a rise in non-food prices as some of last year's rapid producer price increases is passed through to consumer prices and certain administered prices are raised. ${ }^{7}$

\section{A significant risk remains that macroeconomic policies will not be sufficiently}

tight to curb investment growth. In particular, there is a need for monetary policy to prevent a surge in credit growth as large capital inflows add liquidity to the banking system, increasing the odds of tipping off a boom-bust cycle and igniting inflationary pressures. Given the continuing volatility in world oil markets, a further sharp increase in oil prices would adversely affect growth both directly and indirectly if this leads to a more pronounced slowdown in global demand. Growing protectionist sentiments in China's major markets,

\footnotetext{
${ }^{6}$ Clearing of arrears - typically a below-the-line item - is treated as above-the-line expenditure in China's official fiscal accounts.

${ }^{7}$ Prices of utilities and other public services are slated to rise this year, after increases were postponed in 2004; however, there are prescribed limits to such increases.
} 
presents another key risk. Moreover, a disorderly unwinding of global imbalances would threaten China's growth, as economic activity in all countries would likely suffer lingering adverse effects.

\section{China's medium-term prospects are generally favorable provided near-term} risks are well managed and further structural reforms are implemented. The illustrative medium-term scenario presented in Table 8 suggests that GDP growth could average 7-8 percent annually, if structural reforms are advanced in the financial sector to improve intermediation of savings and in the state-owned enterprises and the labor market to maintain strong productivity growth. Fiscal reforms could also contribute to promote a more effective use of China's high domestic savings. Better financial intermediation and reforms to China's pension and health care systems would help to raise private consumption by further improving credit facilities and reducing the need for large precautionary savings. However, unless enterprise profits fall sharply or SOEs pay substantially more dividends to their shareholders (particularly the government), corporate retained earnings would remain high. Modest fiscal consolidation over the medium term, which is needed to ensure sustainability of public finances, will add to overall savings. With investment growth projected to decline, which is desirable and intended by current government policies, China's current account surplus would not be expected to narrow substantially in the medium term in the absence of a change in the real exchange rate. In particular, real appreciation would help raise consumption as households' purchasing power strengthened and renminbi prices of foreign goods declined. However, following convention, the real exchange rate is assumed to remain unchanged in the illustrative scenario presented here. In general, the extent of any change in the real exchange rate, the form that it might take (the relative contribution of changes in China's inflation rate versus changes in its nominal exchange rate), and the consequent impact on China's external balance are uncertain, depending to a large degree on the structural reforms that would be adopted in the medium term.

\section{Medium-term prospects are subject to significant risks. Growth could be} threatened in the years to come if China were to continue to rely heavily on investment as a primary source, especially if inefficient investment in some sectors leads to overcapacity and falling prices and profitability - as is already evident in the automobile industry, for example-burdening banks with additional NPLs in the coming years (Box 1). If reform of the domestic financial sector is not advanced substantially, vulnerabilities will continue to increase as China further integrates into the global economy, and capital account liberalization would expose the economy to potentially large swings in the direction of capital flows as household and corporations diversify their portfolios. If the expected change in the real exchange rate occurs through nominal exchange rate adjustment, inflation would remain modest. In the absence of adjustment in the nominal exchange rate, not only would the real exchange rate adjustment eventually take place through possibly much higher inflation, the economy would also need to unwind the likely large build-up of imbalances in resource allocation. Together these could have serious adverse effect on output. A rise in social stresses within China (if, for example, income gaps between the rural and urban areas increase substantially further) could also present a significant risk over the medium term. 


\section{Box 1. Changing Sources of Growth}

Investment in China has soared since the mid-1990s, while GDP growth—although still relatively highhas moderated from its pace in the late 1980s and early 1990s. At that time, investment was a lower share of GDP, so that productivity and employment growth contributed more to economic activity.

\section{A simple growth accounting exercise reveals a significant shift over time in the factors driving China's GDP growth away from total factor productivity (TFP) and employment growth to capital}

accumulation. As the charts illustrate, investment took over in the late 1990s and early 2000s as a dominant driver of growth. Over

this period the capital/output ratio and the capital/labor ratio have increased markedly, and while the investment to GDP ratio has risen sharply, the estimated marginal productivity of capital has fallen. TFP has continued to be a significant contributor to GDP growth, but its growth rate has declined. In contrast, employment growth has clearly become a less significant factor in explaining GDP growth. Although the growth in labor productivity has remained high, this is largely accounted for by rising capital intensity (a higher capital-labor ratio). Overall, the rise in
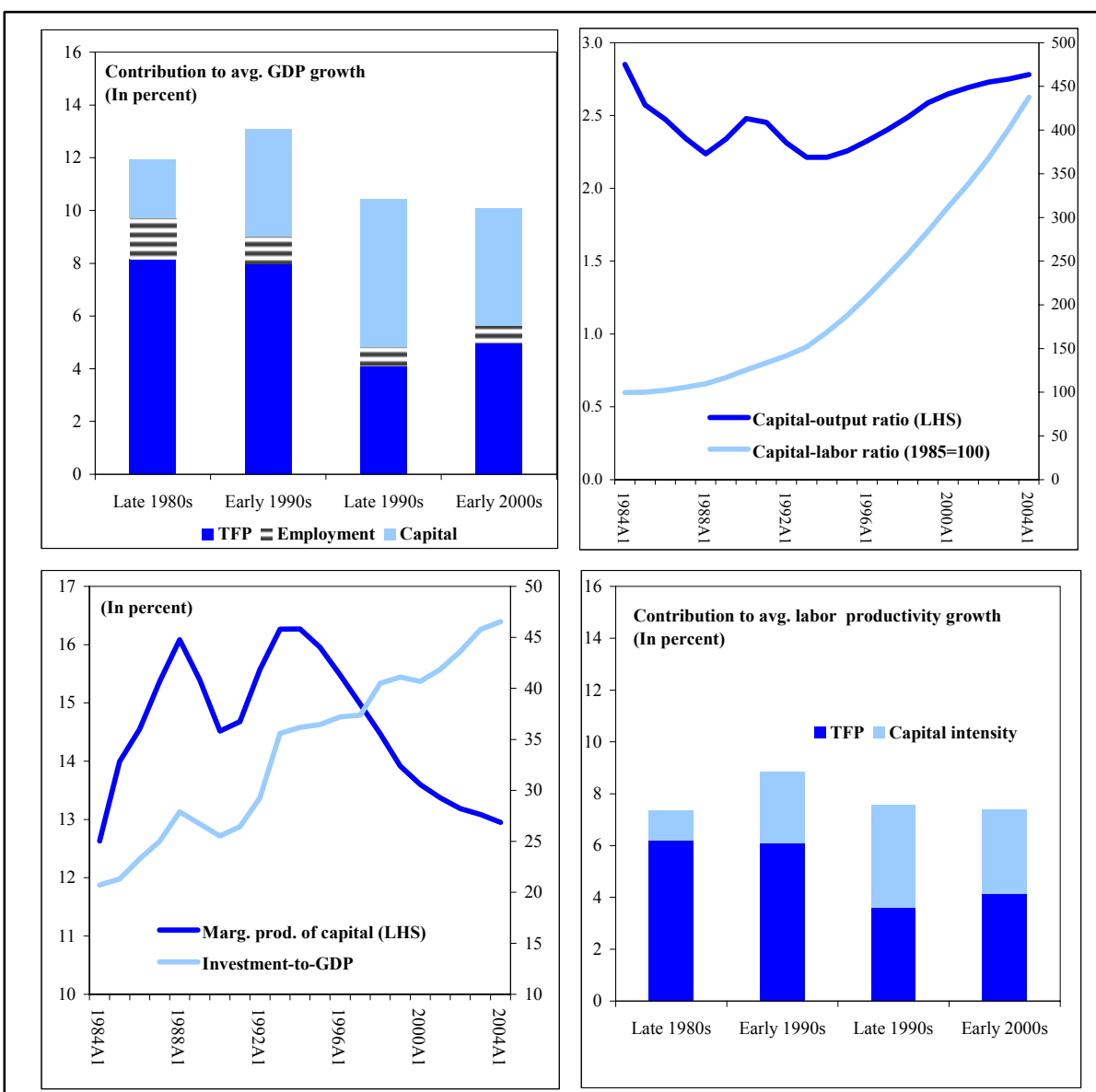

capital-intensive production and the low contribution of employment to growth in recent years is striking, given China's large number of underemployed workers. At the same time, the sustained fall in the marginal productivity of capital suggests that the efficiency of investment is increasingly declining.

A standard growth accounting framework is used for this analysis. Aggregate output is assumed to be produced using a Cobb-Douglas production function: $Y=A K^{\alpha} N^{1-\alpha}$, where $Y$ is aggregate output, $A$ is total factor productivity, $K$ is the capital stock, and $N$ is total hours worked. Aggregate output is measured by GDP. The capital stock is constructed using a perpetual inventory method, assuming an initial (1965) stock and a physical depreciation rate of 0.06 that is based on the structure of fixed asset investment and industry surveys of depreciation costs. $N$ is approximated by the total number of employed workers. The elasticity of capital, $\alpha$, is set at 0.36 , as is standard in the literature. $A$ is derived as a residual. While the relative contributions to GDP growth of the three principal factors affecting production may change somewhat with small changes in feasible ranges in assumptions for key parameters, the basic trends in the data over time remain the same. 


\section{Policy Discussions}

17. The authorities agreed with the general economic outlook presented by the staff. They noted that inflation remained moderate and economic measures already taken had slowed investment growth significantly from its peak in the first half of 2004, and they pointed to the risk that excess liquidity in the banking system and strong local government incentives to invest could lead to a rebound in investment and bank lending growth. On the external front, the authorities recognized the risks of a more pronounced slowdown in global demand, and they were especially concerned by a rise in protectionist pressures in some major trading partners. Against this background, the discussions focused on: further steps that may need to be taken to constrain investment growth and keep inflationary pressures in check; the likelihood that speculative inflows will continue to complicate monetary policy; the need for an early move toward greater exchange rate flexibility; the scope for further budget consolidation given an expectation of continued strong revenue overperformance; and the structural reform agenda, including in particular financial market reform to substantially improve the intermediation of China's large domestic savings.

\section{A. Monetary Policy}

18. The authorities recognize the need to contain investment and credit growth. Monetary and credit aggregates have grown roughly in line with their annual targets, but the restrained growth of the monetary aggregates - despite the abundant liquidity held by banks - appears largely due to administrative measures and more cautious lending by the state-owned banks undergoing restructuring. The staff cautioned that the substantial liquidity in the banking system carried with it a risk of triggering a rebound in lending growth, and thus, it suggested that the PBC should intensify open market operations to drain more of this liquidity.

\section{Beyond more intense open market operations, the authorities need to be} prepared to tighten monetary policy further. If investment and lending growth appeared to be rebounding, the staff recommended that stepped-up open market operations be supplemented with increases in interest rates and reserve requirements. Staff also argued that monetary tightening measures could be complemented, if needed, by further strengthening of prudential rules relating to bank asset quality, such as guidance on bank lending standards, provisioning requirements, and concentration limits. In addition to enhancing overall financial stability, these steps would help curb near-term credit growth. The authorities acknowledged that further policy tightening might be needed if investment and credit growth were to rebound. While they favored making use of market-based monetary policy instruments, the authorities pointed out that administrative measures would still be needed, as these were better suited to restrain growth in the specific sectors where overinvestment was a particular concern. Staff agreed that some administrative measures might be needed, but favored measures that would enhance supervision of bank lending to vulnerable sectors. 
20. The staff discussed ways to improve the effectiveness of indirect monetary policy instruments to manage the economy better. The effectiveness of monetary instruments depends on the timeliness of policy actions. Accordingly, the staff urged the authorities to consider granting the PBC more discretion to independently set interest rates. While recognizing that interest rate changes are a national concern and that consultations within the government could be beneficial in building support for a change, staff cautioned that policy action could be unduly delayed. Moreover, reliance on administrative means of control, while necessary at present, will have to diminish as the increasing sophistication of the economy reduces their effectiveness and raises the cost of the distortions that they create. As a transitional arrangement, staff suggested that consideration be given to granting the PBC the authority to set benchmark interest rates at least within a specified range.

\section{B. Exchange Rate Regime}

\section{The staff reiterated the arguments for greater exchange rate flexibility in China,} emphasizing that an early move is warranted. Staff noted that greater flexibility is in China's best interest, as it would help in strengthening macroeconomic control by increasing the scope for pursuing an independent monetary policy and the ability of the economy to adjust to shocks. A phased approach in moving to full flexibility was recommended to limit disruption to the domestic economy, especially since currency risk management instruments are underdeveloped. While recognizing that the authorities are best positioned to decide on the precise timing of a change, the staff stressed that conditions at present were favorable for making an initial move, given that the economy is currently quite strong and that there are no major impediments in foreign exchange and financial markets to doing so. The economic costs of maintaining the current regime have been evident over the past year, and continue to mount, suggesting an early move is warranted. Although it is difficult to reach firm conclusions about its extent, the continued strengthening of the external balance points to increased undervaluation of the renminbi, adding to the urgency of making a move.

\section{Further delay in moving toward greater exchange rate flexibility would entail} additional costs to China's economy. The staff pointed out that under the current fixed exchange rate, adjustment in China's economy to growing external surpluses was taking place, but in ways that may be creating serious distortions and potential vulnerabilities for the economy. In particular, delay in making a change in the exchange rate regime would likely continue to create visible problems in the form of a further large build-up in reserves and growing difficulties in sterilizing capital inflows. This situation also runs the risk that the PBC's ability to conduct monetary policy could be compromised, particularly if concerns about the impact on the central bank's income position constrained decisions on interest rate increases. Less visible would be a likely build-up of short-term foreign currency liabilities, as Chinese firms find it increasingly attractive over time to borrow funds offshore, substantially raising the economy's external vulnerability. Investment decisions across the economy would also continue to be distorted, with resources allocated to projects in the traded goods sector than may not be viable over the medium term. Consequentially, the economic costs of delaying a move might be growing faster than is currently evident. The staff also raised concerns about rising protectionist pressures and the growing possibility of a disorderly 
resolution of global external imbalances, which would have lingering adverse effects on all countries.

23. The authorities broadly shared the staff's views on the advantages of increased exchange rate flexibility over the medium term, but noted that a consensus on the timing of a move had not yet been reached. ${ }^{8}$ They underscored that significant progress has been made in preparing for a move to greater exchange rate flexibility. The authorities, however, stressed that their key concern continues to be the potential adverse impact of a change in the exchange rate on macroeconomic and financial sector stability. Some officials also felt that China should not move on the exchange rate until the banking system was reformed. In addition, the authorities considered the current regime and the level of the exchange rate to have served regional and global economies well, and that there was no convincing evidence pointing to the undervaluation of the renminbi-a view supported by some international analysts. Concerns were also expressed that growth and employmentparticularly in the agricultural sector - could falter if a large and unwarranted appreciation follows the exchange rate regime change, with potentially serious implications for social stability. At the same time, the authorities stated that a resolution to the problem of global imbalances required a concerted effort by all major countries, led first by credible action in the United States to reduce its fiscal deficit and increase national savings. While acknowledging that China had a role to play, they stressed that China alone could not solve this problem. They noted that growing protectionism against Chinese exports and stepped-up international pressures for an exchange rate change have complicated the decision-making process.

24. Responding to the authorities' concerns about the impact on China's economy, the staff argued that the effects on growth and employment of an initial change in the exchange rate were likely to be moderate. The impact would vary across sectors of the economy and across regions, but the overall impact of an initial move would not be large, ${ }^{9}$ and could be managed - especially in an economy that has considerable underlying strength in activity - with some easing of macroeconomic policies or other policy adjustments. In this regard, if rural income were a particular area of concern, the staff noted that it would be better to address any difficulties caused by an exchange rate change-which were likely to be limited - through fiscal transfers to affected households than by delaying a move in the rate. In the commercial banking sector, the direct effects of a likely exchange rate change should be small, with exposure to foreign currency risk relatively low. Indirect effects

\footnotetext{
${ }^{8}$ Subsequent to the consultation discussions, Premier Wen Jiabao in a public speech on June 26, 2005 stressed that, the authorities' objective was to "gradually establish a market-based and well-managed floating exchange rate system." To meet this objective, steps would be taken based on "the principles of independent initiative, controllability, and gradual progress to independently determine the modality, content, and timing of the reform in accordance with China's needs for reform and development."

${ }^{9}$ The staff's analysis is presented in the Selected Issues paper.
} 
through the impact on bank customers also should not be significant. The net impact on the corporate sector would likely be positive, as the value of foreign currency debt would decline and balance sheets would improve, although customers in the export sector may suffer somewhat. Staff also noted that greater exchange rate flexibility has preceded capital account liberalization in many advanced and developing countries, and that, in fact, experience suggests that it is advantageous to have increased exchange rate flexibility for a period of time prior to the liberalization of capital flows to allow the exchange market and hedging instruments to more fully develop.

\section{The staff agreed with the authorities that dealing with global imbalances} required a concerted effort on the part of all countries to take policy actions that were in each country's own interest. Staff acknowledged that on its own China's direct contribution to reducing the global imbalances would not be large, as suggested by the staff's analysis of the impact of a change in the renminbi's value, but stressed that it is the combined effect of adjustment in all countries that would make a major difference. This is why the Fund was calling for decisive policy actions by all major countries, including meaningful fiscal consolidation in the United States and structural reforms in Europe and Japan, to help deal with the problem. The staff also noted that greater renminbi flexibility should facilitate further flexibility in the exchange rates in some other currencies in Asia, thereby indirectly contributing to the orderly adjustment of global imbalances.

\section{Staff and the authorities agreed that greater flexibility, not simply a revaluation, remains a key objective in any change in the exchange rate regime. While there are} substantial pressures for appreciation in the near term and expected developments in the economy point to real exchange appreciation over the medium run, its extent is uncertain and the exchange rate may be subject to considerable short-term volatility. For example, continued increases in China's relative labor productivity and improved access to foreign markets would exert upward pressures, while the further opening of China's domestic market and the eventual liberalization of the capital account would generate depreciation pressures. How these factors play out over short time horizons is unclear. Increased flexibility would greatly facilitate the economy's ability to adjust to these pressures. In addition, increased flexibility would help to deepen spot and futures foreign exchange markets, which will not develop meaningfully until there is a perceived risk of two-way movements in the exchange rate. In terms of the monetary policy framework, the PBC would have greater policy independence, and accordingly, there would be a need for a new nominal anchor. Money and credit targeting for at least a while could continue to be used to set policy. Over time, China should consider moving toward inflation targeting for setting monetary policy, as adopted by many countries following moves to more flexible exchange rate regimes. In China, it will take some time before inflation targeting can be fully operationalized, given the lack of adequate and timely short-term indicators of demand and the need for institutional changes. 
27. The mission discussed with the authorities various options in choosing the initial step to introducing flexibility. Staff argued that this step should be significant enough to improve monetary policy independence and help curb speculative capital inflows by convincing market participants that no further changes were likely very soon. At the same time, there was a desire to avoid undue volatility in the exchange rate, particularly in the early stages of increasing flexibility when options for hedging are underdeveloped. To achieve these objectives, the authorities could widen the trading band around the U.S. dollar - at its present or at a revalued rate-or linked to a basket of currencies. The choice of approach involved trade-offs. A large widening of the band introduces greater flexibility, but it could entail the risk of potentially greater volatility. A smaller widening of the band combined with a revaluation and/or a shift to a basket link could result in less volatility, but it would only yield a limited increase in flexibility. Alternatively, a step revaluation alone, if large enough, could help to slow speculative inflows, but would not provide any flexibility.

\section{Fiscal Policy}

28. The likely outturn for the 2005 budget is broadly appropriate and in line with the objective of steadily bringing down the fiscal deficit over the medium term. This year's target for the nominal deficit was lowered from its level in the 2004 budget, despite including one-off payments for tax arrears. Based on the staff's growth forecast, the budget deficit in 2005 amounts to roughly 2 percent of GDP (official definition). Revenue is conservatively projected to increase by 11 percent, and expenditure is budgeted to rise by 14 percent. Part of the expenditure increase (and the rise in the budget deficit, relative to GDP, compared to last year's outturn) reflects a further and final clearance of outstanding VAT arrears (amounting to roughly 1 percentage point of GDP) and includes local government spending of the unspent revenues from 2004. The staff welcomed the shift, albeit relatively gradual, in the composition of spending in the 2005 budget away more from investment toward social spending, and encouraged the authorities to consider further reallocation in this direction to help constrain investment growth while increasing much needed spending on health and education.

\section{Given relatively conservative official estimates, the staff expected that the} revenue outturn for $\mathbf{2 0 0 5}$ could once again exceed the budget projection by a substantial amount (Tables 6 and 7). The staff urged the authorities to save any overperformance on revenues that accrues to the central government, and by so doing, provide in effect an "automatic stabilizer" to help restrain domestic demand. ${ }^{10}$ The authorities regarded the staff's estimate of revenue as overly optimistic, highlighting in particular the risk that restraints on China's exports by trading partners could reduce budget revenue and give rise to increased social spending to compensate adversely affected households. Nevertheless, they were confident that at a minimum the budget targets would be met.

\footnotetext{
${ }^{10}$ A Selected Issue paper explores the effectiveness of fiscal policy as a tool for macroeconomic management.
} 


\section{Over the medium term, continued fiscal consolidation will be needed to meet} likely large demands on public funds without jeopardizing debt sustainability. While explicit debt is relatively small (around 231/2 percent of GDP at end-2004) this substantially underestimates the likely extent of overall government liabilities. Contingent liabilities are large, arising from such sources as NPLs of state-owned banks built up largely as a result of lending to SOEs, "unrecorded" debt at the local level, and unfunded pension obligations. ${ }^{11}$ Their ultimate impact on the fiscal position will depend on how these liabilities are resolved, and comprehensive estimates of such fiscal costs are difficult to make at this juncture. The costs of SOE closures and social obligations transferred from SOEs to the government will add to these liabilities, as could rising health care costs as the population ages. In light of the government's likely large liabilities, the staff suggested that it would be appropriate to continue to reduce the fiscal deficit by at least $1 / 4$ to $1 / 2$ percent of GDP per year over the next few years, which was roughly consistent with the authorities' target of a constant nominal deficit. The staff also encouraged the authorities to make additional downward adjustments in their nominal deficit target when favorable conditions permit, as was the case in 2005 . In particular, with another possible overperformance of revenue relative to budget and all outstanding arrears on VAT refunds to be settled in 2005, there would be scope for a further significant reduction in the nominal deficit target in the 2006 budget. The authorities responded that they would continue to follow a prudent fiscal policy in the medium term, and the deficit would be consolidated depending on the evolution of the economy.

\section{Fiscal consolidation should be accompanied by strengthening the structure of} the public finances. ${ }^{12}$ In this regard, the staff urged further progress in a number of areas including shifting from a production- to a consumption-based VAT (now being successfully piloted in the North-East), adding services to the VAT tax net, and unifying the income tax rate for domestic and foreign-funded enterprises. Central and local fiscal relations are in need of reform, as income disparities across regions continue to widen, with some provinces facing difficulties funding some expenditure mandates. In this reform, consideration also needs to be given to the impact of population migration on local government finances. Structural imbalances in subnational finances need to be addressed, including by assessing the possibility of reforming tax assignments across levels of government, clarifying expenditure responsibilities, and reforming the transfer system to move toward a more rulebased equalization system. The staff also called for adequate transfers to local governments to fund existing pension and other social security liabilities.

\section{Strengthening fiscal management, including through better formulation and} execution of spending, would help to increase fiscal transparency and ensure that funds are spent for their intended purpose. The key to this is reforming the budget process, including by putting in place a revised budget classification system, better recording and

\footnotetext{
${ }^{11}$ NPLs in the banking system are reported to be around 191/2 percent of GDP as of end2004.
}

12 The Fund has provided extensive technical advice in this area (Annex I). 
reporting of spending, and further progress in implementing the treasury single account. There is also a need to strengthen revenue forecasting and cash management, to improve coordination with monetary policy. The authorities indicated that the revised budget classification system would be used to prepare the 2007 budget.

\section{Structural Reforms}

\section{A. Banking and Capital Market Reforms}

33. The authorities have placed banking reform at the center of the overall agenda to improve intermediation of China's large private savings. Progress has been made in strengthening supervision and in improving bank operations, especially in the three large state-owned commercial banks, which have been recapitalized. (Box 2). ${ }^{13}$ Financial restructuring of the Bank of China (BOC) and the China Construction Bank (CCB) has been completed, and the banks are on track to meet the first full set of quantitative performance benchmarks at end-2005, as specified in their restructuring plans. Preparations for IPOs have advanced and the sale of a 9 percent stake in the CCB to Bank of America corporation was announced in June 2005. In addition, the authorities have recently approved a restructuring plan for the Industrial and Commercial Bank of China (ICBC), the largest commercial bank in China, which involves significant public financial support and follows benchmarks similar to those set for the BOC and CCB. While under present circumstances financing bank recapitalization from central bank resources may be a pragmatic approach to speed up reform, the staff stressed that the quasi-fiscal liabilities acquired by the PBC in this process needed eventually to be transferred to the budget.

\section{The authorities and staff agreed that banks' balance sheets needed to be further} strengthened, and internal control systems, governance, and credit risk management in the state banks needed to be further improved. In addition, compliance with performance benchmarks had to be closely monitored and enforced. While the authorities pointed to the slowdown in lending by the three SCBs as an indication that their commercial orientation had improved, the staff was less certain, noting that establishing a credit culture and increasing the commercial orientation of these banks is a major undertaking, and it will inevitably take time before improvements in lending decisions become broad based. The staff acknowledged the progress made in reducing government involvement in management and business operations of banks. However, more needs to be done, particularly with regard to local governments, to remove this serious impediment to fully commercializing banks.

${ }^{13}$ A Selected Issues paper discusses progress in banking sector reform. 


\section{Box 2. Progress in Banking Reform}

Progress has been made in banking reforms, but considerable work remains to be done to improve the efficiency of banking intermediation. The two reform pilot banks, the newly incorporated Bank of China Ltd. (BOC) and China Construction Bank Corporation (CCB), have made steps to change their corporate governance structure and adjust operations. ${ }^{1}$ As a result of recapitalization, sales of nonperforming loans (NPLs), and other reform efforts, the banks' capital strength, asset quality and operating results improved. In 2004, operating profits of the BOC and CCB increased by approximately 15 percent, reported NPL ratios declined to 5 percent and 3.9 percent, respectively, and capital adequacy with full provisioning for NPLs exceeded the required minimum of 8 percent of risk-weighted assets. Both banks are on track to meeting the first full set of quantitative performance benchmarks at end-2005. Preparations for IPOs have advanced and the sale of a 9 percent stake in the CCB to Bank of America corporation was announced in June 2005. However, recent scandals - high-level corruption at the CCB and embezzlement at the $\mathrm{BOC}$ - call into question the effectiveness of existing internal control and corporate governance systems in the two banks. In April 2005, the government approved a reform plan for the Industrial and Commercial Bank of China (ICBC), the largest commercial bank in China. By mid-2005, the government is to provide financial support large enough to bring the ICBC's capital adequacy (with full provisioning for NPLs) to 8 percent and the bank is planning to raise additional capital in the market. The ICBC will follow the same reform process and performance benchmarks as the BOC and CCB.

\section{Aggregate capital adequacy improved and} reported NPLs were reduced, but it remains to be seen whether credit risk management improved sufficiently. In 2004, the aggregate capital of major state-owned commercial banks and joint stock commercial banks increased by 10 percent, reflecting a substantial increase of subordinated bond issues. The number of banks meeting regulatory capital requirements with full provisioning for NPLs, which now closely follow the Basel I standard, grew from 8 to 30, and these banks accounted for 48 percent of total bank assets. Bank NPLs were reduced in 2004, both in absolute value (by RMB395 billion) and as a ratio to total loans, by $4 \frac{1}{2}$ percentage points to $13 \frac{1}{4}$ percent and further to $12^{3 / 4}$ percent at end-

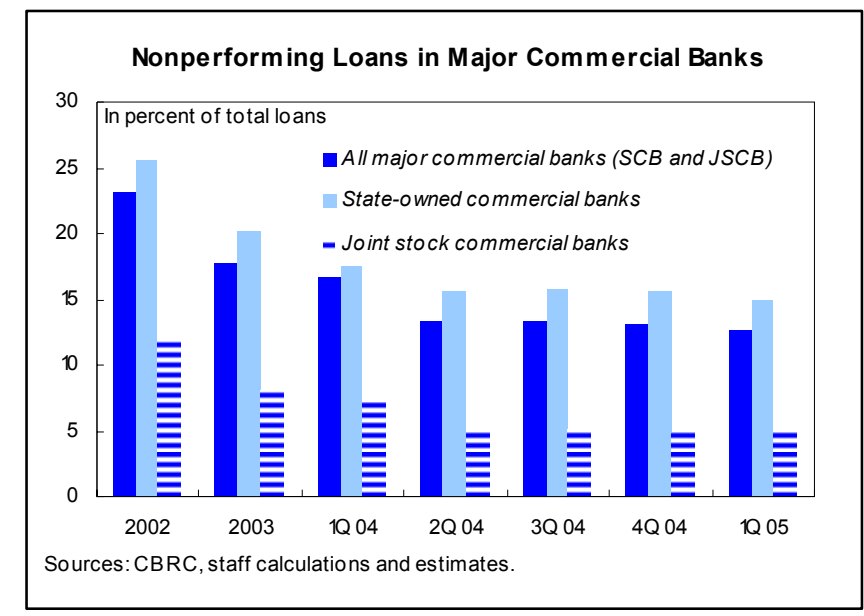

March 2005. However, the decline of NPLs was mainly due to transfers of bad assets to the AMCs, recapitalization, and write offs, and it remains unclear whether bank credit risk evaluation systems substantially improved. The AMCs have been slow to resolve bad assets, disposing of only 55 percent of their original NPLs as of endMarch 2005 (taking into account debt-equity swaps, about 70 percent of the original NPLs have been disposed).

Foreign ownership of banks has increased, which has the potential to improve governance and accelerate the transfer of technology and management practices. In 2004, the number of Chinese banks with foreign strategic investors doubled and reached 10. The entry of HSBC into the Bank of Communications, the fifth largest bank, was the most important transaction, and it may be viewed as a "pilot" for entry of strategic investors into the four stateowned banks. In banking supervision, regulations were issued or revised to strengthen credit authorization, risk management, and capital adequacy. The CBRC took steps to strengthen on-site examinations, monitoring of large exposures and connected lending.

${ }^{1}$ The four state-owned commercial banks account for approximately 60 percent of total banking assets, with the Industrial and Commercial Bank of China (ICBC) being the largest (holding about 20 percent of total assets) and the three other banks (BOC, CCB, and Agricultural Bank of China) comparable in size. 
35. The staff emphasized that particular attention should be given to activities of the Agricultural Bank (ABC), which has neither been restructured nor recapitalized. Relatively rapid expansion of the $\mathrm{ABC}$ 's lending may be creating new problems for itself and for other banks through the impact of its competition in certain segments of the credit market. Given this, the mission stressed the urgency of putting in place a restructuring plan, and the need to monitor very closely the bank's lending behavior. Although the authorities shared the staff's view that a restructuring plan for the $\mathrm{ABC}$ was imperative, they also pointed to the significant challenges that could arise given the scale of the bank's operations and the role it plays in the agricultural sector.

36. Along with the attention placed on the large state banks, reform efforts have also focused on the smaller banking institutions. In particular, the authorities aim to make the rural credit cooperatives (RCCs) more efficient vehicles of financial services to rural areas. A pilot program, launched in 2003 to improve the operations of the RCCs and to strengthen balance sheets through capital injections, was extended nationwide in 2004. Most aspects of RCC reform are expected to be completed by end-2007. The staff welcomed this initiative as potentially playing a significant role in helping to develop the rural sector. As in the case of the SCBs, establishing and supervising carefully the implementation of time-bound plans for improving the commercial orientation, risk management, internal controls, and governance arrangements for these institutions is essential for this reform to be successful. In addition, the availability of sufficient financing to properly recapitalize the RCCs is very important. In this regard, staff expressed some concerns, particularly regarding the possible sources of financing.

37. The staff welcomed the progress made in improving bank supervision. The $\mathrm{CBRC}$ has taken steps to strengthen on-site examinations and monitoring of large exposures and connected lending. The critical task for the CBRC will be to see that all banks are taking the necessary steps to ensure that they can comply with capital adequacy requirements with full provisioning by 2007, as required by existing guidelines. The PBC and the CBRC have been preparing an introduction of a deposit insurance scheme, which the staff cautioned should be designed and implemented with great care, particularly given the existing weaknesses in the banking sector. Staff also welcomed the PBC's plan to publish its first financial stability report this year.

\section{Progress has been made in reducing NPLs, but more efforts are needed to} accelerate the resolution of distressed assets and restrain the rate of new NPL creation. Although the recorded rate of new NPL creation has slowed, staff cautioned that this could be a misleading indicator of bank performance, as NPLs often surface only over time. Indeed, with banks heavily involved in lending to sectors facing future overcapacity, such as automobiles, steel, cement, and aluminum, credit risk in the banking sector is likely to remain high. Staff urged that steps be taken to accelerate the slow rate of disposal by AMCs of NPLs originally transferred to them from the banks. Staff also stressed that the adoption of a new bankruptcy law that provides sufficient protection for creditors will be important for addressing existing and future NPLs, and urged the authorities to ensure the law provides an adequate market mechanism to facilitate liquidation. The legal framework for creditor rights 
and foreclosure also needs to be improved, and bank and AMC incentives to resolve distressed debt would be enhanced by allowing full tax deductibility for specific loan loss provisions.

39. The staff emphasized the benefits of participating in an FSAP, which would help in formulating next steps in financial sector reform. The authorities indicated that a decision has been made to participate in a FSAP. The authorities still need to decide on the appropriate time to launch the process.

40. The staff discussed steps needed to accelerate the development of China's capital markets. The limited role of capital markets in China at present reflects the dominance of the state banks in intermediation, but these markets are also plagued with regulatory and governance problems. ${ }^{14}$ Increasing the role of bond and equity markets would improve intermediation, allow for more efficient pricing of credit risk, and strengthen management of financial risk.

\section{Despite China's strong economic growth, equity markets have performed}

poorly. Only relatively small portions of state-owned enterprises have been floated, and uncertainty regarding how the government will shed its holdings of nontraded shares overhangs the market, depressing share prices. Aborted attempts to sell these shares in the past have added to this uncertainty. To deal with the situation and begin the process of converting state-owned shares to tradable shares in listed companies, a new pilot program has been launched. This program provides for some compensation to existing shareholders by providing them additional shares in exchange for their consent to the floating of the remaining nontraded shares. The staff welcomed this approach to reducing the overhang and reviving the equity market, but it cautioned that the authorities' plan could give a small group of existing shareholders too much leverage in approving the public sale of remaining nontraded shares. This could lead to excess compensation and also slow the process of disposing of state-owned shares. The authorities responded that their approach of conducting these sales on a pilot basis would provide guidance for addressing the concerns raised by the staff when the scheme is ultimately expanded. In addition, the authorities have taken steps to clean up problems in a number of brokerage firms, and in the process, some limited measures have been adopted to compensate investors for the default of these firms. The staff cautioned against increased investor protection using public resources. The staff emphasized that the authorities' plans for a planned investor protection fund should carefully limit and define precisely what protection it should provide to investors to avoid creating substantial moral hazard.

\section{The staff discussed reforms to improve the functioning of the domestic bond}

market. Several government agencies currently play regulatory roles in the bond market, often with some overlap of responsibilities. As a result, the bond market is over-regulated,

\footnotetext{
${ }^{14}$ Impediments to the development of local corporate bond markets are explored in a Selected Issues paper.
} 
with state control inhibiting development. Streamlining the regulatory process is a priority. As a key first step, the current "merit-based" system requiring government selection of each individual corporate bond issue needs to be replaced with a system based on requiring firms to disclose operational and financial information, allowing the market to determine whether these firms can raise capital. At the same time, the current cap on corporate bond interest rates has to be removed to allow proper pricing. The authorities are considering changes along the lines the staff was proposing, but emphasized that, given the past problems with issuing bonds, a cautious approach would have to be followed. In addition, the staff suggested that steps be taken to unify the bond market, which was segmented with government bonds being traded on the interbank market and corporate bonds being listed on the stock exchange. Recently, the authorities took an important step in this direction by allowing some corporate bonds to trade on the interbank market.

\section{B. Reform of the State-Owned Enterprises}

\section{State-owned enterprises have become more market oriented, although further} reforms are needed. The state sector has shrunk over time (concentrating on key industries) with progress in corporate and management restructuring and increased foreign ownership. Many state enterprises are now profitable on a flow basis, as legacy debts and social responsibilities have been taken off their balance sheets. The improved cash position has resulted in higher enterprise profits, which have been largely reinvested rather than being returned to shareholders, especially to the government. ${ }^{15}$ This has been a major contributor to the rise in investment in recent years - with about half of total investment financed from retained earnings in 2004 (Box 3) — and has made demand management difficult by generating procyclical investment cycles.

\section{The staff encouraged the government to exercise stronger governance over} SOEs, in particular by strengthening the ownership role of the State Asset Supervision and Administration Commission (SASAC) and requiring profitable enterprises to pay dividends to the government. This will help improve public finances (for example, by using these resources to partially fund existing pension and social liabilities), focus enterprises on increasing their net worth, and help to stem the pace of investment. The staff also urged further progress in SOE restructuring, including the closing of unviable SOEs (enterprises that are not viable, but deemed to be socially important, should be supported directly through the budget), and improvement in accounting and auditing practice.

\section{Rural-Urban Income Disparity}

45. Rising urban-rural income disparity is a major concern of the authorities and they are taking a number of steps to address it. Plans are in place to extend reductions in local taxes on agricultural production — which were initiated in selected provinces in 2004

\footnotetext{
${ }^{15}$ High world commodity prices and monopoly positions in many sectors have also contributed to higher SOE profits in recent years.
} 
to more regions in 2005, with the aim of eliminating these taxes by 2006. Implementation of the Rural Land Contracting Law also is important in strengthening the agricultural sector. The law will improve the security of property rights and allow for the transfer and leasing of land, which will enhance the ability for farming to be done on a more efficient scale. In addition, the staff suggested that considerations should be given to allowing farmers to raise funds by using their land for loan collateral. This, together with the reform, restructuring, and recapitalization of the rural credit cooperatives, would expand the availability of rural financing, which will open up new opportunities to improve agricultural production and raise rural income over time. The authorities indicated that this issue would be addressed in the context of amending other key relevant legislation. The staff also suggested that further efforts to allow greater access to health and education for rural-urban migrants would also be helpful in encouraging the rural workforce to seek new employment opportunities, while the reorientation of government spending on basic services, such as health and education, at the local government level would help to improve worker skills. However, staff cautioned that unless appropriate accountability systems are put in place, any increase in spending might not fully deliver the desired benefits.

\section{Other Issues}

46. The authorities maintained that implementation of China's WTO commitments remains on track. The unweighted average tariff rate was reduced by another half percentage point to 10 percent in 2005, and key commitments with respect to banking services and trade and distribution rights have also moved forward. Except for a few products, tariff reductions required under WTO commitments beginning in 2005 have all taken effect, and quotas - except on agricultural products, which are in compliance with the WTO agreement-have been removed. The authorities see regional and bilateral free trade agreements as supplementary to multilateral agreements and are fully committed to further multilateral trade liberalization. They expressed, however, strong disappointment in the recent re-imposition of quotas by the United States and the EU on some textile products following the liberalization of textiles trade beginning this year. China has provided debt relief to low income countries under the enhanced HIPC Initiative.

47. The staff welcomes the commitment of the authorities to curb money laundering and combat the financing of terrorism (AML/CFT). Efforts are underway to put in place a framework consistent with the Financial Action Task Force (FATF) standards. China has recently become an observer to the FATF; however, there is work ahead in order to meet the requirements of full FATF membership, including the enactment of a comprehensive AML/CFT legislation. 


\section{Box 3. Who is Financing China's Investment?}

In the last 15 years, investment in China has been very strong, averaging 39 percent of GDP. Two large cycles dominate this period. The first peaked in 1993, when the investment-to-GDP ratio reached $43 \frac{1 / 4}{4}$ percent. The second is ongoing, and the investment-to-GDP ratio is projected to remain around 45 percent this year. Over the whole period, enterprises have invested on average about 30 percent of GDP, while households and government contributed 6 and 3 percent of GDP, respectively.

Most of this investment has been funded from domestic sources. Gross national saving over this period averaged 41 percent of GDP and is estimated to have reached 50 percent of GDP in 2004. Net foreign savings have been negative throughout this period (except in 1993), but this masks the small but increasing role of foreign direct investment in financing enterprise investment.

\section{Close to half of total fixed asset investment} is financed from internal funds of enterprises. Total internal funds used annually for investment purposes amounted to an average 15 percent of GDP, and reached $23 \frac{1}{2}$ percent of GDP in 2004 . One key reason for this large reliance on internal funds is that the majority of enterprises, which are fully or partially state-owned, do not distribute dividends to the state; instead, the state allows them to use these funds for investment. The shift toward more self-raised funds as source of financing in 2003-04 may also reflect tightening of monetary policy.

\begin{tabular}{|lrrrrrr|}
\hline \multicolumn{7}{|c|}{$\begin{array}{c}\text { China: Fixed Asset Investment--Sources of Growth } \\
\text { (In percent of total) }\end{array}$} \\
\hline \multicolumn{7}{|c}{} \\
& 1999 & 2000 & 2001 & 2002 & 2003 & 2004 \\
\hline State budget & 7.1 & 7.0 & 7.2 & 7.5 & 5.5 & 4.2 \\
Domestic loans & 22.9 & 23.9 & 22.2 & 22.8 & 23.5 & 20.4 \\
Bonds & 1.2 & 0.8 & 0.5 & 0.5 & 0.3 & 0.3 \\
Foreign capital & 7.6 & 6.2 & 5.5 & 5.2 & 4.8 & 4.3 \\
Self raised & 45.3 & 44.8 & 46.3 & 45.8 & 47.5 & 51.3 \\
Other & 15.9 & 17.3 & 18.3 & 18.3 & 18.4 & 19.5 \\
& & & & & & \\
\hline Source: CEIC. & & & & & & \\
\hline
\end{tabular}

Banks also have been an important source of investment financing (in the table, bank financing is categorized as domestic loans as well as "other" sources of funds, which include loans to individuals). In the last six years, domestic bank financing of enterprise investment averaged around 15 percent of GDP (measured by the net change in total loans to enterprises); however, this figure may overstate the extent of bank financing, as enterprise deposits have also grown strongly during this period.

The government and external funds have played a smaller, but still significant, role in financing investment in China. Government funding has been mostly in the form of transfers from the budget (mostly for infrastructure), averaging around 6-7 percent of GDP. Foreign funding of enterprise investment has been mostly limited to FDI, which has averaged around 4 percent of GDP in the last six years (based on balance of payments figures). These inflows have mainly come from other Asian economies (including Hong Kong SAR, Taiwan Province of China, Japan, and Korea), rather than from the United States and Europe. External debt and non-FDI private capital inflows have increased somewhat in the last three years, albeit from a very low base. 
48. The staff encouraged the authorities to continue to improve China's economic statistics. While China's data are adequate for surveillance purposes, weaknesses remain in key areas, including the national accounts, fiscal and labor statistics, and the balance of payments and international investment position. ${ }^{16}$ The staff suggested that efforts be focused in particular on publication of annual and quarterly real GDP on an expenditure basis; improving labor statistics; providing data that would facilitate on-going monitoring of the financial sector; measuring investment better, especially reforming the current practice of including land sales in fixed investment; and addressing the lack of reliable data on the change in business inventories.

\section{Staff Appraisal}

\section{China has continued to maintain a high rate of growth, while further} transforming the economy towards greater market orientation. Prospects for the future remain favorable, but risks are significant and need to be well managed through appropriate policy responses. Continued implementation of structural reforms in the financial sector, in SOEs, the labor market, and public finances are needed over the medium term. However, to establish a stable economic environment in which to implement further structural reform, macroeconomic policies have to deal with a number of significant near-term risks. In particular, policies need to ensure that the pace of investment and loan growth remains in check. Large capital inflows continue to add to the considerable liquidity already in the banking system, raising the risk that a resurgence in credit growth could tip off a sudden boom, fuel inflationary pressures, and lead to a further build-up in banks' NPLs. On the external front, growing protectionist sentiment in China's major markets could curb growth. In addition, a disorderly unwinding of global imbalances would have serious adverse effects on China's economy, as activity in the rest of the world would be adversely affected.

50. The authorities recognize the need to ensure that investment growth slows down sufficiently in the remainder of 2005. To this end, steps should be taken now to drain more of the existing liquidity out of the banking system through open market operations. If investment and lending growth appear to be rebounding, open market operations would need to be supplemented with increases in interest rates and reserve requirements. Such measures could be complemented, if needed, by further significant strengthening of prudential rules which would enhance overall financial stability and contribute to curbing near-term credit growth.

\footnotetext{
${ }^{16}$ China has participated in the GDDS, with its metadata posted on the official website (Dissemination Standards Bulletin Board) since April 2002.
} 


\section{The effectiveness of monetary instruments depends on the timeliness of policy}

actions. Accordingly, the $\mathrm{PBC}$ needs to be given more discretion to independently set interest rates. While consultation within the government may be beneficial in building support for an interest rate change, policy actions can be unduly delayed. Moreover, reliance on administrative means of control will have to diminish over time, as the increasing sophistication of the economy reduces their effectiveness and substantially raises the cost of the distortions that they create. As a step toward improving monetary policy effectiveness, consideration should be given to granting the $\mathrm{PBC}$ authority to set benchmark interest rates at least within a specified range as a transitional arrangement.

\section{Greater exchange rate flexibility continues to be in China's best interest, with an} early move desirable. It would help to strengthen macroeconomic control by increasing the independence of monetary policy and the ability of the economy to adjust to shocks. Given the desire to limit disruption to the domestic economy and with currency risk management instruments underdeveloped, a phased approach to full flexibility would be appropriate. While the authorities are best positioned to decide on the precise timing of an initial move, it would be best to make such a move from a position of economic strength, and an early move is warranted. This step would need to be significant enough to improve monetary policy independence and help curb speculative capital inflows by convincing market participants that no further immediate changes were likely. There are no impediments in the exchange and financial markets that would prevent taking such a step, and the continued strengthening of China's external position has added to the urgency of making this move.

\section{The costs associated with a continued delay in moving toward greater exchange} rate flexibility are growing. Over the near to medium term, delay in changing the current regime is likely to create continuing visible problems in the form of a further large build-up in reserves and growing difficulties in trying to sterilize the impact of these inflows on liquidity in the banking system. Less visible are the distortions in resource allocations that are being created and the likely build-up of short-term foreign currency liabilities, as Chinese firms would find it increasingly attractive over time to borrow funds offshore. The effectiveness of capital controls will also diminish in time. In such an environment, a negative shock to China's external position could put significant stress on the financial system. Although the costs of delay are not immediately apparent, they are present and growing.

54. In addition to serving China's own interest, greater flexibility would play a role in contributing to an orderly process for resolving global current account imbalances. A change in China's exchange rate regime on its own cannot be expected to have a major impact on global imbalances. Decisive policy actions are also required by all major countries, including a meaningful reduction in the United States' fiscal deficit and structural reforms in Europe and Japan. Greater renminbi flexibility would be expected to facilitate increased flexibility in the exchange rates of some of the other Asian economies, which would also contribute to an orderly global adjustment. 
55. The likely outturn of the $\mathbf{2 0 0 5}$ budget is broadly appropriate. The shift in expenditure from investment to social areas is welcome, but further reallocation in this direction would help constrain investment growth while increasing much needed spending on health and education. In the current environment, the revenue outturn could once again significantly exceed the budget target. The authorities should save any overperformance on revenues that accrues to the central government, thereby helping to restrain domestic demand.

56. Over the medium term, further fiscal consolidation will be needed to meet likely large demands on public funds, including those associated with contingent liabilities, without jeopardizing debt sustainability. The staff continues to recommend that reducing the deficit by $1 / 4-1 / 2$ percent of GDP per year should be the medium-term goal. Moreover, the authorities should make additional downward adjustments in their nominal deficit target, as undertaken this year, when similar favorable conditions permit. With another overperformance of revenue relative to budget likely and all outstanding arrears on VAT refunds to be settled in 2005, there would be scope for a further significant cut in the nominal deficit target in the 2006 budget.

57. Fiscal consolidation should be accompanied by strengthening the structure of the public finances. In this regard, the staff urges further progress in shifting from a production- to a consumption-based VAT, extending the VAT to cover services, and unifying the income tax rate for domestic and foreign-funded enterprises. Structural imbalances in subnational finances should be addressed, including by assessing the possibility of reforming tax assignments across levels of government, clarifying expenditure responsibilities, and reforming the transfer system to move toward a more rule-based equalization system. The central government should also make adequate resources available to local governments to fund existing pension and other social liabilities.

58. Strengthening fiscal management would help to ensure that funds are spent for their intended purpose. In particular, better formulation and execution of spending is required. The key to this is reforming the budget process, including by putting in place a revised budget classification system, better recording and reporting of spending, and further progress in implementing the treasury single account.

59. Improving intermediation of China's large private savings is critical to medium-term prospects for rapid and stable growth. Bank restructuring is a key element in this reform. The authorities are making progress, especially in three of the four large commercial banks, but much remains to be done. Particular attention needs to be given to the activities of the $\mathrm{ABC}$, where expansion of lending operations may be creating new problems for the $\mathrm{ABC}$ itself and other banks. All of the state banks require strengthening their balance sheets, and additional improvements in their commercial orientation, risk management, internal controls, and governance. The banks have to learn to price risk appropriately, and accordingly, they should make full use of the latitude given to them by last year's liberalization of lending rates, which was an important step taken by the PBC to help develop the banking sector. The involvement of all levels of government in bank management and 
business operations needs to be eliminated. Diversifying bank ownership, for example by allowing qualified foreign financial institutions to take strategic stakes, also could bring much needed technical expertise and better governance. Continued close monitoring of progress in meeting the benchmarks set out in the restructuring plans for the three large stateowned commercial banks that have been recapitalized remains particularly important. So far, the central bank has provided the bulk of the resources needed for the restructuring of the banking system. While this reflects current circumstances and a pragmatic approach taken in order to speed up the reform process, these quasi-fiscal liabilities need eventually to be transferred to the budget.

\section{The CBRC continues to make progress in improving bank supervision. Further} strengthening of supervision will aid the bank reform process. It is essential to ensure that all banks can achieve capital adequacy requirements with full provisioning by 2007, as required by existing guidelines. The adoption of a new bankruptcy law that provides sufficient protection to creditors will be important for resolving existing and future NPLs in an orderly manner, and it is critical that the law allows for an adequate market mechanism to facilitate liquidation. Incentives to resolve distressed debt would be enhanced by allowing full tax deductibility for specific loan loss provisions.

\section{Increasing the role of bond and equity markets would also improve financial} intermediation. To reduce the overhang of existing nontraded shares in the equity markets, the authorities have introduced a pilot program to allow them to be tradable. They have also taken some limited measures to compensate investors for the default of brokerage firms. However, care needs to be taken to ensure that public resources are not used to protect investors, just as the authorities need to be careful in limiting and defining precisely what protection it provides to investors to avoid creating moral hazard. In the bond market, a key first step would be to eliminate the current system of government approval for firms to issue corporate bonds, and replace it with a more market-oriented system based on disclosure of operational and financial information for issuing firms. The cap on corporate bond interest rates also needs to be removed to allow proper pricing of such bonds.

62. China's decision to participate in an FSAP is welcome. This could help in drawing up a blueprint for further reform and development of the entire financial sector. It would be useful to quickly reach agreement on the timing of the FSAP.

\section{Staff welcomes progress in making SOEs more market oriented, although} additional reforms are still needed. Some enterprises have been able to substantially expand their operations in recent years by reinvesting the large profits they have enjoyed. To ensure that these funds are well invested, a priority is for the government to exercise stronger governance over these SOEs, including by strengthening SASAC's ownership role and requiring profitable SOEs to pay dividends to the government. This could help improve public finances, focus enterprises more on increasing their net worth, and could significantly help stem the pace of investment growth. 
64. Continued trade reform is important for China to expand its market access in industrial countries and sustain its integration with the global economy. The IMF staff welcomes the authorities' intention to implement remaining WTO commitments as scheduled and China's ongoing support for the completion of the Doha Development Round.

65. The IMF staff welcomes improvements in the quality of economic statistics, although incomplete data in several areas still affects the monitoring of macroeconomic developments. A continuing major priority for further improvement is the compilation and timely publication of annual and quarterly real GDP data on an expenditure basis. Balance of payments statistics are another area that needs attention, and the authorities are utilizing Fund technical assistance to improve these data and ensure that the reporting of data on the international investment position is done as soon as feasible. Other efforts should be focused on improving labor statistics and providing data that would facilitate on-going monitoring of the financial sector.

66. It is proposed that the next Article IV consultation with China take place on the standard 12-month cycle. 
Table 1. China: Summary Indicators

Nominal GDP (2004): US\$1,654 billion

Population (2004): 1.299 billion

GDP per capita (2004): US\$1,269

Quota: SDR 6,370 million

\begin{tabular}{|c|c|c|c|c|c|c|}
\hline & 2000 & 2001 & 2002 & 2003 & $\frac{2004}{\text { Est. }}$ & $\frac{2005}{\text { Proj. }}$ \\
\hline & \multicolumn{6}{|c|}{ (Change in percent) } \\
\hline Real GDP (production) & 8.0 & 7.5 & 8.3 & 9.5 & 9.5 & 9.0 \\
\hline Real GDP (expenditure) 1/ & 7.4 & 9.1 & 9.7 & 11.9 & 11.1 & $\ldots$ \\
\hline Real domestic demand & 6.8 & 8.0 & 7.9 & 9.7 & 8.7 & 8.0 \\
\hline Consumer prices (period average) & 0.4 & 0.7 & -0.8 & 1.2 & 3.9 & 3.0 \\
\hline \multirow[t]{2}{*}{ Registered unemployment rate in urban areas (in percent) } & 3.1 & 3.6 & 4.0 & 4.3 & 4.2 & $\ldots$ \\
\hline & \multicolumn{6}{|c|}{ (In percent of GDP) } \\
\hline Total capital formation & 36.3 & 38.5 & 40.2 & 43.9 & 45.2 & 46.3 \\
\hline Of which: Fixed capital formation & 36.5 & 37.8 & 39.9 & 43.7 & 44.8 & 46.1 \\
\hline Gross national saving & 38.2 & 40.0 & 43.0 & 47.2 & 49.3 & 52.4 \\
\hline External current account & 1.9 & 1.5 & 2.8 & 3.2 & 4.2 & 6.0 \\
\hline Overall budget balance, IMF basis 2 / & -3.6 & -3.1 & -3.3 & -2.8 & -1.7 & -1.7 \\
\hline Revenue & 15.3 & 17.0 & 18.2 & 18.7 & 19.4 & 19.6 \\
\hline Expenditure (including net lending) & 18.9 & 20.1 & 21.5 & 21.5 & 21.1 & 21.4 \\
\hline Overall budget balance, authorities definition, in bn RMB & -250 & -246 & -315 & -293 & -201 & -240 \\
\hline Overall budget balance, authorities definition & -2.8 & -2.5 & -3.0 & -2.5 & -1.5 & -1.5 \\
\hline \multirow[t]{2}{*}{ Government gross debt ( in percent of GDP) } & 22.2 & 23.6 & 25.1 & 25.6 & 23.6 & 22.3 \\
\hline & \multicolumn{6}{|c|}{ (Change in percent; end of period) } \\
\hline Banking system's net domestic assets 3/ & 10.8 & 16.5 & 15.3 & 19.7 & 7.7 & $\ldots$ \\
\hline Of which: Domestic credit 3/4/ & 21.2 & 6.5 & 21.6 & 19.6 & 11.3 & $\ldots$ \\
\hline Broad money $3 /$ & 17.0 & 14.4 & 16.8 & 19.6 & 14.6 & $\ldots$ \\
\hline Reserve money & 8.5 & 9.2 & 13.3 & 17.1 & 11.4 & $\ldots$ \\
\hline \multirow[t]{2}{*}{ Interest rate (one-year time deposits, year-end) } & 2.3 & 2.3 & 2.0 & 2.0 & 2.3 & $\ldots$ \\
\hline & \multicolumn{6}{|c|}{ (In billions of U.S. dollars) } \\
\hline Current account balance & 21 & 17 & 35 & 46 & 69 & 114 \\
\hline Of which: Exports & 249 & 266 & 326 & 438 & 593 & 750 \\
\hline Imports & 215 & 232 & 281 & 394 & 534 & 654 \\
\hline Capital and financial account balance 5/ & 2 & 35 & 32 & 53 & 111 & 96 \\
\hline Of which: Direct investment inflows (net) & 37 & 37 & 47 & 47 & 53 & 55 \\
\hline Errors and omissions & -12 & -5 & 8 & 18 & 27 & $\ldots$ \\
\hline Change in net international reserves (increase -) & -11 & -47 & -76 & -117 & -206 & -210 \\
\hline Gross international reserves $6 /$ & 172 & 219 & 295 & 412 & 619 & 829 \\
\hline In months of imports of goods and nonfactor services & 7.6 & 8.0 & 7.9 & 8.2 & 10.1 & 11.0 \\
\hline As a percent of short-term external debt $7 /$ & 1,316 & 432 & 530 & 535 & 593 & 607 \\
\hline External debt $7 /$ & 146 & 170 & 171 & 194 & 229 & 303 \\
\hline Of which: Short-term debt 7/ & 13 & 44 & 48 & 73 & $\ldots$ & $\ldots$ \\
\hline Debt-service ratio (in percent of exports) 7/ & 7.3 & 7.1 & 14.8 & 12.3 & 12.5 & 14.6 \\
\hline have since been included. & 8.28 & 8.28 & 8.28 & 8.28 & 8.28 & $\ldots$ \\
\hline Nominal effective exchange rate 8 / & 73 & 77 & 76 & 71 & 67 & $\ldots$ \\
\hline Real effective exchange rate 8 / & 109 & 115 & 112 & 103 & 101 & $\cdots$ \\
\hline \multicolumn{7}{|l|}{ Memorandum items: } \\
\hline Nominal GDP (in billions of RMB) & 8,947 & 9,731 & 10,517 & 11,739 & 13,688 & 15,665 \\
\hline Exports growth (value terms, in percent) & 27.9 & 6.8 & 22.4 & 34.6 & 35.4 & 26.4 \\
\hline Imports growth (value terms, in percent) & 35.2 & 8.1 & 21.3 & 39.8 & 35.8 & 22.4 \\
\hline Net imports of oil (in billions of USD) & 14.3 & 12.0 & 13.2 & 20.9 & 38.6 & 62.7 \\
\hline (In percent of GDP) & 1.3 & 1.0 & 1.0 & 1.5 & 2.3 & 3.3 \\
\hline Real GDP growth of trading partners (in percent) & 5.4 & 0.8 & 1.7 & 2.3 & 4.6 & 2.9 \\
\hline
\end{tabular}

Sources: Data provided by the Chinese authorities; and staff estimates and projections.

1/ IMF staff estimate.

2/ Central and local governments, including all official external borrowing.

3/ Banking survey.

4/ The growth rates are corrected for the transfer of NPLs from banks to the AMCs.

5/ For 2005, includes errors and omissions.

6/ Includes gold, SDR holdings, and reserve position in the Fund.

7/ Official data sources. The coverage and classification of official external debt data were modified in 2001. Categories of debt

previously not covered are now included.

8 / Annual averages $(1990=100)$, using revised weights. 
Table 2. China: Quarterly Balance of Payments (In billions of U.S. dollars)

\begin{tabular}{|c|c|c|c|c|c|c|c|c|c|}
\hline & \multirow{2}{*}{2000} & \multirow[t]{2}{*}{2001} & \multirow[t]{2}{*}{2002} & \multirow[t]{2}{*}{2003} & \multicolumn{5}{|c|}{2004} \\
\hline & & & & & Q1 & Q2 & Q3 & Q4 & Year \\
\hline Current Account Balance & 20.5 & 17.4 & 35.4 & 45.9 & 3.3 & 4.1 & 16.1 & 45.1 & 68.7 \\
\hline Trade balance & 34.5 & 34.0 & 44.2 & 44.7 & -2.6 & 8.4 & 17.9 & 35.2 & 59.0 \\
\hline Exports & 249.1 & 266.1 & 325.7 & 438.3 & 115.4 & 142.4 & 158.2 & 177.3 & 593.4 \\
\hline Imports (BOP basis) & 214.7 & 232.1 & 281.5 & 393.6 & 118.0 & 134.0 & 140.3 & 142.1 & 534.4 \\
\hline Services & -5.6 & -5.9 & -6.8 & -8.6 & -1.4 & -4.5 & -4.0 & 0.2 & -9.7 \\
\hline Income & -14.7 & -19.2 & -14.9 & -7.8 & 2.2 & -4.6 & -3.2 & 2.1 & -3.5 \\
\hline Current transfers & 6.3 & 8.5 & 13.0 & 17.6 & 5.1 & 4.8 & 5.5 & 7.6 & 22.9 \\
\hline Capital and Financial Account Balance & 1.9 & 34.8 & 32.3 & 52.7 & 36.7 & 30.1 & 6.2 & 37.7 & 110.7 \\
\hline Capital Account & 0.0 & -0.1 & 0.0 & 0.0 & 0.0 & 0.0 & 0.0 & 0.0 & -0.1 \\
\hline Financial Account & 2.0 & 34.8 & 32.3 & 52.8 & 36.8 & 30.1 & 6.1 & 37.8 & 111 \\
\hline Net foreign direct investment & 37.5 & 37.4 & 46.8 & 47.2 & 12.5 & 18.0 & 12.5 & 10.1 & 53.1 \\
\hline inward investment (net) & 38.4 & 44.2 & 49.3 & 47.1 & 13.0 & 18.5 & 13.0 & 10.4 & 54.9 \\
\hline abroad & -0.9 & -6.9 & -2.5 & 0.2 & -0.5 & -0.6 & -0.5 & -0.3 & -1.8 \\
\hline Portfolio investment & -4.0 & -19.4 & -10.3 & 11.4 & 16.8 & 11.0 & -7.6 & -0.5 & 19.7 \\
\hline assets & -11.3 & -20.7 & -12.1 & 3.0 & 15.2 & 5.7 & -9.3 & -5.2 & 6.5 \\
\hline liabilities & 7.3 & 1.2 & 1.8 & 8.4 & 1.5 & 5.2 & 1.7 & 4.7 & 13.2 \\
\hline Other investment & -31.5 & 16.9 & -4.1 & -5.9 & 7.5 & 1.2 & 1.2 & 28.1 & 37.9 \\
\hline assets $1 /$ & -43.9 & 20.8 & -3.1 & -17.9 & 0.0 & -28.5 & 6.2 & 24.4 & 2.0 \\
\hline liabilities & 12.3 & -3.9 & -1.0 & 12.0 & 6.4 & 28.7 & -3.6 & 0.8 & 32.3 \\
\hline Errors and Omissions 2/ & -11.9 & -4.9 & 7.8 & 18.4 & -3.8 & -3.5 & 21.6 & 12.6 & 27.0 \\
\hline Overall Balance & 10.5 & 47.3 & 75.5 & 117.0 & 36.3 & 30.7 & 43.9 & 95.5 & 206.4 \\
\hline Reserve assets & -10.5 & -47.3 & -75.5 & -117.0 & -36.3 & -30.7 & -43.9 & -95.5 & -206.4 \\
\hline \multicolumn{10}{|l|}{ Memo items: } \\
\hline Current account as percent of GDP & 1.9 & 1.5 & 2.8 & 3.2 & 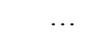 & & .. & & 4.2 \\
\hline Export growth (value terms) & 27.9 & 6.8 & 22.4 & 34.6 & 33.8 & 36.8 & 35.0 & 35.7 & 35.4 \\
\hline Import growth (value terms) & 35.4 & 8.1 & 21.3 & 39.8 & 41.8 & 43.1 & 30.3 & 30.3 & 35.8 \\
\hline FDI (inward) as a percent of GDP & 3.6 & 3.8 & 3.9 & 3.3 & $\ldots$ & $\ldots$ & $\ldots$ & $\ldots$ & 3.3 \\
\hline External debt & 145.7 & 170.1 & 171.4 & 193.6 & $\ldots$ & $\ldots$ & $\ldots$ & $\ldots$ & 228.6 \\
\hline as a percent of GDP & 13.5 & 14.5 & 13.5 & 13.7 & $\ldots$ & $\ldots$ & $\ldots$ & $\ldots$ & 13.8 \\
\hline Short term external debt (original maturity) & 13.1 & 43.9 & 47.9 & 73.0 & $\ldots$ & 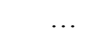 & $\ldots$ & $\ldots$ & \\
\hline Gross reserves & 172.1 & 218.7 & 295.2 & 412.2 & 448.5 & 479.2 & 523.1 & 618.6 & 618.6 \\
\hline as a percent of ST debt by remaining maturity & 1316 & 432 & 530.0 & 535.0 & $\ldots$ & $\ldots$ & $\ldots$ & $\ldots$ & 593.1 \\
\hline Nominal GDP & 1,081 & 1,176 & 1,271 & 1,418 & $\ldots$ & $\ldots$ & $\ldots$ & $\ldots$ & 1,654 \\
\hline
\end{tabular}

Sources: Chinese authorities and IMF staff calculations

1/ 2003 figure includes the counterpart transaction to the US\$ 45 billion of foreign exchange reserves used for bank recapitalization. 2 / Includes counterpart transaction to valuation changes. 
Table 3. China: External Debt

(In billions of U.S. dollars)

\begin{tabular}{|c|c|c|c|c|c|}
\hline & 2000 & 2001 & 2002 & 2003 & 2004 \\
\hline By Debtor & 145.7 & 170.1 & 171.4 & 193.7 & 228.6 \\
\hline Government and government agencies & 49.0 & 49.8 & 50.5 & 34.1 & 33.6 \\
\hline Domestic entities & 49.1 & 45.7 & 46.3 & 64.3 & 72.3 \\
\hline Chinese enterprises & 13.5 & 11.2 & 10.0 & 7.6 & 6.0 \\
\hline Chinese banks & 29.8 & 30.1 & 31.9 & 56.3 & 66.0 \\
\hline Chinese non-bank financial institutions & 5.7 & 4.4 & 4.4 & 0.3 & 0.3 \\
\hline Foreign funded entities & 46.5 & 52.2 & 48.2 & 58.7 & 76.2 \\
\hline Foreign-funded enterprises & $\ldots$ & 35.2 & 33.2 & 37.8 & 44.6 \\
\hline Foreign funded banks & $\ldots$ & $\ldots$ & 14.5 & 20.9 & 31.6 \\
\hline Trade credit & $\ldots$ & 21.6 & 26.3 & 36.6 & 46.5 \\
\hline Other & 1.2 & 0.8 & 0.0 & 0.0 & 0 \\
\hline By Creditor & 145.7 & 170.1 & 171.4 & 193.6 & 228.6 \\
\hline Official creditors & 51.0 & 51.27 & 52.1 & 51.9 & 57.3 \\
\hline Multilateral & 26.3 & 27.57 & 27.7 & 26.5 & 25.1 \\
\hline Bilateral & 24.6 & 23.70 & 24.4 & 25.4 & 32.2 \\
\hline Commercial banks & 46.2 & 46.54 & 44.1 & 53.7 & $\ldots$ \\
\hline foreign banks and financial institutions & 32.9 & 33.49 & 31.7 & 42.4 & $\ldots$ \\
\hline suppliers (buyer's credit) & 13.2 & 13.05 & 12.4 & 11.3 & $\ldots$ \\
\hline Bonds & 12.3 & 12.7 & 10.8 & 11.2 & $\ldots$ \\
\hline Other & 36.3 & 59.64 & 64.3 & 76.9 & $\ldots$ \\
\hline Loans from non-bank financial sources & 22.9 & 23.65 & 24.2 & 28.9 & $\ldots$ \\
\hline International financial leasing & 11.9 & 10.10 & 9.2 & 7.7 & $\ldots$ \\
\hline Trade credits & & 21.61 & 26.3 & 36.6 & $\ldots$ \\
\hline Deferred payments & 1.6 & 2.75 & 3.2 & 1.2 & $\ldots$ \\
\hline Deposits from overseas & 0.0 & 1.54 & 1.4 & 2.5 & .. \\
\hline \multicolumn{6}{|l|}{ By Maturity } \\
\hline Medium and long-term debt & 132.6 & 126.2 & 123.5 & 120.7 & 124.3 \\
\hline Short-term debt (remaining maturity basis) & & 51 & 56 & 77 & 104.3 \\
\hline Short-term debt (original maturity basis) & 13 & 44 & 48 & 73 & $\ldots$ \\
\hline \multicolumn{6}{|l|}{ Memorandum item: } \\
\hline Gross international reserves & 172.1 & 218.7 & 295.2 & 412.2 & 618.6 \\
\hline
\end{tabular}

Sources: Chinese Authorities and staff calculations.

1/ The breakdown of debt by debtor and coverage of entities were changed in 2001. In addition, loans from foreign governments to policy banks are moved from debt of government category to debt of Chinese-funded financial institutions from end-2003 onward. The adjustment was $\$ 15.2$ billion at end-2003.

In 2001, trade credits and loans borrowed by foreign funded financial institutions are included. Their stock at end-2001 was 38.7 billion. 
Table 4. China: Indicators of External Vulnerability

\begin{tabular}{|c|c|c|c|c|c|c|}
\hline & 2000 & 2001 & 2002 & 2003 & 2004 & $\begin{array}{l}2005 \\
\text { Proj. }\end{array}$ \\
\hline \multicolumn{7}{|l|}{ Monetary and Financial indicators } \\
\hline Public sector domestic debt (official data; in percent of GDP) & 17.7 & 19.4 & 21.2 & 21.9 & 20.5 & 19.6 \\
\hline Broad money (M2: annual percentage change) & 14.0 & 14.4 & 16.8 & 19.6 & 14.6 & $\ldots$ \\
\hline Foreign currency deposits to broad money (percent) & 7.7 & 7.1 & 6.7 & 5.6 & 5.0 & $\ldots$ \\
\hline Credit to nonstate sectors (annual percentage change) & 18.1 & 8.5 & 15.3 & 21.2 & $\ldots$ & $\ldots$ \\
\hline Foreign currency loans to credit to the economy (in percent) & 4.2 & 5.2 & 5.0 & 5.4 & 5.1 & $\ldots$ \\
\hline Stock Exchange Index (end of period, Dec. 19, $1990=100$ ) $1 /$ & 2,192 & 1,713 & 1,419 & 1,569 & 1,330 & $\ldots$ \\
\hline Stock Exchange capitalization (percent of GDP) & 53.8 & 44.4 & 36.4 & 36.3 & 27.4 & $\ldots$ \\
\hline Number of listed companies & 572 & 646 & 715 & 780 & 837 & $\ldots$ \\
\hline \multicolumn{7}{|l|}{ Balance of payments indicators } \\
\hline Exports (annual percentage change, U.S. dollars) & 27.9 & 6.8 & 22.4 & 34.6 & 35.4 & 26.4 \\
\hline Imports (annual percentage change, U.S. dollars) & 35.4 & 8.1 & 21.3 & 39.8 & 35.8 & 22.4 \\
\hline Current account balance (percent of GDP) & 1.9 & 1.5 & 2.8 & 3.2 & 4.2 & 6.0 \\
\hline Capital and financial account balance (percent of GDP) & 0.2 & 3.0 & 2.5 & 3.7 & 6.7 & 1.4 \\
\hline Of which: Gross foreign direct investment inflows & 3.6 & 3.8 & 3.9 & 3.3 & 3.3 & 3.0 \\
\hline \multicolumn{7}{|l|}{ Reserve indicators } \\
\hline Gross reserves (billions of U.S. dollars) & 172 & 219 & 295 & 412 & 619 & $\ldots$ \\
\hline Gross reserves to imports of GNFS (months) & 7.6 & 8.0 & 7.9 & 8.2 & 10.1 & $\ldots$ \\
\hline Gross reserves to broad money (M2) (percent) & 10.4 & 11.4 & 13.2 & 15.4 & 20.2 & $\ldots$ \\
\hline Gross reserves to short-term external debt by remaining maturity (percent) 3/ & 1316 & 432 & 530 & 535 & 593 & ... \\
\hline \multicolumn{7}{|l|}{ External debt and balance sheet indicators 4/ } \\
\hline Total external debt (percent of GDP) & 11.5 & 12.0 & 10.4 & 10.2 & 10.8 & 12.8 \\
\hline Total external debt (billions of U.S. dollars) & 145.7 & 170.1 & 171.4 & 193.7 & 228.6 & 303.4 \\
\hline Of which: Public and publicly guaranteed debt $5 /$ & 49.0 & 49.8 & 50.5 & 34.1 & 33.6 & $\ldots$ \\
\hline Banking sector debt & 29.8 & 30.1 & 31.9 & 56.3 & 66.0 & $\ldots$ \\
\hline Short-term external debt by original maturity (billions of U.S. dollars) & 13.1 & 43.9 & 47.9 & 73.0 & $\ldots$ & $\ldots$ \\
\hline Short-term external debt by remaining maturity (billions of U.S. dollars) & $\ldots$ & 50.6 & 55.7 & 77.0 & 104.3 & $\ldots$ \\
\hline Net foreign assets of banking sector (billions of U.S. dollars) & 64.5 & 88.6 & 109.8 & 88.6 & 114.0 & $\ldots$ \\
\hline Total debt to exports of GNFS (percent) & 52.1 & 56.8 & 46.9 & 39.9 & 34.9 & 40.5 \\
\hline Total debt service to exports of GNFS (percent) & $\ldots$ & $\ldots$ & 14.8 & 12.3 & 12.5 & 14.6 \\
\hline Of which: Interest payments to exports of GNFS (percent) & $\ldots$ & $\ldots$ & 0.9 & 0.8 & 0.8 & 0.7 \\
\hline Bond spread (benchmark bond, end of period, basis points) & 162 & 107 & 97 & 86 & 64 & $\ldots$ \\
\hline \multicolumn{7}{|l|}{ Foreign-Currency Sovereign Bond Ratings } \\
\hline Moody's & A3 & A3 & A3 & A2 & A2 & $\ldots$ \\
\hline Standard and Poor's & BBB & BBB & BBB & BBB & $\mathrm{BBB}+$ & $\ldots$ \\
\hline \multicolumn{7}{|l|}{ Memorandum items: } \\
\hline Nominal GDP (US\$ billions) & 1,081 & 1,176 & 1,271 & 1,418 & 1,654 & 1,893 \\
\hline Exports of GNFS (US\$ billions) & 280 & 299 & 365 & 485 & 656 & 750 \\
\hline Real effective exchange rate (end of period, annual percentage change) & 6.7 & 2.8 & -7.1 & -6.6 & -3.8 & .. \\
\hline
\end{tabular}

Sources: Chinese authorities and Fund staff estimates and projections.

1/ Shanghai Stock Exchange, A share.

2/ The sum of the current account, FDI inflows, and identified non-FDI flows from BIS data less reserve accumulation.

3/ Based on BIS debt data until 2000, and on official data from 2001 on.

4/ Based on official debt data unless otherwise indicated.

5/ Debt of banking sector not included. 
Table 5. China: Monetary Developments

\begin{tabular}{|c|c|c|c|c|c|c|c|c|c|}
\hline & \multirow[t]{2}{*}{2000} & \multirow[t]{2}{*}{2001} & \multirow[t]{2}{*}{2002} & \multirow[t]{2}{*}{2003} & \multicolumn{4}{|c|}{2004} & \multirow{2}{*}{$\frac{2005}{\text { March }}$} \\
\hline & & & & & March & June & Sep. & Dec. & \\
\hline & \multicolumn{9}{|c|}{ (In billions of yuan) } \\
\hline Net foreign assets & 2,012 & 2,642 & 3,175 & 3,773 & 4,139 & 4,492 & 4,836 & 5,535 & 5,961 \\
\hline Net domestic assets & 11,449 & 13,188 & 15,326 & 18,349 & 19,015 & 19,337 & 19,525 & 19,770 & 20,483 \\
\hline Domestic credit $1 /$ & 11,725 & 12,556 & 17,262 & 20,628 & 21,239 & 21,392 & 21,748 & 22,527 & 23,110 \\
\hline Net credit to government & 588 & 1,102 & 1,333 & 1,318 & 1,231 & 1,124 & 1,076 & 1,550 & 1,219 \\
\hline Credit to non-government & 11,137 & 11,454 & 15,929 & 19,311 & 20,008 & 20,268 & 20,672 & 20,878 & 21,891 \\
\hline Other items, net 1 / & -276 & 632 & $-1,936$ & $-2,279$ & $-2,224$ & $-2,055$ & $-2,223$ & $-2,672$ & $-2,628$ \\
\hline Broad money & 13,461 & 15,830 & 18,501 & 22,122 & 23,165 & 23,843 & 24,376 & 25,411 & 26,459 \\
\hline Reserve money & 3,649 & 3,985 & 4,514 & 5,284 & 5,046 & 5,131 & 5,315 & 5,886 & 5,759 \\
\hline \multicolumn{10}{|l|}{ Of which: } \\
\hline Required reserves & 720 & 850 & 1,006 & 1,410 & 1,487 & 1,645 & 1,674 & 1,738 & 1,825 \\
\hline Excess reserves & 879 & 857 & 907 & 845 & 634 & 570 & 535 & 987 & 764 \\
\hline Net foreign assets of PBC & 1,519 & 1,935 & 2,282 & 3,066 & 3,346 & 3,589 & 3,893 & 4,640 & 5,081 \\
\hline Net domestic assets of $\mathrm{PBC}$ & 2,130 & 2,050 & 2,232 & 2,218 & 1,700 & 1,541 & 1,422 & 1,246 & 677 \\
\hline & \multicolumn{9}{|c|}{ (Twelve-month percentage change) } \\
\hline Net foreign assets $2 /$ & 2.6 & 4.7 & 3.4 & 3.2 & 3.9 & 4.8 & 5.4 & 8.0 & 7.9 \\
\hline Net domestic assets & 11.3 & 15.2 & 16.2 & 19.7 & 18.3 & 13.8 & 10.5 & 7.7 & 7.7 \\
\hline Domestic credit 3/ 4/ & 9.7 & 6.4 & 30.7 & 19.6 & 18.0 & 14.2 & 11.6 & 11.3 & 10.7 \\
\hline Of which: Loans & 13.4 & 11.6 & 15.4 & 21.1 & 20.1 & 16.3 & 13.6 & 14.5 & 13.0 \\
\hline Other items, net $2 / 3 / 4$ / & 0.2 & 6.8 & -10.9 & -3.1 & -2.7 & -2.6 & -2.8 & -4.8 & -4.2 \\
\hline Broad money $5 /$ & 17.0 & 14.4 & 16.8 & 19.6 & 19.1 & 16.2 & 13.9 & 14.6 & 14.0 \\
\hline Including foreign currency deposits & 13.1 & 16.7 & 16.3 & 18.2 & 17.8 & 15.3 & 13.5 & 13.8 & 14.0 \\
\hline M1 5/ & 16.0 & 12.7 & 16.8 & 18.7 & 20.1 & 16.2 & 13.7 & 13.6 & 9.9 \\
\hline M0 5/ & 8.9 & 7.1 & 10.1 & 14.3 & 12.8 & 12.2 & 12.1 & 8.7 & 10.1 \\
\hline Quasi money & 10.0 & 15.5 & 16.8 & 20.1 & 18.5 & 16.7 & 14.1 & 14.7 & 16.5 \\
\hline Reserve money & 8.5 & 9.2 & 13.3 & 17.1 & 14.4 & 18.7 & 13.7 & 11.4 & 14.1 \\
\hline Net foreign assets of PBC 6/ & 2.2 & 11.4 & 8.7 & 17.4 & 19.7 & 21.3 & 20.2 & 29.8 & 34.4 \\
\hline Net domestic assets of PBC 6/ & 6.4 & -2.2 & 4.6 & -0.3 & -5.3 & -2.5 & -6.4 & -18.4 & -20.3 \\
\hline \multicolumn{10}{|l|}{ Reserve ratios: $7 /$} \\
\hline Required reserves & 6.0 & 6.0 & 6.0 & 7.0 & 7.0 & 7.5 & 7.5 & 7.5 & 7.5 \\
\hline Excess reserves & 7.3 & 6.1 & 5.4 & 5.5 & 4.3 & 3.8 & 3.6 & 5.3 & 4.2 \\
\hline \multicolumn{10}{|l|}{ Memorandum items: } \\
\hline Money multiplier & 3.7 & 4.0 & 4.1 & 4.2 & 4.6 & 4.6 & 4.6 & 4.3 & 4.6 \\
\hline Forex deposits of residents (US\$ billion) & 128.3 & 134.9 & 150.7 & 148.7 & 146.8 & 151.1 & 155.9 & 153.0 & 160.9 \\
\hline In percent of total deposits & 8.1 & 7.3 & 6.9 & 5.8 & 5.4 & 5.4 & 5.5 & 5.2 & 5.2 \\
\hline Forex loans of residents (US\$ billion) & 61.2 & 80.7 & 102.8 & 131.3 & 140.2 & 134.6 & 134.6 & 135.3 & 149.7 \\
\hline
\end{tabular}

Sources: The People's Bank of China; and staff calculations.

1/ Starting 2002, includes foreign currency operations of domestic financial institutions and domestic operations of foreign banks. In addition, some items were moved from Other Items Net to Net Credit to Government.

$2 /$ Twelve-month change as a percent of beginning-period stock of monetary liabilities.

3/ 2002 growth rates are based on data that exclude the revisions made in 2002 (see footnote 1).

4/ The growth rates are corrected for the transfer of NPLs from banks to the AMCs.

$5 /$ The growth rates are based on official announcements, which correct for the definitional changes in the series.

6/ Twelve-month change as a percent of beginning-period reserve money stock.

7/ In percent of total bank deposits. 2003-04 excess reserve figures are averages provided by the authorities. 
Table 6. China: State Budgetary Operations 1/

\begin{tabular}{|c|c|c|c|c|c|c|c|}
\hline & \multirow{2}{*}{2000} & \multirow[t]{2}{*}{2001} & \multirow[t]{2}{*}{2002} & \multirow[t]{2}{*}{2003} & \multirow{2}{*}{$\frac{2004}{\text { Prel. }}$} & \multicolumn{2}{|c|}{2005} \\
\hline & & & & & & Budget & Proj. \\
\hline & \multicolumn{7}{|c|}{ (In billions of yuan) } \\
\hline Total revenue & 1,366 & 1,657 & 1,916 & 2,194 & 2,657 & 2,947 & 3,077 \\
\hline Tax revenue $2 /$ & 1,257 & 1,529 & 1,763 & 2,002 & 2,414 & 2,675 & 2,858 \\
\hline Taxes on income and profits & 262 & 391 & 472 & 476 & 593 & 658 & 702 \\
\hline Taxes on goods and services & 847 & 977 & 1,111 & 1,299 & 1,535 & 1,692 & 1,834 \\
\hline Other taxes & 149 & 162 & 180 & 227 & 287 & 325 & 322 \\
\hline Nontax revenue & 109 & 127 & 154 & 192 & 243 & 272 & 219 \\
\hline Total expenditure & 1,691 & 1,958 & 2,272 & 2,527 & 2,889 & 3,278 & 3,348 \\
\hline Current expenditure, of which: & 1,316 & 1,564 & 1,820 & 2,035 & 2,393 & 2,754 & 2,813 \\
\hline Administration and defense & 396 & 481 & 576 & 655 & 766 & 853 & 871 \\
\hline Culture, education, public health, and science & 286 & 350 & 415 & 471 & 537 & 625 & 638 \\
\hline Pensions and social welfare relief & 153 & 195 & 264 & 266 & 309 & 341 & 349 \\
\hline Subsidies & 133 & 104 & 90 & 111 & 139 & 146 & 149 \\
\hline Interest & 73 & 79 & 68 & 93 & 74 & 82 & 83 \\
\hline Capital expenditure & 300 & 351 & 411 & 452 & 465 & 494 & 504 \\
\hline Unrecorded expenditures $3 /$ & 75 & 43 & 40 & 39 & 31 & 31 & 31 \\
\hline Overall balance & -325 & -301 & -355 & -332 & -232 & -331 & -271 \\
\hline Financing & 325 & 301 & 355 & 332 & 232 & 331 & 271 \\
\hline Domestic (net, residual) & 311 & 294 & 349 & 328 & 230 & 329 & 269 \\
\hline \multirow[t]{2}{*}{ Foreign (net) } & 14 & 7 & 6 & 5 & 2 & 2 & 2 \\
\hline & \multicolumn{7}{|c|}{ (In percent of GDP) } \\
\hline Total revenue & 15.3 & 17.0 & 18.2 & 18.7 & 19.4 & 18.8 & 19.6 \\
\hline Tax revenue $2 /$ & 14.1 & 15.7 & 16.8 & 17.1 & 17.6 & 17.1 & 18.2 \\
\hline Taxes on income and profits & 2.9 & 4.0 & 4.5 & 4.1 & 4.3 & 4.2 & 4.5 \\
\hline Taxes on goods and services & 9.5 & 10.0 & 10.6 & 11.1 & 11.2 & 10.8 & 11.7 \\
\hline Other taxes & 1.7 & 1.7 & 1.7 & 1.9 & 2.1 & 2.1 & 2.1 \\
\hline Nontax revenue & 1.2 & 1.3 & 1.5 & 1.6 & 1.8 & 1.7 & 1.4 \\
\hline Total expenditure & 18.9 & 20.1 & 21.6 & 21.5 & 21.1 & 20.9 & 21.4 \\
\hline Current expenditure, of which: & 14.7 & 16.1 & 17.3 & 17.3 & 17.5 & 17.6 & 18.0 \\
\hline Administration and defense & 4.4 & 4.9 & 5.5 & 5.6 & 5.6 & 5.4 & 5.6 \\
\hline Culture, education, public health, and science & 3.2 & 3.6 & 3.9 & 4.0 & 3.9 & 4.0 & 4.1 \\
\hline Pensions and social welfare relief & 1.7 & 2.0 & 2.5 & 2.3 & 2.3 & 2.2 & 2.2 \\
\hline Subsidies & 1.5 & 1.1 & 0.9 & 0.9 & 1.0 & 0.9 & 1.0 \\
\hline Interest & 0.8 & 0.8 & 0.6 & 0.8 & 0.5 & 0.5 & 0.5 \\
\hline Capital expenditure & 3.3 & 3.6 & 3.9 & 3.9 & 3.4 & 3.2 & 3.2 \\
\hline Unrecorded expenditures 3 / & 0.8 & 0.4 & 0.4 & 0.3 & 0.2 & 0.2 & 0.2 \\
\hline Overall balance & -3.6 & -3.1 & -3.4 & -2.8 & -1.7 & -2.1 & -1.7 \\
\hline Financing & 3.6 & 3.1 & 3.4 & 2.8 & 1.7 & 2.1 & 1.7 \\
\hline Domestic (net, residual) & 3.5 & 3.0 & 3.3 & 2.8 & 1.7 & 2.1 & 1.7 \\
\hline Foreign (net) & 0.2 & 0.1 & 0.1 & 0.0 & 0.0 & 0.0 & 0.0 \\
\hline \multicolumn{8}{|l|}{ Memorandum items: } \\
\hline VAT refunds to exporters (in billions of yuan) & -105 & -108 & -115 & -199 & -348 & -380 & -380 \\
\hline Primary balance & -2.8 & -2.3 & -2.7 & -2.0 & -1.1 & -1.6 & -1.2 \\
\hline Government debt & 22.2 & 23.6 & 25.1 & 25.6 & 23.6 & 23.4 & 22.3 \\
\hline Domestic & 17.7 & 19.4 & 21.2 & 21.9 & 20.4 & 20.7 & 19.6 \\
\hline External & 4.5 & 4.2 & 4.0 & 3.7 & 3.1 & 2.7 & 2.7 \\
\hline Budget balance (authorities' definition) & -2.8 & -2.5 & -3.0 & -2.5 & -1.5 & -1.9 & -1.5 \\
\hline Nominal GDP (in billions of yuan) & 8,947 & 9,731 & 10,517 & 11,739 & 13,688 & 15,665 & 15,665 \\
\hline
\end{tabular}

Sources: Ministry of Finance; People's Bank of China; National Bureau of Statistics; and staff estimates.

$1 /$ The coverage is central government, provinces, municipalities, and counties.

2/ Tax revenues are net of refunds for VAT paid on inputs. As of end-2003, refunds amounting to roughly RMB 250 billion

had been claimed but not paid.The IMF definition is not adjusted for tax refund arrears in the absence of adequate data.

3 / Includes external borrowing excluded from the budget and unbudgeted "fiscal stimulus" spending (see Table 7). 
Table 7. China: Official and IMF Budget Definitions

\begin{tabular}{|c|c|c|c|c|c|c|c|}
\hline & \multirow{2}{*}{2000} & \multirow[t]{2}{*}{2001} & \multirow[t]{2}{*}{2002} & \multirow[t]{2}{*}{2003} & \multirow{2}{*}{$\frac{2004}{\text { Prel. }}$} & \multicolumn{2}{|c|}{2005} \\
\hline & & & & & & Budget & Proj \\
\hline & \multicolumn{7}{|c|}{ (In billions of yuan) } \\
\hline Revenue (official definition) $1 /$ & 1,338 & 1,639 & 1,890 & 2,172 & 2,636 & 2,926 & 3,056 \\
\hline \multicolumn{8}{|l|}{ Plus : } \\
\hline Subsidies to loss-making SOEs $2 /$ & 28 & 30 & 26 & 23 & 22 & 22 & 22 \\
\hline \multicolumn{8}{|l|}{ Minus : } \\
\hline Privatization proceeds & 0 & 12 & 0 & 0 & 0 & 0 & 0 \\
\hline Revenue (IMF definition) & 1,366 & 1,657 & 1,916 & 2,194 & 2,657 & 2,947 & 3,077 \\
\hline Expenditure (official definition) & 1,588 & 1,884 & 2,205 & 2,465 & 2,836 & 3,226 & 3,296 \\
\hline \multicolumn{8}{|l|}{ Plus: } \\
\hline Subsidies to loss-making SOEs $2 /$ & 28 & 30 & 26 & 23 & 22 & 22 & 22 \\
\hline External borrowing excluded from the budget $2 /$ & 13 & 3 & 15 & 14 & 16 & 16 & 16 \\
\hline $\begin{array}{l}\text { Unrecorded fiscal stimulus spending 2/ } \\
\text { (onlending to local governments) }\end{array}$ & 62 & 40 & 25 & 25 & 15 & 15 & 15 \\
\hline Expenditure (IMF definition) & 1,691 & 1,958 & 2,272 & 2,527 & 2,889 & 3,278 & 3,348 \\
\hline Balance (official definition) & -250 & -246 & -315 & -293 & -201 & -300 & -240 \\
\hline Balance (IMF definition) & -325 & -301 & -355 & -332 & -232 & -331 & -271 \\
\hline & \multicolumn{7}{|c|}{ (In percent of GDP) } \\
\hline Revenue (official definition) & 15.0 & 16.8 & 18.0 & 18.5 & 19.3 & 18.7 & 19.5 \\
\hline Revenue (IMF definition) & 15.3 & 17.0 & 18.2 & 18.7 & 19.4 & 18.8 & 19.6 \\
\hline Expenditure (official definition) & 17.7 & 19.4 & 21.0 & 21.0 & 20.7 & 20.6 & 21.0 \\
\hline Expenditure (IMF definition) & 18.9 & 20.1 & 21.6 & 21.5 & 21.1 & 20.9 & 21.4 \\
\hline Balance (official definition) & -2.8 & -2.5 & -3.0 & -2.5 & -1.5 & -1.9 & -1.5 \\
\hline Balance (IMF definition) & -3.6 & -3.1 & -3.4 & -2.8 & -1.7 & -2.1 & -1.7 \\
\hline \multicolumn{8}{|l|}{ Memorandum item: } \\
\hline Nominal GDP (in billions of yuan) & 8,947 & 9,731 & 10,517 & 11,739 & 13,688 & 15,665 & 15,665 \\
\hline
\end{tabular}

Sources: Ministry of Finance; and staff calculations.

1/ Tax revenues are net of refunds for VAT paid on inputs. As of end-2003, refunds amounting to roughly RMB 250 billion had been claimed but not paid.The IMF definition is not adjusted for tax refund arrears in the absence of adequate data.

2/ Assumption for 2005. 
Table 8. China: Illustrative Medium-Term Scenario

\begin{tabular}{|c|c|c|c|c|c|c|c|c|c|}
\hline & 2002 & 2003 & 2004 & 2005 & 2006 & 2007 & 2008 & 2009 & 2010 \\
\hline & \multicolumn{9}{|c|}{ (Percent change) } \\
\hline Real GDP & 8.3 & 9.5 & 9.5 & 9.0 & 8.5 & 8.0 & 7.5 & 7.0 & 7.0 \\
\hline Real domestic demand & 7.9 & 9.7 & 8.7 & 8.0 & 8.6 & 8.3 & 7.4 & 6.8 & 6.9 \\
\hline Consumer prices (average) & -0.8 & 1.2 & 3.9 & 3.0 & 3.2 & 3.4 & 3.6 & 3.8 & 4.0 \\
\hline & \multicolumn{9}{|c|}{ (In percent of GDP) } \\
\hline Total capital formation & 40 & 44 & 45 & 46 & 46 & 46 & 46 & 45 & 45 \\
\hline Gross national saving & 43 & 47 & 49 & 52 & 52 & 51 & 51 & 50 & 50 \\
\hline Fiscal balance & -3.3 & -2.8 & -1.7 & -1.7 & -1.5 & -1.4 & -1.2 & -1.1 & -1.0 \\
\hline Revenue & 18.2 & 18.7 & 19.4 & 19.6 & 19.0 & 19.3 & 19.5 & 19.7 & 20.0 \\
\hline Expenditure & 21.5 & 21.5 & 21.1 & 21.4 & 20.5 & 20.7 & 20.7 & 20.8 & 21.0 \\
\hline Current account balance & 2.8 & 3.2 & 4.2 & 6.0 & 5.7 & 5.3 & 5.2 & 4.9 & 4.5 \\
\hline & \multicolumn{9}{|c|}{ (In billions of U.S. dollars) } \\
\hline Current account balance & 35 & 46 & 69 & 114 & 121 & 125 & 137 & 143 & 147 \\
\hline Trade balance & 44 & 45 & 59 & 96 & 90 & 89 & 104 & 121 & 138 \\
\hline Exports & 326 & 438 & 593 & 750 & 901 & 1,064 & 1,242 & 1,443 & 1,672 \\
\hline (Percent change) & 22 & 35 & 35 & 26 & 20 & 18 & 17 & 16 & 16 \\
\hline Imports & 281 & 394 & 534 & 654 & 811 & 974 & 1,138 & 1,321 & 1,534 \\
\hline (Percent change) & 21 & 40 & 36 & 22 & 24 & 20 & 17 & 16 & 16 \\
\hline Capital and financial account, net 1/ & 32 & 53 & 111 & 96 & 39 & 30 & 13 & 7 & 3 \\
\hline Errors and omissions & 8 & 18 & 27 & $\ldots$ & $\ldots$ & $\ldots$ & $\ldots$ & $\ldots$ & $\ldots$ \\
\hline Change in reserves (- indicates increase) & -76 & -117 & -206 & -210 & -160 & -155 & -150 & -150 & -150 \\
\hline \multicolumn{10}{|l|}{ Memorandum items: } \\
\hline External debt (official definition) 2/ & 171 & 194 & 229 & 303 & 371 & 438 & 502 & 561 & 609 \\
\hline (Percent of GDP) & 13 & 14 & 14 & 16 & 17 & 19 & 19 & 19 & 19 \\
\hline Nominal GDP (In billions of RMB) & 10,517 & 11,739 & 13,688 & 15,665 & 17,541 & 19,588 & 21,815 & 24,230 & 26,963 \\
\hline
\end{tabular}

Sources: Data provided by the Chinese authorities; and staff estimates and projections.

1/ Excludes errors and omissions up until 2004, included errors and omissions from 2005 onwards.

2 / The coverage and classification of official external debt data were modified in 2001. Categories of debt previously not covered have since been included. 


\section{China-Debt SustainabiLity Analysis}

1. An analysis of the sustainability of China's government debt based on the standard Fund framework does not suggest major difficulties over the next few years; however, over the longer term, large quasi-fiscal liabilities and rising expenditure pressures are key sources of potential fiscal vulnerability. The standard Fund framework cannot be easily extended to longer horizons because data limitations preclude precise estimates of quasi-fiscal liabilities; there are also considerable uncertainties in trying to gauge the magnitude of potential expenditure pressures over the longer term.

\section{China's official government debt is low, but would be significantly larger if} quasi-fiscal liabilities were included. Official data show that the stock of explicit government debt stood at about 24 percent of GDP at end-2004. ${ }^{1}$ Contingent liabilities include nonperforming loans (NPLs) in the banking system, unfunded pension obligations, and external borrowings by state-owned enterprises (SOEs). Owing to lack of data, this debt sustainability analysis only includes estimated losses from reported NPLs and the minimum transition costs of shifting to a viable pension system. ${ }^{2}$ However, potential data weaknesses and inevitable problems in implementing new prudential regimes suggest that the scale of problem loans may be higher. Transition costs of the pension reform could also be substantially higher, depending on the magnitude of changes to the pension parameters. Liabilities, direct and contingent, of local governments are not included, as no information is available. On the other hand, China could potentially use its substantial stock of state assets to finance government debt obligations. Moreover, potential pressures on spending are expected to intensify over time, especially due to an ageing population; however, their fiscal impact would mainly fall outside of the medium-term horizon covered here.

\footnotetext{
${ }^{1}$ This estimated stock includes regular issues of bonds to finance the central government's budget deficits, as well as the bonds issued to recapitalize the four state-owned commercial banks in 1998 and bonds used for on-lending to local governments.

2 Based on authorities' data, the stock of NPLs is estimated to amount to about 30 percent of GDP at end-2004 (also including the stock of NPLs originally transferred to AMCs, amounting to about 10 percent of 2004 GDP). In the DSA exercise shown in Table I.1, it is assumed that NPLs have a recovery rate of about 20 percent; for the projections of future NPLs, it is assumed that 16 percent of new loans will eventually become nonperforming. Unfunded pension liabilities are assumed to be about 7 percent of GDP and covered by the budget in 2006; interest will also be paid on these and the bonds issued to cover NPLs as of 2007.
} 
3. The debt sustainability analysis is based on the staff's macroeconomic projections and on the authorities' medium-term fiscal framework. Key assumptions include:

- $\quad$ GDP growth is projected to gradually decelerate and stabilize at 7 percent a year from 2009.

- $\quad$ The nominal value of the deficit will be held constant at its projected 2005 level, implying a decline in the primary deficit of about $1 / 4$ percent of GDP a year.

- $\quad$ The average domestic real interest rate increases gradually to 3 percent within five years, reflecting gradual liberalization of the financial sector. ${ }^{3}$

4. Under these assumptions, the debt-to-GDP ratio would have a step increase in 2006 (to about 52 percent of GDP), but then would resume a declining path over the projection period (Table I.1). The sensitivity analysis suggests that fiscal sustainability may not be a major concern over the next few years, provided that structural reforms continue to be implemented. To take into account the uncertainties about the future macroeconomic conditions, spending needs, and the actual level of contingent liabilities, the effects of a higher real interest rate, lower growth, wider primary deficit, and a higher stock of contingent liabilities were simulated. Isolated or combined temporary adverse shocks on these key variables would only increase the debt-to-GDP ratio in the short run.

- Individual temporary shocks. A temporarily lower GDP growth rate would increase the debt-to-GDP ratio to about 54 percent in 2006 (scenario A3), and a higher real interest rate would increase the ratio to above 58 percent in 2007 (scenario B1), but these ratios would then resume a declining path as in the baseline scenario. ${ }^{4}$

\footnotetext{
${ }^{3}$ Given the existing interest rates and maturity structure of public debt, the projected return of modest inflation produces a decline in the aggregate effective real interest rate during the projection period.

${ }^{4}$ The standard deviations and means for all variables have been calculated on the basis of the last 10 years.
} 
- Combined temporary shocks. Should GDP growth be slower, the real interest rate higher, and public spending more expansionary all at the same time (by one standard deviation), the debt-to-GDP ratio would increase to about 60 percent in 2007 and then decline (scenario B4).

- Higher initial public debt stock. If debt-creating flows were to be 10 percentage points of GDP higher in 2006, the debt-to-GDP ratio would reach 63 percent in 2006, but would fall to below 58 percent of GDP by 2010 (scenario B5). 
Table I.1. China: Public Sector Debt Sustainability Framework, 1999-2009

(In percent of GD, unless otherwise indicated)

\begin{tabular}{|c|c|c|c|c|c|c|c|c|c|c|c|c|c|}
\hline & & & Actual & & & & & & & Project & tions & & \\
\hline & 2000 & 2001 & 2002 & 2003 & 2004 & & & 2005 & 2006 & & 2008 & 2009 & 2010 \\
\hline Public sector debt and contingent debt 1 / & $\ldots$ & $\ldots$ & $\ldots$ & $\ldots$ & 48.8 & & & 46.6 & 51.9 & 50.8 & 49.7 & 48.7 & 47.5 \\
\hline \multirow[t]{2}{*}{ Contingent debt (NPLs and pensions) 2/ } & $\ldots$ & $\cdots$ & $\ldots$ & $\cdots$ & 25.2 & & & 24.3 & 30.5 & 30.2 & 29.9 & 29.8 & 29.5 \\
\hline & & & & & & & & \multicolumn{6}{|c|}{ I. Baseline Projections } \\
\hline $\begin{array}{l}\text { Public sector debt } \\
\mathrm{o} / \mathrm{w} \text { foreign-currency denominated }\end{array}$ & $\begin{array}{r}22.2 \\
4.5\end{array}$ & $\begin{array}{r}23.6 \\
4.2\end{array}$ & $\begin{array}{r}25.1 \\
4.0\end{array}$ & $\begin{array}{r}25.5 \\
3.6\end{array}$ & $\begin{array}{r}23.6 \\
3.1\end{array}$ & & & $\begin{array}{r}22.3 \\
2.7\end{array}$ & $\begin{array}{r}21.5 \\
2.5\end{array}$ & $\begin{array}{r}20.6 \\
2.2\end{array}$ & $\begin{array}{r}19.7 \\
2.0\end{array}$ & $\begin{array}{r}\mathbf{1 8 . 9} \\
1.8\end{array}$ & $\begin{array}{r}\mathbf{1 8 . 0} \\
1.6\end{array}$ \\
\hline Change in public sector debt & 1.9 & 1.4 & 1.5 & 0.3 & -1.9 & & & -1.2 & -0.8 & -0.9 & -0.9 & -0.8 & -0.9 \\
\hline $\begin{array}{l}\text { Identified debt-creating flows }(4+7+12) \\
\text { Pcimw }\end{array}$ & 1.9 & 1.3 & 1.6 & 0.2 & -1.3 & & & -0.8 & -0.7 & -0.7 & -0.7 & -0.6 & -0.7 \\
\hline $\begin{array}{l}\text { Primary deficit } \\
\text { Revenue and grants }\end{array}$ & $\begin{array}{r}2.8 \\
15.3\end{array}$ & $\begin{array}{r}2.3 \\
17.0\end{array}$ & $\begin{array}{r}2.7 \\
18.2\end{array}$ & $\begin{array}{r}2.0 \\
18.7\end{array}$ & $\begin{array}{c}1.1 \\
19.4\end{array}$ & & & $\begin{array}{r}1.2 \\
19.6\end{array}$ & $\begin{array}{r}0.9 \\
19.0\end{array}$ & $\begin{array}{c}0.8 \\
19.3\end{array}$ & $\begin{array}{r}0.6 \\
19.5\end{array}$ & $\begin{array}{r}0.5 \\
19.7\end{array}$ & $\begin{array}{r}0.4 \\
20.0\end{array}$ \\
\hline Primary (noninterest) expenditure & 18.1 & 19.3 & 21.0 & 20.7 & 20.6 & & & 20.8 & 19.9 & 20.1 & 20.1 & 20.2 & 20.4 \\
\hline Automatic debt dynamics $3 /$ & -0.9 & -1.0 & -1.1 & -1.8 & -2.4 & & & -2.0 & -1.6 & -1.5 & -1.3 & -1.1 & -1.1 \\
\hline Contribution from interest rate/growth differential 4 / & -0.9 & -1.0 & -1.1 & -1.8 & -2.4 & & & -2.0 & -1.6 & -1.5 & -1.3 & -1.1 & -1.1 \\
\hline Of which contribution from real interess r rate & 0.6 & 0.6 & 0.7 & 0.3 & -0.3 & & & -0.1 & 0.1 & 0.1 & 0.1 & 0.1 & 0.1 \\
\hline Of which contribution from real GDP growth & -1.5 & -1.5 & -1.8 & -2.1 & -2.1 & & & -1.9 & -1.7 & -1.6 & -1.4 & -1.3 & -1.2 \\
\hline Contribution from exchange rate depreciation $5 /$ & 0.0 & 0.0 & 0.0 & 0.0 & 0.0 & & & & & & & & \\
\hline Other identified debt-creating flows & 0.0 & 0.0 & 0.0 & 0.0 & 0.0 & & & 0.0 & 0.0 & 0.0 & 0.0 & 0.0 & 0.0 \\
\hline $\begin{array}{l}\text { Privatization receipts (negative) } \\
\text { Pantions }\end{array}$ & 0.0 & 0.0 & 0.0 & 0.0 & 0.0 & & & 0.0 & 0.0 & 0.0 & 0.0 & 0.0 & 0.0 \\
\hline $\begin{array}{l}\text { Recognition of implicit or contingent liabilities } \\
\text { Other (specify. e. bank recapitalization) }\end{array}$ & 0.0 & 0.0 & 0.0 & 0.0 & 0.0 & & & 0.0 & 0.0 & 0.0 & 0.0 & 0.0 & 0.0 \\
\hline $\begin{array}{l}\text { Other (specify, e.g. bank recapitialization) } \\
\text { Residual, including asset changes (2-3) } 6 /\end{array}$ & $\begin{array}{l}0.0 \\
0.0\end{array}$ & $\begin{array}{l}0.0 \\
0.1\end{array}$ & $\begin{array}{r}0.0 \\
-0.1\end{array}$ & $\begin{array}{l}0.0 \\
0.1\end{array}$ & $\begin{array}{r}0.0 \\
-0.6\end{array}$ & & & $\begin{array}{r}0.0 \\
-0.4\end{array}$ & $\begin{array}{r}0.0 \\
-0.1\end{array}$ & $\begin{array}{r}0.0 \\
-0.2\end{array}$ & $\begin{array}{r}0.0 \\
-0.2\end{array}$ & $\begin{array}{r}0.0 \\
-0.2\end{array}$ & $\begin{array}{c}0.0 \\
-0.3\end{array}$ \\
\hline Public sector debt-to-revenue ratio $1 /$ & 145.5 & 138.9 & 137.9 & 136.2 & 121.3 & & & 113.6 & 113.0 & 106.8 & 101.3 & 95.9 & 89.9 \\
\hline $\begin{array}{l}\text { Gross financing need } 7 / \\
\text { in billingnff }\end{array}$ & $\begin{array}{r}5.9 \\
6.3\end{array}$ & $\begin{array}{r}5.8 \\
683\end{array}$ & $\begin{array}{r}6.3 \\
799\end{array}$ & $\begin{array}{r}5.8 \\
82.7\end{array}$ & 4.6 & & & $\begin{array}{r}4.5 \\
846\end{array}$ & 4.2 & $\begin{array}{r}4.0 \\
0.4\end{array}$ & $\begin{array}{r}3.7 \\
077\end{array}$ & 3.5 & $\begin{array}{r}3.3 \\
1365\end{array}$ \\
\hline in billions of U.S. dollars & 63.3 & 68.3 & 79.9 & 82.7 & 76.1 & $\begin{array}{c}10 \text {-Year } \\
\text { Historical }\end{array}$ & $\begin{array}{l}10 \text {-Year } \\
\text { Standard }\end{array}$ & 84.6 & 89.0 & 93.4 & 97.7 & 102.1 & 106.5 \\
\hline Key Macroeconomic and Fiscal Assumptions & & & & & & Average & Deviation & & & & & & \\
\hline Real GDP growth (in percent) & 8.1 & 7.5 & 8.3 & 9.5 & 9.5 & 8.7 & 1.1 & 9.0 & 8.5 & 8.0 & 7.5 & 7.0 & 7.0 \\
\hline Average nominal interest rate on public debt (in percent) $8 /$ & 4.4 & 4.0 & 2.9 & 3.6 & 2.5 & 5.2 & 2.2 & 2.6 & 3.0 & 3.1 & 3.2 & 3.4 & \\
\hline Average real interest rate (nominal rate minus change in GDP defflator, in percent) & 3.4 & 2.8 & 3.2 & 1.6 & -1.0 & 2.9 & 4.8 & -0.4 & 0.5 & 0.6 & 0.7 & 0.9 & 1.0 \\
\hline Inflation rate (GDP deflator, in percent) & 0.9 & 1.2 & -0.3 & 2.1 & 3.5 & 2.3 & 4.6 & 3.0 & 2.5 & 2.5 & 2.5 & 2.5 & 2.5 \\
\hline Growth of real primary spending (deflated by GDP defflator, in percent) & 10.9 & 14.7 & 17.7 & 8.0 & 11.9 & 14.1 & 6.6 & 12.6 & 4.5 & 9.7 & 9.0 & 8.8 & 9.6 \\
\hline Primary deficit & 2.8 & 2.3 & 2.7 & 2.0 & 1.1 & 2.0 & 0.8 & 1.2 & 0.9 & 0.8 & 0.6 & 0.5 & 0.4 \\
\hline \multirow{2}{*}{\multicolumn{8}{|c|}{ A. Alternative Scenarios }} & \multicolumn{6}{|c|}{ II. Stress Tests for Public Debt Ratio } \\
\hline & & & & & & & & & & & & & \\
\hline \multicolumn{8}{|l|}{ Al. Key variables are at their historical av } & 47.1 & 54.3 & 54.7 & 55.0 & 55.3 & 55.6 \\
\hline \multicolumn{8}{|c|}{$\begin{array}{l}\text { A2. No policy change (constant primary balance) in } 2005-09 \\
\text { A3. Country-specific shock in 2005, with reduction in GDP growth (relative to baseline) of one standard deviation }\end{array}$} & 47.5 & 53.8 & 53.1 & 52.5 & 52.1 & 52.6 \\
\hline \multicolumn{14}{|l|}{ B. Bound Tests } \\
\hline \multicolumn{8}{|l|}{ B1. Real interest rate is at historical average plus two standard deviations in 2005 and 2006} & 47.5 & 56.1 & 58.4 & 58.1 & 58.3 & 58.7 \\
\hline \multicolumn{8}{|c|}{$\begin{array}{l}\text { B2. Real GDP growth is at historical average minus two standard deviations in } 2005 \text { and } 2006 \\
\text { B3. Primary balance is at historical average minus two standard deviations in } 2005 \text { and } 2006\end{array}$} & $\begin{array}{l}47.5 \\
47.5\end{array}$ & $\begin{array}{ccc}55.0 \\
55.8\end{array}$ & 56.1 & 56.8 & 57.8 & $\begin{array}{r}59.0 \\
579\end{array}$ \\
\hline \multirow{2}{*}{\multicolumn{8}{|c|}{$\begin{array}{l}\text { B4. Combination of B-1-B using one statdard deviation shocks } \\
\text { B5. } 10 \text { percent of GDP increase in other deb-creating flows in } 2005\end{array}$}} & $\begin{array}{l}47.5 \\
47\end{array}$ & 55.8 & $\begin{array}{r}57.5 \\
59.6\end{array}$ & $\begin{array}{r}57.3 \\
584\end{array}$ & $\begin{array}{l}57.5 \\
57\end{array}$ & 57.9 \\
\hline & & & & & & & & 47.5 & 63.1 & 61.5 & 60.1 & 58.9 & 57.7 \\
\hline
\end{tabular}

1/ Indicate coverage of public sector, e.g., general government or nonfinancial public sector. Also whether net or gross debt is used.
$2 /$ For the assumptions, see footnote 3 in the Annex

3/ Derived as $[(\mathrm{r}-\pi(1+\mathrm{g})-\mathrm{g}+\alpha \varepsilon(1+\mathrm{r})](1+\mathrm{g}+\pi+\mathrm{g} \pi))$ times previous period debt ratio, with $\mathrm{r}=$ interest rate; $\pi=$ growth rate of GDP deflator; $\mathrm{g}=$ real GDP growth rate; $\alpha=$ share of foreign-currency denominated debt; and $\varepsilon=$ nominal exchange rate depreciation (measured by increase in local currency value of U.S. dollar).

4/ The real interest rate contribution is derived from the denominator in footnote $2 /$ as $r-\pi(1+g)$ and the real growth contribution as $-g$

and long-term public sector debt, plus short-term debt at end of previous period.

$8 /$ Derived as nominal interest expenditure divided by previous period debt stock. 


\section{China's Fiscal Reforms and TeChnical Assistance}

In recent years, technical assistance has focused on statistical development, banking supervision, economic training, and a comprehensive fiscal program. The attached table lists recent technical assistance missions to China. This annex focuses on the main staff recommendations in the fiscal area and summarizes recent fiscal reforms.

\section{Fiscal Technical Assistance Program}

FAD has largely provided advice on tax policy, tax administration, and budget and treasury reforms in the context of joint UNDP/IMF program (2000-04) recently concluded. The UNDP's final evaluation of the project provided a positive assessment of the Fund's role. A successor project (2005-08) on capacity building to support pro-poor fiscal reform in China was recently signed. The role of the Fund under the new program has been discussed but not yet agreed upon; in the meantime, there is scope for providing TA in a few priority areas, as explained below.

\section{Tax policy}

The scope of the Fund TA work in this area has been quite comprehensive, covering every major tax: the value-added tax (VAT), the business tax, the enterprise income tax (EIT), and the personal income tax (PIT). Some of the TA has also targeted the tax treatment of specific sectors, including the financial sector.

The VAT is currently the most important tax in China from a revenue standpoint. However, it has two unique features: (1) it is a production-type VAT, i.e., credits are not given for the VAT on capital goods; and (2) it excludes most services, which are taxed under a separate business tax. The focus of the Fund's TA advice on the VAT has been on transforming it into a consumption-type VAT (which is now being piloted in three North-East provinces), and bringing the service sector into the VAT net. As there are important revenue and centralprovince intergovernmental implications of the VAT reform, the Fund has paid particular attention to alternative transition strategies.

With respect to income tax, the Fund's TA advice has focused on improving the structure of the enterprise income tax (EIT), including the unification of the regimes applying separately to domestic and foreign enterprises, and rationalizing and reducing the scope of EIT incentives. Steps are underway for EIT unification, to be implemented in 2007. For the personal income tax (PIT), while the present revenue yield is still relatively insignificant, it is important for its distributive implications and revenue consequences over time. Its structure should be streamlined and its rates simplified. The PIT income exemption threshold should also be increased in conjunction with the rate restructuring. 
The liberalization of the financial sector under the WTO commitments has important tax implications, in particular as the financial sector opens up to foreign competition. The Fund's TA advice has covered topics of taxing banks, insurance companies, investment and pension funds, derivatives, and security transactions, allowing tax deductibility of specific loan provisions, and shifting business tax from a gross interest base to a net interest base.

The authorities also intend to streamline and reduce the tax burden on farmers. In this regard, the 2005 budget announced the elimination of the agricultural by 2006, ahead of the original schedule. This reform will have implications for local governments, which collect this tax.

Reflecting priorities in this area, the Fund will be initially involved in the extension of VAT to financial services. ${ }^{1}$

\section{Tax administration}

The authorities have been putting in place the basic building blocks of a modern national tax administration. In this regard, the Fund TA program has aimed at assisting the State Administration of Taxation (SAT) to develop the strategic capacity required for it to manage a national tax system, with assistance provided to both the central and provincial governments. Information technology development has been satisfactorily completed and risk management techniques have been introduced to SAT and to its provincial managers.

The SAT currently operates under an organizational structure based around tax type. This has been found almost universally to be an inefficient way to organize resources, as it leads to duplication of efforts, costly and complex computerization, poor communications, taxpayer service inefficiencies and difficulties in developing technical specialization. The clear trend has been to move away from tax-type structures toward the development of organizations based around common administrative functions, or around taxpayer types in a few cases.

The SAT should adopt a nationally consistent organizational structure. As an initial step, Fund TA would advice on an appropriate structure, its implications and needed changes. There is also a need to strengthen other aspects of SAT operational effectiveness, for example by improving compliance management and developing self-assessment practices.

\section{Public expenditure management}

In order to improve the efficiency of public spending, a number of budget and treasury reforms are being implemented. In the budget area, the budget coverage is being expanded to include extra-budgetary revenue and spending, the budget preparation cycle has been brought forward and extended, and departmental budgets are being implemented. On the treasury

\footnotetext{
${ }^{1}$ Other related areas where technical assistance could be provided, including on revenue forecasting, are covered below.
} 
reform side, a treasury single account (TSA) has been broadly established at the central level and is being rolled out to the provincial level. ${ }^{2}$ Some progress has also been made on macrofiscal policy coordination.

These efforts have been supported by Fund's extensive technical assistance, covering diagnostic missions on budget execution (including on the development of a treasury within the MOF and a TSA), budget preparation, macro-fiscal policy coordination, and budget classification and the underlying accounting framework.

The authorities have also announced their intention to reform the Budget Law, in line with recent Fund TA. Areas of improvements include the clarification of the roles and rights of the legislative and executive in the budget process; restriction on the use of extrabudgetary funds; improvements in the sequencing and timetable for budget preparation; stronger medium-term focus of the budget; and the joint consideration of current and capital budgets.

Work is, however, still needed in the treasury and accounting area, where there are three main concerns. First, while there are valid arguments for using the pilot testing approach favored by the authorities for rolling out a computerized General Financial Management Information System (GFMIS), these pilots should best be developed after the decision is taken on the underlying process reforms and the appropriate IT strategy. Otherwise, there is a risk that communication (and particularly data transfer) between different parts of the system will be compromised. Second, insufficient progress has been made on the chart of accounts, which represents a key requirement for the GFMIS conceptual design. Finally, and more generally, treasury reforms have advanced faster than those in the budget area. For this reason, it is crucial that the adoption of budget classification system in line with international standards - currently on hold — be resumed expeditiously, as this is a key prerequisite for developing an appropriate reporting system.

More recently, the authorities have identified a need to improve macro-fiscal forecasting (both on the revenue and expenditure side) and cash management. The Fund stands ready to assist in both areas.

\section{Intergovernmental fiscal relations}

In recent years, the authorities have become increasingly aware of the need to reform the system of intergovernmental fiscal relations, as imbalances between the center and subnational levels are growing and regional disparities are widening. There is a need to clarify expenditure mandates, including by centralizing some spending responsibilities such as pensions. Revenue sharing and the design of the transfer system also need to be looked at.

\footnotetext{
${ }^{2}$ A standard Treasury Single Account (TSA) is a bank account or a set of linked bank accounts through which the government, including its entities and spending units, transacts all receipts and payments, and consolidates its cash balances. Cash balances held by a government are efficiently centralized through a TSA.
} 
Key considerations should include giving more control over tax rates to local governments, while transfers should be tailored to the delivery of minimum standards of public services. The Fund stands ready to provide TA on the reform of revenue sharing.

There is also growing concern about the fiscal risks building up at the local government level. Local governments, faced with a legal prohibition to borrow, resort to creative financing to fund their expenditures. In line with Fund TA recommendations, at a minimum a fiscal risk register should be established in the treasury to keep track of these liabilities. The possible relaxation of the legal constraints on local government borrowing will need to be preceded by a number of structural reforms, including strengthening the recording and reporting of local government operations and enhancing the accountability and transparency of local government financial management. 
China-Summary of Technical Assistance, 2001-2005

\begin{tabular}{|c|c|c|}
\hline \multicolumn{3}{|c|}{ China_-Summary of Technical Assistance, 2001-2005 } \\
\hline Department & Purpose & Date \\
\hline \multicolumn{3}{|c|}{ Tax system reform } \\
\hline FAD & Mission on VAT and inheritance tax & April 2001 \\
\hline FAD & Mission on tax preference & September 2001 \\
\hline FAD & Mission on financial sector taxation & Aug/Sep 2002 \\
\hline FAD & Mission on personal income tax reform & November 2003 \\
\hline \multicolumn{3}{|c|}{ Tax administration reform } \\
\hline FAD & Missions on computerizations (5) & June 2000-Oct. 2002 \\
\hline FAD & Missions on strategic planning (2) & Nov. 2001-Aug. 2002 \\
\hline FAD & Seminar on strategic planning in Washington & October 2002 \\
\hline FAD & Mission on revenue administration & November 2003 \\
\hline FAD & Review of computerization project & September 2004 \\
\hline \multicolumn{3}{|l|}{ Budget reform } \\
\hline FAD & $\begin{array}{l}\text { Workshop on treasury, government fiscal management } \\
\text { information system }\end{array}$ & February 2001 \\
\hline FAD & $\begin{array}{l}\text { Mission on budget classification, treasury single } \\
\text { account, macro-fiscal coordination, budget preparation }\end{array}$ & November 2001 \\
\hline FAD & $\begin{array}{l}\text { Mission on budget preparation, budget classification, } \\
\text { and treasury reform }\end{array}$ & June 2002 \\
\hline FAD & Mission on budget classification & March 2003 \\
\hline FAD & Workshop on budget and treasury modernization in & $02+1$ on 2002 \\
\hline FAD & $\begin{array}{l}\text { Washington } \\
\text { Mission on treasury and accounting reforms }\end{array}$ & $\begin{array}{l}\text { October } 2003 \\
\text { November } 2003\end{array}$ \\
\hline FAD & Mission on budget law reforms & March 2004 \\
\hline \multicolumn{3}{|c|}{ Intergovernmental fiscal relations } \\
\hline FAD & $\begin{array}{l}\text { Mission intergovernmental relations } \\
\text { Mission on subnational fiscal risks }\end{array}$ & $\begin{array}{l}\text { November } 2002 \\
\text { November } 2003\end{array}$ \\
\hline \multicolumn{3}{|l|}{ Statistics } \\
\hline STA & Seminar on General Data Dissemination System & April 2001 \\
\hline STA & Seminar on money and banking statistics & April 2001 \\
\hline STA & Missions on trade statistics & June 2001-Jan. 2002 \\
\hline STA & Mission on GDDS & Feb./March 2002 \\
\hline STA & Seminar on Balance of Payments & August 2002 \\
\hline STA & Mission on government financial statistics & September 2002 \\
\hline STA & Seminar on GDDS/SDDS in Washington & September 2002 \\
\hline STA & GDDS Review & December 2003 \\
\hline STA & Mission on government financial statistics & January 2005 \\
\hline STA & High level seminar on macroeconomic statistics & January 2005 \\
\hline STA & Mission on monetary and finance statistic & Feb./March 2005 \\
\hline STA & Seminar on International Investment Position & April 2005 \\
\hline
\end{tabular}


China-Summary of Technical Assistance, 2001-2005

\begin{tabular}{|c|c|c|}
\hline \multicolumn{3}{|c|}{ China_-Summary of Technical Assistance, 2001-2005 } \\
\hline Department & Purpose & Date \\
\hline \multicolumn{3}{|c|}{ Monetary Policy and Bank Supervision } \\
\hline MFD & Missions on banking supervision & October 2003 \\
\hline MFD & Bank Restructuring & April 2004 \\
\hline MFD & AML/CFT Issues & September 2003 \\
\hline MFD & AML/CFT Seminar & April 2004 \\
\hline MFD & Mission on AML/CFT & January 2005 \\
\hline \multicolumn{3}{|l|}{ Review of TA } \\
\hline FAD & $\begin{array}{l}\text { Visit to review and reschedule UNDP/IMF/China fiscal } \\
\text { reform TA activities }\end{array}$ & February 2001 \\
\hline FAD/TAS & $\begin{array}{l}\text { Missions for tripartite review of the UNDP/IMF/China } \\
\text { fiscal reform TA activities (2) }\end{array}$ & Jan. 2002, Feb. 2003 \\
\hline MFD & Mission on TA needs in banking sector reform & July 2002 \\
\hline MFD & Mission on TA needs in financial sector & October 2003 \\
\hline FAD & Participation in UNDP/DFID fiscal reform workshop & February 2004 \\
\hline FAD & $\begin{array}{l}\text { Visit to discuss TA needs under UNDP/DFID fiscal } \\
\text { reform project }\end{array}$ & December 2004 \\
\hline \multicolumn{3}{|l|}{ Training } \\
\hline INS & Courses on financial programming and policies (3) & July 2000-June 2002 \\
\hline INS & High-level seminar on banking reform & March 2001 \\
\hline MFD & Capital Account Convertibility & April 2001 \\
\hline MFD & Course on monetary policy and operations & May 2001-June 2002 \\
\hline MFD & Banking Risk Management & July 2001 \\
\hline FAD & Course on public sector expenditure management & June/July 2002 \\
\hline MFD & Central Bank Accounting & November 2002 \\
\hline INS/MFD & High-level seminar on monetary policy transmission & April 2004 \\
\hline INS/MFD & High-level seminar on exchange rate issues & May 2004 \\
\hline STA & Seminar on coordinated portfolio investment survey & April 2004 \\
\hline STA & Seminar on quarterly national accounts & September 2004 \\
\hline MFD & Workshop on Monetary Strategy and Operation & May 2005 \\
\hline
\end{tabular}




\section{China-Fund RELATIONS}

As of May 31, 2005

I. Membership Status: Joined 12/27/45; Article VIII (December 1, 1996)

II. General Resources Account:

SDR Million

Quota

Fund holdings of currency

Reserve position in Fund

\section{SDR Department:}

SDR Million

$\%$ Allocation

Net cumulative allocation

236.80

837.82
$\%$ Quota

100.00

70.31

29.69
Holdings

IV. Outstanding Purchases and Loans: None

V. Financial Arrangements:

$\begin{array}{lcccc}\text { Type } & \text { Approval Date } & \begin{array}{c}\text { Expiration } \\ \text { Date }\end{array} & \begin{array}{c}\text { Amount } \\ \text { Approved } \\ \text { (SDR Million) }\end{array} & \begin{array}{c}\text { Amount Drawn } \\ \text { (SDR Million) }\end{array} \\ \text { Stand-by } & 11 / 12 / 86 & 11 / 11 / 87 & 597.73 & 597.73\end{array}$

VI. Projected Obligations to Fund: None

VII. Exchange Arrangements:

1. China's exchange rate arrangements were most recently notified to the IMF in 1994, when they authorities introduced a unified exchange rate system. In their formal notification the authorities described the new exchange rate system as a unified, market-based, and managed floating regime. Under this regime, the exchange rate of the renminbi is determined in the interbank foreign exchange market. The State Administration of Foreign Exchange (SAFE) of the People's Bank of China (PBC) announces a basic rate for the renminbi against the Hong Kong dollar, the U.S. dollar, the euro, and the yen, based on the weighted average 
exchange rate that prevailed in foreign exchange transactions on the previous day. In the interbank foreign exchange market, daily changes in the value of the renminbi against the U.S. dollar are limited to 0.3 percent on either side of the basic rate, as announced by the PBC. The daily movement of the renminbi against the Hong Kong dollar and the yen is limited to 1 percent on either side of the basic rate (daily movements beyond this limit must be reported). On February 28, 2005, the exchange rate was Y 8.28 per U.S. dollar.

2. China accepted the obligations of Article VIII, Sections 2, 3, and 4 of the Fund's Articles of Agreement on December 1, 1996. There are repatriation and surrender requirements on proceeds from exports and from invisible transactions and current transfers. All enterprises authorized to conduct current account transactions may retain foreign exchange equivalent to 50 percent of their current account foreign exchange earnings in the previous year (effective May 1, 2004, up from 20 percent), except for special purpose transactions, such as donations and international postal remittances, for which the ceiling is 100 percent. They must sell the rest of their foreign exchange earnings to authorized banks. Importers must provide valid proof and commercial bills to obtain foreign exchange. In 1998, new requirements expanded the scope of documentation required for most forms of current transactions and required prior verification of the underlying transactions in some instances (e.g., the customs service must certify the value of imports before banks can provide foreign exchange for payment). There are no measures currently in force that have been determined to be exchange restrictions subject to Fund jurisdiction.

3. Exchange controls continue to apply to many capital transactions. In general, capital account transactions require the approval of government departments who are in charge of foreign exchange flows (including NDRC, MOC, CSRC, and SAFE), however there has been some relaxation of controls in recent years. Effective December 1, 2002, qualified foreign institutional investors (QFIIs) are allowed to invest domestically in A shares, subject to the following restrictions: (i) QFIIs must have minimum experience in the industry (5 years for fund managers; 30 years for insurance companies) and at least US $\$ 10$ billion in assets under management in the latest financial year, and be cleared of any major irregularities in their home market over the past three years; (ii) a QFII that is a bank must be among the top 100 international banks by assets in the latest financial year; (iii) a QFII that is an insurance or a securities company must have a minimum paid-up capital of US $\$ 1$ billion; and (iv) for each QFII, ownership of any Chinese company listed on the Shanghai or Shenzhen stock exchange is limited to 10 percent, and the total shares owned by QFIIs in a single Chinese company cannot exceed 20 percent. QFIIs must set up a special renminbi account with domestic banks and use the services of domestic securities companies. Close-ended QFIIs can only remit capital after three years, in installments of no more than 20 percent of the total each time, and at intervals of one month or more. Other QFIIs can only remit capital after one year, in installments of no more than 20 percent of the total, and at intervals of three months or more. Regarding portfolio investment abroad, foreign exchange funds of insurance companies were allowed to invest in overseas securities markets. This policy has been put into effect and investments have taken place. In addition, as of December 1, 2002, nonresidents are allowed to purchase B shares, which are denominated in U.S. dollars or Hong Kong dollars, using new or existing foreign currency deposits. In 2004, development international financial institutions were approved to raise funds domestically in renminbi for 
domestic use only, while other nonresidents are still not permitted to issue capital or money market securities in the domestic market. The transfer of personal assets abroad by Chinese citizens emigrating overseas or by nonresidents receiving inheritances is also now permitted. Purchases of capital and money market instruments abroad by residents are restricted to banks who can do foreign exchange business and some approved multinational companies. In 2001 , measures were introduced to ease restrictions on the purchase of foreign exchange with RMB for the advance repayment of foreign debts, foreign exchange on-lending and domestic foreign exchange loans. Prior approval from the SAFE is needed for licensed commercial banks to convert foreign exchange into yuan for capital investment purposes, except in some provinces where it was eliminated under a 2001 pilot program. Also, since December 2001, FFEs no longer need SAFE approval to convert foreign currency into yuan for capital investments, and commercial banks are now responsible for verifying the related documents.

4. An annual foreign borrowing plan sets mandatory ceilings for all borrowing by government departments and enterprises (except FFEs which are subject to individual limits negotiated in the investment approval process). The National Development and Reform Commission determines the medium- and long-term external debt quotas, while the SAFE is responsible for short-term external debt quotas. Financial institutions can do business without approval in advance under the quotas, but regular reporting to SAFE of external debts are obligatory. The pre-approval investigation for other institutions covers the financial situation of the enterprise, the need for the loan, and whether the terms of the loan are consistent with the use of the proceeds. For short-term borrowing by financial institutions (less than a year), the amount of borrowing is subject to an overall limit determined by the SAFE on an annual basis (there are also enterprise-specific limits); financial institutions can conduct business within this limit without explicit approval, but must register the borrowing with the SAFE.

5. Regulations on guarantees by residents to nonresidents have the following key features. First, guarantees consist of collateral and pledges in addition to what are commonly known as assurances. Second, prior SAFE approval is required for financing guarantees provided by banks and all guarantees provided by other institutions (with the exception of solely foreign funded enterprises). Prior approval is not required for nonfinancing guarantees provided by banks. Third, both domestic and foreign-currency-denominated guarantees are covered by the regulations. Fourth, the approval process for guarantees is based on prospective guarantors' profits, assets to liabilities, and foreign exchange revenues, etc.

6. China maintains controls on FDI, although it has generally pursued an "open door" policy toward inward FDI. In the case of overseas direct investment, foreign exchange is provided after a SAFE review of sources of foreign exchange funds and an assessment of the investment risk involved, approval by the Ministry of Commerce (MOC), and registration with SAFE. From May, 2005, a pilot program of the reform of overseas investment foreign exchange regulation was expanded country-wide, and the annual quota of total foreign exchange for overseas investment of each province or municipality was increased to $\$ 5$ billion. In the case of inward direct investment, nonresidents can invest in China subject to meeting certain regulations and MOC approval. On April 1, 2002, a new four-tier classification system for foreign investment was introduced, defining activities where foreign 
investment is encouraged, permitted, restricted or banned. In effect, this resulted in the opening up of many industries previously closed to foreign investment, particularly in the services sectors, consistent with China's WTO-related commitments.

7. Domestic financial institutions and firms cannot engage in such derivative transactions for purposes of speculation. However, transactions designed to hedge interest rate or exchange rate risk are possible. All transactions involving derivative instruments under foreign debt items must be registered with SAFE. With respect to the development of a forward foreign exchange market for the renminbi, all banks have been permitted to offer forward transactions involving the renminbi, but the market remains small and proof of an underlying current transaction is required for access to forward cover.

\section{Article IV Consultation:}

8. The Board discussion for the 2004 Article IV consultation was concluded on July 28, 2004 and, for the first time, the staff report was published. China is on the standard 12-month consultation cycle.

\section{Technical Assistance:}

9. Technical assistance provided in 2000 through May 2005 is summarized in Annex II.

\section{Other Visits:}

10. A mid-term staff visit was held in December 2004. Managing Director met with Governor Zhou in Shanghai on March 18, 2005.

\section{Resident Representative:}

11. The resident representative office in Beijing was opened in October 1991. Mr. Ray Brooks is the Senior Resident Representative and Mr. Steve Barnett is the Resident Representative. 


\section{China: STATISTICAL IsSUES}

1. While China's economic statistics are adequate for surveillance purposes, weakness remain in key areas. China has made significant strides in bringing its economic and financial statistics into line with international good practice. In April 2002, China began participation in the Fund's GDDS and its metadata were posted on the Fund's DSBB (the most comprehensive documentation of Chinese economic and financial statistics available in English). The most recent metadata updates were received from the authorities in April 2005. While China's economic statistics are adequate for surveillance purposes, weaknesses remain in the quality of the data, including coverage, frequency and timeliness. The main statistical issues are noted below.

\section{Real sector}

2. Data on the expenditure components of GDP are not available on a quarterly basis. Annual GDP by expenditure is compiled at current and constant 2000 prices, but the constant price estimates are not published. Quarterly data are produced in cumulative form, with minimal revisions of previous data, making it difficult to assess quarterly developments accurately or to make seasonal adjustments. Constant price measures of GDP are also suspect because of deficiencies with the price indices and techniques used to derive the estimates. Nevertheless, the National Bureau of Statistics has made a number of improvements to the range and quality of national accounts data, including quarterly estimates of GDP by industry and estimates of GDP by type of expenditure. Further improvements are intended, including the adoption of the 1993 System of National Accounts, further development of income and expenditure data, and improvements to quarterly GDP estimates. However, no target dates have been set. As in other countries, rapid economic change, including the expansion of the nonstate sector, presents new problems for data compilation. The ability to change the collection of data is restricted by the decentralized nature of the statistical system. Extensive technical assistance has been provided from multilateral and bilateral institutions.

3. Monthly industrial production, retail sales, and fixed investment data also have a shifting base that does not permit the production of a consistent time series. Data revisions tend to be made without publishing the entire revised series. Retail sales and fixed investment data are published only in nominal, not real, terms.

4. Labor market statistics — including employment and wage data — are not comprehensive, and are only available on an annual basis, with considerable lag.

5. Prior to December 2000, the consumer price index was not produced in a time series format, as there were only comparisons between the current month and the previous month, and the current month with the same month of the previous year. For most items, the weights were for the previous year's expenditures with the other weights being updated each month. Technical assistance missions in September 1991, April 1995, and June 1997 dealt with the concepts and methodology of internationally used index formulae. The authorities have received technical assistance and training on price index methodology under a cooperative 
program with Statistics Canada. A technical assistance mission in August 1999 reviewed the methodology to compile fixed-base price indices in test projects in four provinces and found that only in one province the index was adequate. In January 2001, the NBS began to publish an annually-chained Laspeyres price index, which more accurately reflects consumer spending patterns (e.g., the weight of services increased, while the weight of food declined). The number of survey items has been expanded to more than 550 from the previous 325 . The weights of the major CPI components were provided to the staff during the 2001 Article IV mission.

\section{Government finance}

6. Serious data shortcomings continue to hamper fiscal analysis. Budgetary data exclude spending associated with domestic bond proceeds on-lent to local governments and official external borrowing. Also, data on the social and extra budgetary funds are only provided annually and with a long lag. Expenditure classification remains very poor, mainly because data are not classified by economic type. However, the situation should improve with the introduction of a revised budget classification system, starting with the 2007 budget.

7. China has not reported central government and local government budget data for publication in the GFS Yearbook since 2001. No data are provided on government debt or the operations of extrabudgetary funds. The revenue classification does not fully distinguish between revenue and grants, tax and nontax revenue, and current and capital revenue. The presentation of expenditure is by function only and does not comply with international best practice. Following a government finance statistics technical assistance mission earlier this year, the authorities recently - and for the first time - submitted data on general government for 2002 and 2003 for publication in the 2005 edition of the GFS Yearbook.

\section{Monetary accounts}

8. In recent years, improvements have been made in the classification of accounts of the monetary authorities and banking institutions. From 2002, compilation and reporting of monetary data include foreign-currency-denominated accounts of residents and accounts of the branches of foreign banks.

9. The monetary and banking surveys lack sufficient detail with regard to bank claims on the government, hampering the estimation of the fiscal deficit from the financing side. A recent development is that the $\mathrm{PBC}$ has ceased to report separate data on central government deposits in its balance sheet beginning with data of April 2005 because the MOF no longer distinguishes between central and other government deposit accounts. In addition, detailed breakdowns of bank credit extended by industry, and by borrower (including by the various elements of the state and nonstate sectors), are not publicly available. The staff continues to encourage the authorities to report information of this nature for analytical purposes. 
10. Due to the restructuring of the banking sector, new statistical issues have arisen, such as how to record the transfer of non-performing loans to asset management companies, and how to classify these companies in the banking survey. The monetary and financial statistics mission that visited Beijing in early 2005 made recommendations for addressing these issues.

11. The reported net foreign assets position of PBC does not include exchange rate valuation effects nor interest earnings on foreign reserves.

\section{Balance of payments}

12. The State Administration of Foreign Exchange (SAFE) relies on an International Transactions Reporting System" (ITRS) which produces data derived from information on foreign exchange transactions conducted by banks. To supplement the ITRS, SAFE conducts periodic sample surveys to collect data on travel and trade credits, while additional data are collected from reports on balance sheet information from financial institutions and data on portfolio investment and direct investment.

13. The data are compiled (in U.S. dollars) largely in accordance with the fifth edition of the Balance of Payments Manual (BPM5). Semi-annual (January-June) data are compiled and disseminated within four to five months after the end of the reference period while data on an annual basis are disseminated within six months of the end of the reference period. It appears that the authorities may be close to being able to publish quarterly estimates of the balance of payments. Within the current account, component detail is available on goods, services, income, and transfers. Data on the financial account are also available with significant component detail for functional categories, but with limited sectoral breakdown.

14. The Fund has provided extensive technical assistance for China to improve balance of payments and IIP statistics. In August 2002 a seminar was held on Balance of Payments and IIP statistics in Chengdu, China. The coverage of direct investment transactions remains a problematic issue in the Chinese balance of payments and IIP statistics. Data on these transactions, received mainly from the Ministry of Commerce (formerly Ministry of Foreign Trade and Cooperation), apparently do not cover all required elements such as disinvestments, while the direct investment survey developed by SAFE has not provided reliable data. Another issue that has to be addressed by the authorities is to extend verification and auditing programs to reduce measurement errors and ensure the long-term performance of the ITRS. For this purpose regular training programs for staff in the provincial offices of SAFE were recommended. In addition, in January 2003 a legislative guarantee for the improvement of the quality of ITRS reporting entitled "The Checking System on Balance of Payments Reporting Data (experimental)" was promulgated by the SAFE. 
15. The authorities reported that they have been compiling international investment position (IIP) statements for five years (1999-2003) on a trial basis and they are in the process of soliciting comments from experts, including the IMF. Some data categories still need to be improved; therefore, no IIP data have been published so far.

16. The Fund has also provided technical assistance on the coverage, timeliness, and periodicity of China's data on official reserves, reserves-related liabilities, as well as on other external assets and liabilities, financial derivative activities, and other contingent and potential liabilities. In the December 2003 GDDS progress review, the authorities indicated that they had completed the preparatory work for completing the template on international reserves and foreign currency liquidity in accordance with the SDDS and that there were no technical problems remaining. The authorities also noted that the definition and coverage of China's external debt data follow closely the recently-published External Debt Statistics: Guide for Compilers and Users. Such data are compiled monthly but published on a quarterly basis (monthly data have not been provided to Fund staff on a regular basis). Despite an ostensibly modest level of external vulnerability, there remains a need to strengthen external debt monitoring and compilation, while introducing additional transparency in data dissemination. STA will conduct a seminar on external debt statistics in August 2005 as part of the China Training Program for 2005.

17. In April 2004, STA conducted a seminar in Xianyang, Xi An China on the Coordinated Portfolio Investment Survey (CPIS) to explain the concepts and practical issues involved in undertaking the survey. There was active participation in the seminar although no commitment was made at that time to participate in the CPIS.

18. STA held a workshop and a high-level seminar on the use of macroeconomic statistics for policy analysis and decision making in China in January 2005. A STA technical assistance mission on IIP statistics visited Shanghai during April 2005. The tasks of the mission were to conduct a two-day seminar focusing on the importance and usefulness of the IIP and to meet with compilers to provide detailed technical advice on specific issues related to China's IIP.

\section{Data reporting to STA for publications}

19. In June 1999, the PBC resumed reporting monthly monetary data and has agreed to their publication in IFS. These improvements in reporting notwithstanding, a number of breaks remain in the series, and comparable historical data are not available. Balance of payments data are reported on an annual basis for publication in the Balance of Payments Statistics Yearbook and the IFS. 
20. Since 1994, China's Ministry of Finance (MOF) has regularly reported annual GFS data for publication in the GFS Yearbook. The GFS database currently includes data on the central government budget for 1990-2001, and on provincial and local governments for 1995-2001. The MOF also reports annual GFS data for publication in IFS although with substantial delays. Data through 1998, relate to revenue, expenditure, and the deficit/surplus of the central, provincial, county-level, and municipal governments' budgets.

21. Reporting of data to STA for IFS has, in the past, tended to be sporadic and with a considerable time lag. Following the introduction of new reporting arrangements, the timeliness of consumer price, industrial production, trade value, and total GDP data in IFS has improved substantially. However, the range of information is relatively limited, with no data published on producer prices, wages, trade volumes or prices/unit values.

\section{Data dissemination to the public}

22. The publication of a quarterly statistical bulletin by the PBC has significantly improved the timing and coverage of publicly available data on the monetary accounts and the main real sector indicators. However, the monthly statistical publications do not contain many time series (e.g. unemployment) or the disaggregation necessary for analysis. Moreover, several important time series, particularly on the main fiscal variables, are not released in a systematic and timely manner. Extensive annual economic data are available in various statistical yearbooks, but these are published nine months or more after the end of the year. 
China: Table of Common Indicators Required for Surveillance

As OF JUNE 13, 2005

\begin{tabular}{|c|c|c|c|c|c|}
\hline & $\begin{array}{l}\text { Date of latest } \\
\text { observation }\end{array}$ & $\begin{array}{l}\text { Date } \\
\text { received }\end{array}$ & $\begin{array}{c}\text { Frequency of } \\
\text { Data }^{8}\end{array}$ & $\begin{array}{c}\text { Frequency of } \\
\text { Reporting }\end{array}$ & $\begin{array}{l}\text { Frequency of } \\
\text { publication } 8\end{array}$ \\
\hline Exchange Rates & $6 / 13 / 05$ & $6 / 13 / 05$ & $\mathrm{D}$ & $\mathrm{M}^{9}$ & $\mathrm{D}$ \\
\hline International Reserve Assets and Reserve Liabilities of the Monetary Authorities ${ }^{1}$ & April 2005 & $6 / 1 / 05$ & M & M & M \\
\hline Reserve/Base Money & May 2005 & $6 / 10 / 05$ & Q, M & Q, M & Q, M \\
\hline Broad Money & May 2005 & $6 / 10 / 05$ & M & M & M \\
\hline Central Bank Balance Sheet & April 2005 & $6 / 3 / 05$ & M & M & M \\
\hline Consolidated Balance Sheet of the Banking System & May 2005 & $6 / 10 / 05$ & M & M & M \\
\hline Interest Rates $^{2}$ & $6 / 13 / 05$ & $6 / 13 / 05$ & 10 & 10 & 10 \\
\hline Consumer Price Index ${ }^{3}$ & May 2005 & June 2005 & M & M & M \\
\hline Revenue, Expenditure, Balance and Composition of Financing ${ }^{4}-$ General Government ${ }^{5}$ & Mar 2005 & $4 / 13 / 05$ & M & M & A \\
\hline Revenue, Expenditure, Balance and Composition of Financing ${ }^{4}-$ Central Government & Dec 2003 & May 2004 & A & A & A \\
\hline Stocks of Central Government and Central Government-Guaranteed Debt ${ }^{6}$ & Dec 2003 & May 2004 & A & A & A \\
\hline External Current Account Balance & Sept 2004 & Apr 2005 & $\mathrm{~A}, \mathrm{Q}^{11}$ & $\mathrm{~A}, \mathrm{Q}^{11}$ & $A, Q^{11}$ \\
\hline Exports and Imports of Goods and Services & April 2005 & $6 / 10 / 05$ & M & M & M \\
\hline $\mathrm{GDP} / \mathrm{GNP}^{7}$ & Dec 2004 & $1 / 16 / 05$ & A, Q(cumulative) & A, Q(cumulative) & A, Q(cumulative) \\
\hline Gross External Debt & Mar. 2005 & Apr 2005 & $\mathrm{~A}, \mathrm{Q}$ & $\mathrm{A}, \mathrm{Q}$ & $\mathrm{A}, \mathrm{Q}$ \\
\hline
\end{tabular}

${ }^{1}$ Includes reserve assets pledged or otherwise encumbered as well as net derivative positions.

${ }^{2}$ Both market-based and officially-determined, including discount rates, money market rates, rates on treasury bills, notes and bonds.

${ }^{3}$ Only 12 -month growth rates are reported (price indices are not available).

${ }^{4}$ Data on financing (f foreign, domestic bank, and domestic nonbank financing) in not available.

${ }^{5}$ The general government consists of the central government (budgetary funds, extra budgetary funds, and social security funds) and state and local governments.

${ }^{6}$ Including currency and maturity composition.

${ }^{7}$ For real GDP, level data are available only on an annual basis (growth rates are available on a quarterly, cumulative basis)

${ }^{8}$ Daily (D), Weekly (W), Monthly (M), Quarterly (Q), Annually (A); Irregular (I); Not Available (NA).

${ }^{9}$ While officially transmitted on a monthly basis, these data are available from news sources on a daily basis.

${ }^{10}$ Interest rates change only infrequently; these changes are publicly announced.

${ }^{11}$ Data provided semi-annually. 


\section{China-Relations With The WorLd BANK ${ }^{1}$}

1. The World Bank has been active in China since 1980. World Bank commitments to China as of June 30, 2005 totaled about $\$ 38.9$ billion for 263 projects. About 90 of these projects are still under implementation, making China's portfolio the largest in the Bank. World Bank-supported projects are found in almost all parts of China and in many sectors of the economy, with infrastructure (transport, energy, industry, urban development) accounting for more than half of the total portfolio, and agriculture, social sectors (health, education, social protection), environment, and water supply and sanitation comprising the remainder.

2. In FY2005, lending is projected to total about $\$ 1.0$ billion in IBRD loans for nine projects. Given the increased availability of domestic financing - as a result of China's fiscal stimulus policy - and a shift of the government's development program to the central and western areas, the focus of the World Bank's assistance program is now on the poorer and institutionally weaker inland provinces. As a consequence, the amount of lending per project has been scaled back to suit the absorptive capacity of those provinces, leading to a lower lending level compared with the mid-1990s. By sector, the projects to be approved in FY2005 include two for agricultural development in poor rural areas, four for urban environmental improvements in Chongqing, Hunan, Liuzhou and Ningbo, one for transport and trade facilitation in Inner Mongolia, one for renewable energy, and one for managing the Tai Basin. A summary of Bank commitments and disbursement to China is given in Table V.1. Details of the sectoral breakdown of past lending can be found in Table V.2.

3. Over the next two years, lending is expected to range from $\$ 2.0-3.0$ billion, with support provided to economic reform, the development of health, agriculture and infrastructure in the interior provinces and in the provinces of NE China, and urban management and the environment principally in these areas. Since China is no longer borrowing IDA funds, the Bank, in collaboration with the government and the United Kingdom's Department for International Development (DFID), has developed a mechanism to blend grant resources with IBRD loans, resulting in more concessional loans (at an interest rate of about 2 percent) for selected projects in the social and rural sectors. The FY2004 Basic Education Project and FY2005 Poor Rural Communities Development Project were supported by this mechanism. In FY2006 a rural water supply and sanitation project is also expected to benefit from this mechanism.

4. The current World Bank Group Country Assistance Strategy (CAS), covering both lending and non-lending activities, is designed to help China: (i) improve the business environment and accelerate the transition to a market economy, mostly through an array of knowledge transfer activities; (ii) address the needs of the poorer and disadvantaged people and lagging regions, through investment lending in rural development, infrastructure, and the social sectors, as well as analytical and advisory services and training; and (iii) facilitate an environmentally sustainable

\footnotetext{
${ }^{1}$ Prepared by World Bank staff.
} 
development process, through investment lending in natural resource management, watershed rehabilitation and wastewater treatment, energy, global environment projects supported by the Global Environment Facility and Montreal Protocol, and policy work. A new CAS is under preparation.

5. In addition to financial assistance, the provision of non-financial services in the form of technical assistance, policy advice, seminars and training is an essential part of the cooperation program. The government has strongly endorsed Bank efforts to make its non-lending activities more responsive to the country's evolving needs, by having a better balance between detailed studies of issues requiring lengthy technical analysis and quick delivery of briefer policy notes, supplemented by other forms of collaboration such as senior-level workshops. Some recent or upcoming outputs include: support to formulation of the $11^{\text {th }}$ Five-Year Plan; an economic memorandum on managing scarce resources; issues in the management of economic crises (building on previous work on public expenditures, including at the sub-national level, and on the management of fiscal and financial risks); studies of public service unit reforms, national market integration, maximizing rural health contributions to growth and employment, rural social protection, and labor reform; and a financial sector program focused on capital market development, banking reform, infrastructure finance and rural finance. In FY2005, besides continuing support on the $11^{\text {th }}$ Plan, the World Bank has been assisting on, among other things, intergovernmental fiscal and regional development issues (focused particularly on the Northeast), a study of public finance reform for rural development, a poverty assessment as well as major programs of work on the financial sector and rural health.

Representation:

Capital Subscription:

Technical Assistance:
The People's Republic of China assumed China's representation in the World Bank on May 15, 1980.

China holds 4,480 million shares or 2.85 percent of the total authorized capital of the IBRD. Currently, China is fully subscribed.

A technical assistance loan to the People's Bank of China to enhance the central bank's supervision, research, and clearing capabilities was approved in FY1993. A second technical assistance project, approved in the same year, is financing reform-supportive studies and economic research, the strengthening of core agencies responsible for macroeconomic management and local training institutions, and preinvestment support. Technical assistance for economic law reform was approved in FY1995. Fiscal technical assistance, also approved in FY1995, supported the 
Resident Mission:

implementation of a broad range of public sector reforms.

Assistance in bond market development has also been provided. In FY1999, technical assistance projects were approved for reform of accounting, pension and enterprise systems. Further technical assistance support for economic research and preinvestment was also provided in FY1999. A supplemental loan for financial sector technical assistance was approved in FY2001. A large program of technical assistance is currently financed by trust funds from within and outside the Bank, covering economic and financial sector reform, statistical reform, poverty issues, social sectors, debt management, and social security.

A resident IBRD office in Beijing has been in operation since October 1985. In October 1997, responsibility for managing the Bank's total program for China was decentralized to the Beijing office.

International Finance Corporation (IFC):

As of March 31, 2005, IFC has committed financing for 83 projects in China. For these projects IFC has provided US\$673 million: US\$589 million for IFC's own account, and US\$84 million for the account of participating banks. A resident IFC office in Beijing has been in operation since 1992. In July 2000, a joint IFC/World Bank regional office for private sector development was established in Hong Kong SAR, with management of this program decentralized to that office.

IFC's priorities in China include: supporting private sector development in interior provinces; expanding the presence of private enterprises in infrastructure, social services, and environmental technology sectors; and improving the business environment, particularly as it relates to financial markets, private participation in infrastructure, and small and medium enterprises. 
Table V.1. China: IBRD-IDA Lending Activities, FY1981-05 1/ (In millions of U.S. dollars)

\begin{tabular}{|c|c|c|c|c|}
\hline & \multicolumn{2}{|c|}{ Commitments } & \multicolumn{2}{|c|}{ Disbursements } \\
\hline & IDA & IBRD & IDA & IBRD \\
\hline 1981 & 100 & 100 & 0 & 0 \\
\hline 1982 & 60 & 0 & 0 & 0 \\
\hline 1983 & 150 & 463 & 33 & 0 \\
\hline 1984 & 424 & 616 & 134 & 20 \\
\hline 1985 & 442 & 660 & 146 & 236 \\
\hline 1986 & 450 & 687 & 252 & 352 \\
\hline 1987 & 556 & 867 & 361 & 318 \\
\hline 1988 & 640 & 1,054 & 399 & 302 \\
\hline 1989 & 515 & 833 & 549 & 685 \\
\hline 1990 & 590 & 0 & 557 & 569 \\
\hline 1991 & 978 & 602 & 494 & 620 \\
\hline 1992 & 949 & 1,578 & 753 & 618 \\
\hline 1993 & 1,017 & 2,155 & 763 & 813 \\
\hline 1994 & 925 & 2,202 & 869 & 1,057 \\
\hline 1995 & 630 & 2,434 & 659 & 1,555 \\
\hline 1996 & 480 & 2,540 & 891 & 1,328 \\
\hline 1997 & 325 & 2,490 & 722 & 1,405 \\
\hline 1998 & 293 & 2,323 & 596 & 1,497 \\
\hline 1999 & 423 & 1,674 & 614 & 1,412 \\
\hline 2000 & $02 /$ & 1,673 & 420 & 1,408 \\
\hline 2001 & 0 & 788 & 345 & 1,476 \\
\hline 2002 & 0 & 563 & 260 & 1,755 \\
\hline 2003 & 0 & 1,145 & 153 & 1,628 \\
\hline 2004 & 0 & 1,218 & 105 & 1,205 \\
\hline $20053 /$ & 0 & 1,030 & 51 & 871 \\
\hline Total & 9,947 & 29,694 & $10,1264 /$ & 21,130 \\
\hline
\end{tabular}

1/ The financial year (FY) runs from July through June.

2/ As of July 1, 1999, China no longer borrows from IDA.

3/ Lending for 2005 is an estimate for entire year; disbursement numbers are actuals as of May 31, 2005.

4/ IDA disbursements exceed commitments due to changes in the US\$-SDR exchange rate. 
Table V.2. Distribution of Lending, FY 1980-05 1/

Sector

US\$ mn.

Percent No. of Projects

\begin{tabular}{|c|c|c|c|}
\hline Rural devt./poverty alleviation & 10,033 & 25.3 & 66 \\
\hline Industry and energy & 10,214 & 25.8 & 55 \\
\hline Industry/corporate reform & 3,013 & & 20 \\
\hline Energy/renewable energy & 7,201 & & 35 \\
\hline Transport & 10,221 & 25.8 & 55 \\
\hline Human resources & 2,650 & 6.7 & 30 \\
\hline Education & 1,727 & & 19 \\
\hline Health & 923 & & 11 \\
\hline Environment and urban & 5,895 & 14.8 & 43 \\
\hline Environment & 3,256 & & 24 \\
\hline Urban development & 1,818 & & 12 \\
\hline Water supply & 821 & & 7 \\
\hline Technical assistance/public sector & 628 & 1.6 & 14 \\
\hline Total & 39,641 & 100 & 263 \\
\hline
\end{tabular}

1/ FY05 data is an estimate. 


\section{China-Relations With the Asian DeVelopment Bank}

1. The Asian Development Bank's operation in the PRC focuses on a set of four interrelated challenges: (i) promoting pro-poor inclusive economic growth; (ii) building an enabling environment for the private sector and strengthening public sector governance; (iii) fostering regional cooperation to help integrate the PRC into the global economy; and (iv) promoting environmental sustainability.

2. Since China became a member of ADB in 1986, 107 public sector loans totaling $\$ 14.7$ billion and 449 technical assistance projects amounting to $\$ 239.3$ million have been approved as of end-December 2004. In addition, ADB has 11 private sector loans totaling $\$ 171.5$ million in loan and \$134.3 million in equity as of 31 December 2004.

3. Infrastructure, urban development, environmental improvement and rural and agriculture development will remain Government's priority sectors identified for ADB assistance. ADB lending will continue to focus on the central, western and northeastern provinces.

4. The Country Strategy and Program Update (2005 -2007) has programmed a total loan assistance of $\$ 4.6$ billion for the period 2005-2007, amounting to an annual average lending of about $\$ 1.5$ billion. Of this, 59 percent is for the transport sector, 13 percent for the agriculture and natural resources sector, 16 percent for the social infrastructure sector, 9 percent in the energy sector and 3 percent for multi-sectors. More than 80 percent of the loan projects are located in the central and western provinces compared to about 59 percent during 1986-2004.

5. The ADB's lending program will continue to be supported by technical assistance. The annual nonlending program amounts to around $\$ 11$ million for the period 2005-2007. TAs for operational support cover: (a) transport, (b) energy, (c) land management, (d) water supply and wastewater treatment, (e) urban development, (f) education and health, and (g) environment. TAs for policy impacts and knowledge-based products fall into the following areas: (a) poverty reduction for policy reform and deepening the impact of ADB lending projects, (b) financial sector reform, (c) law and development, (d) social security reform, and (e) fiscal reform.

6. Overall, China has demonstrated strong project implementation capability. The good performance reflects the strong sense of project ownership among agencies involved in the design, implementation, and management of projects, as well as the rigorous screening process for development projects, particularly those proposed for external assistance. Loan disbursement and contract award performance is good. 
Table VI.1: ADB Distribution of Lending (Public Sector) (In millions of U.S. dollars; as of 31 December 2004)

\begin{tabular}{|l|rr|rr|}
\hline \multirow{2}{*}{ Sector } & Amount & Percentage & No. of Loans & Percentage \\
& & & & \\
Agriculture and Natural & & & & \\
$\quad$ Resources & 1,257 & 8.6 & 15 & 14.0 \\
Energy & $2,184.7$ & 14.8 & 19 & 17.8 \\
Industry and Finance & $1,216.8$ & 8.3 & 11 & 10.3 \\
Transport and Communications & $8,254.5$ & 56.1 & 48 & 44.9 \\
Social Infrastructure & $1,085.36$ & 7.4 & 9 & 8.4 \\
Others & 703.0 & 4.8 & 5 & 4.6 \\
\hline \multicolumn{1}{|c}{ Total } & $14,701.38$ & 100 & 107 & 100 \\
\hline
\end{tabular}

Table VI.2. China: AsDB's Commitments and Disbursements, 1993-2004 (In millions of U.S. dollars)

\begin{tabular}{lrr}
\hline Year & Commitments 1/ & Disbursements 2/ \\
\hline 1993 & 1,031 & 421 \\
1994 & 1,618 & 492 \\
1995 & 2,304 & 558 \\
1996 & 3,282 & 707 \\
1997 & 4,033 & 715 \\
1998 & 4,518 & 831 \\
1999 & 5,337 & 819 \\
2000 & 6,159 & 848 \\
2001 & 6,748 & 1,042 \\
2002 & 7,563 & 782 \\
2003 & 8,075 & 705 \\
\hline 2004 & 8,733 & 636 \\
\hline
\end{tabular}

$1 /$ Refers to cumulative contract awards.

2/ Refers to disbursements for the year. 
China: Millennium Development Goals

(In percent, unless otherwise specified)

\begin{tabular}{|c|c|c|c|c|}
\hline & 1990 & 1995 & 2001 & 2002 \\
\hline 1 Eradicate extreme poverty and hunger & \multicolumn{4}{|c|}{2015 target $=$ halve $1990 \$ 1$ a day poverty and malnutrition rates } \\
\hline Population below US\$1 a day & $\ldots$ & $\ldots$ & 16.1 & $\ldots$ \\
\hline Poverty gap at US\$1 a day & $\ldots$ & $\ldots$ & 3.7 & $\ldots$ \\
\hline Share of income or consumption held by poorest 20 percent & $\ldots$ & $\ldots$ & $\ldots$ & $\ldots$ \\
\hline Prevalence of child malnutrition (percent of children under 5) & 17.4 & 12.9 & 10.0 & $\ldots$ \\
\hline Share of population below minimum level of dietary energy consumption & 16.0 & $\ldots$ & 9.0 & $\ldots$ \\
\hline 2 Achieve universal primary education & \multicolumn{4}{|c|}{2015 target $=$ net enrollment to 100} \\
\hline Net primary enrollment ratio (percent of relevant age group) & 97.4 & 97.9 & 93.2 & $\ldots$ \\
\hline Percentage of cohort reaching grade 5 & 86.0 & 93.8 & $\ldots$ & $\ldots$ \\
\hline Youth literacy rate (ages 15-24) & 95.3 & 96.5 & 97.9 & 98.1 \\
\hline 3 Promote gender equality & \multicolumn{4}{|c|}{2005 target $=$ education ratio to 100} \\
\hline Ratio of girls to boys in primary and secondary education & 81.1 & 87.3 & 97.6 & $\ldots$ \\
\hline Ratio of young literate females to males (ages 15-24) & 95.5 & 97.0 & 98.1 & 98.2 \\
\hline Share of women employed in the nonagricultural sector & $\ldots$ & $\ldots$ & $\ldots$ & $\ldots$ \\
\hline Proportion of seats held by women in national parliament & 21.0 & 21.0 & 22.0 & 22.0 \\
\hline 4 Reduce child mortality & \multicolumn{4}{|c|}{2015 target $=$ reduce 1990 under 5 mortality by two-thirds } \\
\hline Under 5 mortality rate (per 1,000 ) & 49.0 & 46.0 & 39.0 & 36.4 \\
\hline Infant mortality rate (per 1,000 live births) & 38.0 & 37.0 & 31.0 & 30.0 \\
\hline Immunization, measles (percent of children under 12 months) & 98.0 & 93.0 & 79.0 & $\ldots$ \\
\hline 5 Improve maternal health & \multicolumn{4}{|c|}{2015 target $=$ reduce 1990 maternal mortality by three-fourths } \\
\hline Maternal mortality ratio (modeled estimate, per 100,000 live births) & $\ldots$ & 60.0 & $\ldots$ & $\ldots$ \\
\hline Births attended by skilled health staff (percent of total) & 50.3 & $\ldots$ & 70.0 & $\ldots$ \\
\hline 6 Combat HIV/AIDS, malaria and other diseases & \multicolumn{4}{|c|}{2015 target $=$ halt, and begin to reverse, AIDS, etc. } \\
\hline Prevalence of HIV, female (ages 15-24) & $\ldots$ & $\ldots$ & 0.1 & $\ldots$ \\
\hline Contraceptive prevalence rate (of women ages 15-49) & 84.6 & 90.4 & 83.0 & $\ldots$ \\
\hline Number of children orphaned by HIV/AIDS & $\ldots$ & $\ldots$ & 76,000 & $\ldots$ \\
\hline Incidence of tuberculosis (per 100,000 people) & $\ldots$ & $\ldots$ & 107.0 & $\ldots$ \\
\hline Tuberculosis cases detected under DOTS & $\ldots$ & 16.0 & 33.0 & $\ldots$ \\
\hline 7 Ensure environmental sustainability & \multicolumn{4}{|c|}{2015 target $=$ various $1 /$} \\
\hline Forest area ( $\%$ of total land area) & 15.6 & $\ldots$ & 17.0 & $\ldots$ \\
\hline Nationally protected areas (percent of total land area) & $\ldots$ & 6.4 & 6.4 & 7.8 \\
\hline GDP per unit of energy use (PPP \$ per kg oil equivalent) & 1.7 & 2.9 & 4.2 & $\ldots$ \\
\hline $\mathrm{CO} 2$ emissions (metric tons per capita) & 2.1 & 2.6 & 2.3 & $\ldots$ \\
\hline Access to an improved water source (percent of population) & 71.0 & $\ldots$ & 75.0 & $\ldots$ \\
\hline Access to improved sanitation (percent of population) & 29.0 & $\ldots$ & 38.0 & $\ldots$ \\
\hline 8 Develop a Global Partnership for Development & \multicolumn{4}{|c|}{2015 target $=$ various $2 /$} \\
\hline Youth unemployment rate (percent of total labor force ages 15-24) & $\ldots$ & 2.9 & 3.1 & $\ldots$ \\
\hline Fixed line and mobile telephones (per 1,000 people) & 5.9 & 35.9 & 247.7 & $\ldots$ \\
\hline Personal computers (per 1,000 people) & 0.4 & 2.3 & 19.0 & $\ldots$ \\
\hline \multicolumn{5}{|l|}{ General indicators } \\
\hline Population (in billions) & 1.1 & 1.2 & 1.3 & 1.3 \\
\hline Gross national income (US\$ trillion) & 0.4 & 0.6 & 1.1 & 1.2 \\
\hline GNI per capita (US\$) & 320 & 520 & 890 & 940 \\
\hline Adult literacy rate (percent of people ages 15 and over) & 78.3 & 81.9 & 85.8 & 86.4 \\
\hline Total fertility rate (births per woman) & 2.1 & 1.9 & 1.9 & 1.9 \\
\hline Life expectancy at birth (years) & 68.9 & 69.4 & 70.5 & 70.7 \\
\hline
\end{tabular}

Sources: World Development Indicators database, April 2002. In some cases the data are for earlier or later years than those stated. $1 /$ Integrate the principles of sustainable development into country policies and programs and reverse the loss of environmental resources. Halve, by 2015, the proportion of people without sustainable access to safe drinking water. By 2020 , to have achieved a significant improvement in the lives of at least 100 million slum dwellers.

2/Develop further an open, rule-based, predictable, non-discriminatory trading and financial system. Address the Special Needs of the Least Developed Countries. In cooperation with developing countries, develop and implement strategies for decent and productive work for youth. In cooperation with pharmaceutical companies, provide access to affordable, essential drugs. In cooperation with the private sector, make available the benefits of new technologies, especially information and communications. 
INTERNATIONAL MONETARY FUND

\author{
PEOPLE'S REPUBLIC OF CHINA
}

\title{
Staff Report for the 2005 Article IV Consultation
}

\author{
Supplementary Information \\ Prepared by the Staff Representatives for the 2005 Consultation with the \\ People's Republic of China
}

Approved by David Burton and Carlos Muñiz

August 1, 2005

1. This supplement updates recent economic and policy developments since the staff report for the 2005 Article IV consultation (7/8/05) was issued. These developments support the thrust of the staff appraisal. In particular, macroeconomic developments reinforce the need to ensure that investment growth slows sufficiently in the remainder of 2005, and underscore the importance of fully utilizing the flexibility in the new exchange rate regime to provide more room for monetary policy independence and enhance the government's ability to manage the economy.

\section{Recent economic developments}

2. Recent data indicate that the growth momentum in the economy remains strong. GDP grew by $9 \frac{1}{2}$ percent in the first half of 2005 , with the contribution of net exports remaining large. Growth in real fixed asset investment remains high, and there appears to be continuing strength in consumption, as suggested by retail sales figures. Inflation remains subdued, with the increase in the CPI falling slightly to 1.6 percent (year-on-year) in June, reflecting a further decline in the pace of food price growth.

\section{China's strong trade performance through June contributed to a further}

increase in reserves. The trend of strong export growth and weaker import growth continued, resulting in a trade surplus for the first half of 2005 of $\$ 40$ billion, compared to a $\$ 7$ billion deficit for the same period in 2004 . These figures point to the possibility that the current account surplus for the year could exceed the staff's forecast of 6 percent of GDP. The strong trade performance in June, together with continued capital inflows, contributed to a further increase in international reserves, which reached $\$ 711$ billion by the end of the month (an increase of $\$ 101$ billion in the first half of the year, excluding the $\$ 15$ billion capital injection to the Industrial and Commercial Bank of China in April).

4. Recent monetary and fiscal developments are in line with staff projections. Credit growth in June increased slightly to $13 \frac{1}{4}$ percent (year-on-year), but remains below the 2004 rate of $14 \frac{1}{2}$ percent. Budget revenue through end-June has grown by $13 \frac{1}{2}$ percent (year-on-year), higher than the budgeted annual growth target of 11 percent. 
Underlying revenue growth has been even stronger. Excluding the clearance of arrears and current VAT tax rebates to exporters (which were more than three times the cumulative amount paid in the first half of 2004), tax revenue grew by more than 20 percent. These developments are in line with the staff's expectation that the revenue outturn for 2005 could once again exceed the budgeted projection by a substantial amount.

\section{International rating agencies have recently upgraded their assessment of}

China. Standard and Poor's recently upgraded China's sovereign credit rating to A- from $\mathrm{BBB}+$, citing the government's aggressive restructuring of its financial sector combined with improved profitability of the state-owned enterprises. Likewise, Moody's raised their ratings for major Chinese banks, including BOC, CCB, ICBC, and Bank of Communications, reflecting in part efforts to restructure these banks.

\section{Exchange rate policy developments}

\section{The authorities have made an important move toward greater flexibility of} the exchange rate. On July 21, the People's Bank of China (PBC) announced that the exchange rate of the renminbi against the U.S. dollar would be revalued upward by about 2 percent (from RMB 8.28/US\$ to RMB 8.11/US\$) and the exchange rate regime would be changed to set the renminbi's value with reference to a basket of currencies. The authorities indicated that they will not publish the currencies in the reference basket and their relative weights, and many of the operational details regarding the new arrangement remain unclear at this time. Daily fluctuations in the renminbi-U.S. dollar exchange rate will remain limited, as before, to \pm 0.3 percent around a central rate set by the PBC based on the rate at the market closing on the previous day. Daily fluctuations of the renminbi against non-U.S. currencies will be limited to \pm 1.5 percent. The $\mathrm{PBC}$ indicated that it would adjust the exchange rate trading band as necessary to reflect market developments and financial and economic conditions. At the same time, the official announcement underscored the PBC's responsibility for fostering "macroeconomic and financial stability" and "for maintaining the RMB exchange rate basically stable at an adaptive and equilibrium level." Since July 21, the renminbi has traded in a very narrow range, and remains largely unchanged in relation to its revalued rate against the U.S. dollar. At the market close on August 1, the renminbi-U.S. dollar rate was at RMB 8.1046/US\$.

\section{The staff welcomes this change in the exchange rate regime and encourages} the authorities to fully utilize the scope for flexibility afforded by the new

arrangement. The authorities have stressed that the currency basket is simply a reference and that the value of the renminbi is not being pegged to it. There is room built into the new arrangement that can be used to impart a fair degree of flexibility in the exchange rate, albeit gradually. While it is understandable that the authorities may want to limit volatility in the initial weeks after the adoption of the new arrangement to help domestic market participants adapt to the new regime and to influence market expectations, greater exchange rate flexibility remains in China's best interest. It is key in providing scope for monetary policy independence and enhancing the authorities' ability to manage the economy. 


\section{INTERNATIONAL MONETARY FUND}

Public Information Notice (PIN) No. 05/122

FOR IMMEDIATE RELEASE

September 12, 2005
International Monetary Fund

$70019^{\text {th }}$ Street, NW

Washington, D. C. 20431 USA

\section{IMF Concludes 2005 Article IV Consultation with the People's Republic of China}

On August 3, 2005, the Executive Board of the International Monetary Fund (IMF) concluded the Article IV consultation with the People's Republic of China. ${ }^{1}$

\section{Background}

China's rapid economic growth and integration into the global economy continued apace. GDP grew by $9 \frac{1}{2}$ percent in 2004 and in the first half of 2005 , while its composition shifted as investment growth moderated somewhat and the contribution from net exports increased. Retail sales growth remained robust, suggesting continued strong consumer demand. After peaking at 5.3 percent (year-on-year) in the third quarter of 2004, inflation declined to 1.8 percent in July 2005 , largely due to a reversal of food price increases as agricultural production rose.

The external current account surplus rose to $\$ 69$ billion (41/4 percent of GDP) in 2004, as export growth remained strong throughout the year, while import growth slowed, reflecting some moderation in investment and an increase in the supply of some domestic import substitutes. China's trade balance strengthened further in the first seven months of 2005, with exports increasing by 32 percent (year-on-year), while imports grew by 14 percent. A larger external current account surplus, together with strong capital inflows, led to a further sizable increase in gross official reserves. Reserves increased by $\$ 207$ billion in 2004 and

\footnotetext{
${ }^{1}$ Under Article IV of the IMF's Articles of Agreement, the IMF holds bilateral discussions with members, usually every year. A staff team visits the country, collects economic and financial information, and discusses with officials the country's economic developments and policies. On return to headquarters, the staff prepares a report, which forms the basis for discussion by the Executive Board. At the conclusion of the discussion, the Managing Director, as Chairman of the Board, summarizes the views of Executive Directors, and this summary is transmitted to the country's authorities. This PIN summarizes the views of the Executive Board as expressed during the August 3, 2005 Executive Board discussion based on the staff report.
} 
by a further $\$ 101$ billion in the first half of 2005 (excluding $\$ 15$ billion in reserves used for bank recapitalization), bringing the level at end-June to $\$ 719$ billion. While FDI inflows (mainly from Hong Kong SAR, Korea, and Japan) remained strong, a substantial part of the reserve accumulation over this period was accounted for by net non-FDI capital inflows (including errors and omissions) largely attracted by the prospects of a renminbi appreciation.

During 2004, the authorities took a number of steps to tighten macroeconomic policies. The People's Bank of China (PBC) raised the reserve requirement ratio and short-term relending and rediscount rates, increased bank deposit and lending interest rates, and eliminated the ceiling on lending rates. These measures were supplemented with guidance provided by the PBC and the China Bank Regulatory Commission to influence banks' lending decisions. As a result of these measures, and restrained lending by the three large state-owned banks that have been recapitalized, broad money growth declined to 15.7 percent and loan growth to 13.2 percent by June 2005, down by around 4 and $73 / 4$ percentage points, respectively, from their growth rates in 2003. Nevertheless, considerable liquidity remains in the banking system, reflected in the still high excess reserve ratio and low interbank interest rates. On the fiscal side, the deficit fell to $1 \frac{1}{2} 2$ percent of GDP, about one percentage point of GDP below its targeted level in the 2004 budget and the actual outcome for the deficit in 2003. This was helped by strong revenue overperformance, about half of which was used to finance increases in social expenditure and subsidies and to clear up old government liabilities, including arrears on VAT refunds to exporters.

Real GDP growth is projected to slow slightly during the year and to average around 9 percent in 2005, assuming that appropriate macroeconomic policies will be in place to further slow investment growth. The external current account surplus is expected to increase 2 percentage points to 6 percent of GDP, mainly reflecting strong export growth and lower import growth. Inflation should average around 3 percent in 2005 , as slower food price increases will likely be partially offset by a rise in non-food prices as some of last year's rapid producer price increases is passed through to consumer prices and certain administered prices are raised. A significant risk remains that, as large capital inflows add liquidity to the banking system, macroeconomic policies would need to be tightened further if investment growth rebounded. Protectionist sentiments in some of China's trading partner countries have increased in recent months, particularly after textile exports from China to these countries grew sharply with the end of the quota system. A further intensification of such sentiments could adversely affect exports. Moreover, a disorderly unwinding of global current account imbalances would also threaten China's growth, as economic activity in all countries would likely suffer lingering adverse effects. 
China has continued to implement a broad range of structural reforms. In the banking sector, progress has been made in strengthening supervision and improving bank operations, especially in the three large state-owned commercial banks, which have been recapitalized. State-owned enterprises have become more market oriented and corporate and management restructuring has continued. A number of steps also have been taken in line with China's WTO commitments, including further tariff reductions that lowered the unweighted average tariff rate by half a percentage point to 10 percent in 2005.

\section{Executive Board Assessment}

Executive Directors commended the authorities for the success in sustaining high economic growth rates and for their efforts over the past year to guide the economy toward a soft landing. While recent data suggest that growth has shifted away from investment toward consumption and exports, and inflation has come down, the risk of a rebound in credit growth and investment calls for continued vigilance, given the considerable liquidity already in the banking system. Directors noted that medium-term prospects are generally favorable, although oil price volatility, a disorderly resolution of global imbalances, and trade restrictions against China could pose potential challenges for the authorities. They stressed that appropriate policy responses and continued implementation of structural reform, particularly in the financial sector, public finances, and the labor market, will help establish a solid foundation for China's further integration into the global economy and improve living standards and income distribution across regions.

In view of the need to ensure that the pace of investment and credit growth remains in check, Directors generally considered that steps should be taken to drain more of the excess liquidity out of the banking system through open market operations. Moreover, the authorities should stand ready to take other policy actions, including increases in interest rates and reserve requirements, if investment and lending show signs of resurgence. A few Directors recommended a cautious approach to further tightening, particularly given evidence of excess capacity in certain sectors. Directors also noted that the effectiveness of monetary policy would be greatly enhanced by granting the People's Bank of China (PBC) more discretion over interest rate policy. They recognized that administrative measures remain necessary and effective for curbing credit growth in certain sectors, given the stage of China's financial sector development. Nevertheless, Directors called on the authorities to gradually increase reliance on market-based instruments. Enhanced supervision of bank lending and strengthened prudential rules should also help keep near-term credit growth in check and enhance overall financial stability.

Directors noted that the widening current account surplus over the past two years, combined with continued strong capital inflows, has led to a large build-up in international reserves and has complicated the conduct of monetary policy. Against this background, Directors welcomed the change in the exchange rate regime-an important move toward greater exchange rate flexibility —and encouraged the authorities to utilize the flexibility afforded by the new arrangement. Noting the difficulty in assessing with a reasonable degree of confidence the "equilibrium" exchange rate for China, they agreed that a more flexible exchange rate, not simply a revaluation, is key to providing scope for monetary policy independence and enhancing the economy's resilience to external shocks. Going forward, many Directors supported a gradual, cautious approach to further increasing exchange rate flexibility, in order to coordinate such steps with financial sector reforms and capital account 
liberalization, and to allow time for the economy to adjust and for market-based instruments to be developed further. However, a number of other Directors recommended that the authorities allow the exchange rate to move more quickly toward a level that better reflects underlying market forces.

Directors emphasized that greater exchange rate flexibility is in China's best interest. They also considered that, as correcting global imbalances is a responsibility of all the major countries, China's move toward greater exchange rate flexibility would contribute directly to that process, as well as indirectly by facilitating greater exchange rate adjustments in other Asian countries.

Directors agreed that the likely outturn of the 2005 budget is broadly appropriate. They welcomed in particular the shift in expenditure from investment to social spending, and urged further reallocation in this direction to help constrain investment growth while increasing much needed spending on health and education. Directors encouraged the authorities to save any revenue overperformance that accrues to the central government, thereby helping to restrain domestic demand.

Directors supported the authorities' aim to continue fiscal consolidation over the medium term in order to keep debt at sustainable levels while meeting growing demands on public funds, including potentially large contingent liabilities. Most Directors encouraged further significant cuts in the nominal deficit target when conditions permit, and saw scope for such a reduction in the 2006 budget, on the expectation that revenue would continue to overperform relative to the budget projection and that all outstanding arrears on VAT refunds would be cleared in 2005. A few Directors cautioned that the need for further fiscal consolidation should be weighed against China's large infrastructure and social spending needs.

Directors emphasized that fiscal consolidation should be accompanied by strengthening the structure of the public finances, reforming the tax system, and addressing structural imbalances in subnational finances, including by clarifying expenditure responsibilities and reforming the transfer system to move toward a more rule-based equalization system. The central government should also make adequate resources available to local governments to fund existing pension and other social liabilities. Fiscal management should be strengthened further, particularly by adopting a revised budget classification system and expanding the coverage of the treasury single account.

Directors welcomed the focus being placed on financial sector restructuring to improve intermediation of China's large private savings. They welcomed in particular the progress made in three of the four large state-owned commercial banks, and urged that a restructuring plan be formulated for the Agricultural Bank to ensure the health of the banking system. Directors emphasized the need for all banks to strengthen their balance sheets, and improve their commercial orientation, risk management, internal controls, and governance. They welcomed the liberalization of lending rates, which was an important step taken by the PBC to help develop the banking sector and encourage banks to improve the pricing of risk. Further efforts are needed to eliminate the involvement of government in bank management and business operations. Diversifying bank ownership could bring much needed technical expertise and enhance governance. 
Directors commended the China Bank Regulatory Commission for the progress in improving bank supervision. Further efforts will be needed to ensure that all banks can comply with capital adequacy requirements with full provisioning as required by existing guidelines. Directors stressed that the adoption of a new bankruptcy law that provides sufficient protection to creditors and allows for an adequate market mechanism to facilitate liquidation will be important for resolving existing and future non-performing loans in an orderly manner. Directors welcomed China's decision to participate in an FSAP and looked forward to an early assessment. They welcomed the authorities' commitment to curb money laundering and combat the financing of terrorism, and looked forward to the enactment of comprehensive legislation that is consistent with the core recommendations of the Financial Action Task Force.

Directors supported the plans to accelerate the development of bond and equity markets. They noted that a key first step would be to eliminate the current system of government approval for corporate bond issuance, and replace it with a more market-oriented system based on disclosure of operational and financial information for issuing firms. In addition, removing the cap on corporate bond interest rates would allow proper pricing of such bonds. It is also important to limit the use of public resources to protect investors, which could lead to moral hazard.

Directors observed that state-owned enterprises (SOEs) have become more market oriented, with corporate and management restructuring and increased foreign ownership. Nevertheless, additional reforms are still needed to ensure their long-term viability. Directors urged the government to exercise stronger governance over the SOEs. Strengthening the ownership role of the State Asset Supervision and Administration Commission and requiring profitable SOEs to pay dividends to the government are essential to focus enterprises more on increasing their net worth.

Directors welcomed improvements in the quality of economic statistics, but noted that incomplete data in several areas still hamper the monitoring of macroeconomic developments. A continuing priority for further improvement is the compilation and timely publication of annual and quarterly real GDP data on an expenditure basis. Directors encouraged the authorities to make full use of Fund technical assistance to improve balance of payments statistics and ensure that the reporting of data on the international investment position is completed as soon as feasible.

Public Information Notices (PINs) form part of the IMF's efforts to promote transparency of the IMF's views and analysis of economic developments and policies. With the consent of the country (or countries) concerned, PINs are issued after Executive Board discussions of Article IV consultations with member countries, of its surveillance of developments at the regional level, of post-program monitoring, and of ex post assessments of member countries with longer-term program engagements. PINs are also issued after Executive Board discussions of general policy matters, unless otherwise decided by the Executive Board in a particular case. 
People's Republic of China: Selected Economic and Financial Indicators 1/

$2001 \quad 2002 \quad 2003 \quad 2004 \begin{array}{r}\begin{array}{r}2005 \\ \text { IMF Staff } \\ \text { Projections }\end{array} \\ \hline\end{array}$

\section{Domestic economy}

$\begin{array}{llllll}\text { Real GDP } & 7.5 & 8.3 & 9.5 & 9.5 & 9.0 \\ \text { Consumer prices (period average) } & 0.7 & -0.8 & 1.2 & 3.9 & 3.0\end{array}$

\section{External economy}

Exports

$\begin{array}{rrrrr}266 & 326 & 438 & 593 & 750 \\ -232 & -281 & -394 & -534 & -654 \\ 17 & 35 & 46 & 69 & 114 \\ 35 & 32 & 53 & 111 & 96 \\ 37 & 47 & 47 & 53 & 55 \\ 219 & 295 & 412 & 619 & 829 \\ 1.5 & 2.8 & 3.2 & 4.2 & 6.0\end{array}$

Imports

(In billions of U.S. dollars)

Current account balance

Capital and financial account balance 2/

(Change in percent)

Of which: Direct investment, net

(In percent of GDP)

Public finance 4/

Overall budgetary balance

$-3.1$

$-3.4$

$-2.8$

$-1.7$

Revenue

17.0

18.2

18.7

19.4

18.8

Expenditure

20.1

21.6

21.5

21.1

20.9

(Change in percent)

\section{Money and interest rates}

Broad money (M2) 5/

Sources: Chinese authorities; and IMF staff estimates.

1/ As of June 21, 2005.

2/ Excluding errors and omissions.

$3 /$ Includes gold, SDR holdings, and reserve position in the Fund.

4/ Central and local governments. The 2005 figures reflect official budget data.

5/ Banking survey.

6/ One-year time deposits, year-end. 